\title{
Indium(III)-Catalyzed Stereoselective Synthesis of Tricyclic Frameworks by Cascade Cycloisomerization Reactions of Aryl 1,5- Enynes
}

\author{
Ramón E. Millán, Jaime Rodríguez, Luis A. Sarandeses, Enrique Gómez-Bengoa,* \\ and José Pérez Sestelo*
}

Cite This: J. Org. Chem. 2021, 86, 9515-9529

Read Online

ABSTRACT: The indium(III)-catalyzed cascade cycloisomerization reaction of 1,5-enynes with pendant aryl nucleophiles is reported. The reaction proceeds in cascade under mild reaction conditions, using $\operatorname{InI}_{3}(5 \mathrm{~mol} \%)$ as a catalyst with a range of 1,5enynes furnished with aryl groups (phenyl and phenol) at alkene ( $E$ and $\mathrm{Z}$ isomers) and with terminal and internal alkynes. Using 1bromo-1,5-enynes, a one-pot sequential indium-catalyzed cycloisomerization and palladium-catalyzed cross-coupling with triorganoindium reagents were developed. The double cyclization is stereospecific and operates via a biomimetic cascade cation-olefin through 1,5-enyne cyclization (6-endo-dig) and subsequent $\mathrm{C}-\mathrm{C}$

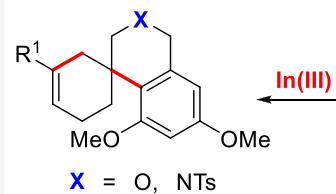

$X=O, N T s$
$R^{1}=H, P h, B r$

$\mathbf{R}^{2}=\mathrm{Me}, \mathrm{CH}_{2} \mathbf{X C H}_{2} \mathbf{A r}$ $\mathbf{R}^{3}=\mathrm{CH}_{2} \mathbf{X A r}, \mathrm{CH}_{2}$ ArOH, $\mathrm{H}$
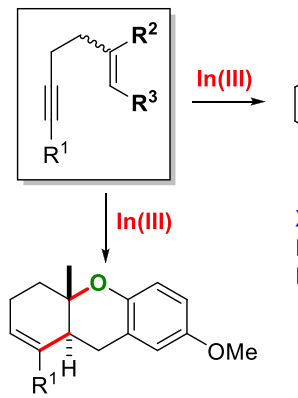

$\mathrm{R}^{1}=\mathrm{H}, \mathrm{Me}, n-\mathrm{Bu}, \mathrm{Ph}, \mathrm{Br}$

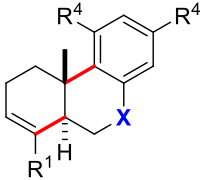

$X=O, \quad N T s$ $\mathrm{R}^{1}=\mathrm{H}, \mathrm{Me}, \mathrm{Ph}, \mathrm{Br}$ $\mathrm{R}^{4}=\mathrm{H}, \mathrm{OMe}$ hydroarylation or $\mathrm{C}-\mathrm{O}$ phenoxycyclization. Density functional theory (DFT) computational studies on 1,5-enynyl aryl ethers support a two-step mechanism where the first stereoselective 1,5-enyne cyclization produces a nonclassical carbocation intermediate that evolves to the tricyclic reaction product through a $S_{\mathrm{E}} A r$ mechanism. Using this approach, a variety of tricyclic heterocycles such as benzo $[b]$ chromenes, phenanthridines, xanthenes, and spiroheterocyclic compounds are efficiently synthesized with high atom economy.

\section{INTRODUCTION}

The design of synthetic methodologies based on catalytic cascade reactions constitutes an ideal tool for the construction of complex molecules with high chemo-, regio-, and stereoselectivity. ${ }^{1}$ In particular, catalytic cascade cycloisomerization reactions allow the synthesis of a large structural diversity of molecules under complete atom economy and mild reaction conditions. As an example, cascade polyene cyclizations are one of the most impressive biosynthetic transformations known, and their chemical emulation represents a major challenge in modern synthetic chemistry. ${ }^{2}$ Usually, these transformations involve the epoxide activation in a polyenic compound using oxophilic Lewis acids under stoichiometric or catalytic conditions. ${ }^{3}$ Alternatively, electrophilic alkyne activation under metal catalysis has been recently envisaged as a different synthetic approach to promote catalytic cascade polyenynic $\pi$ cyclizations. ${ }^{4}$ The catalytic electrophilic activation of alkynes promotes the addition of nucleophiles and allows the formation of new carbon-carbon and carbon-heteroatom bonds in an intermolecular and intramolecular manner. Although this methodology has been associated with the use of carbophilic late precious transition metals such as platinum ${ }^{5}$ or gold $^{6}$ as catalysts, main group metals such as gallium ${ }^{7}$ or indium ${ }^{8}$ have been shown as valuable alternatives (Scheme 1a).
Indium(III) is a soft Lewis acid that exhibits a dual-mode catalytic activity as $\sigma$-acid and $\pi$-acid, enabling both the electrophilic activation of carbon-heteroatom and to carboncarbon unsaturated bonds. ${ }^{9}$ In addition, reactions involving indium are used to provide high chemoselectivity and substantial economical, environmental, and safety advantages. ${ }^{10}$ Along the years, these attractive chemical properties have been exploited in classical synthetic transformations as oxophilic Lewis acid either by using stoichiometric or catalytic conditions. ${ }^{11}$ Recent contributions have demonstrated the synthetic utility of indium(III) salts as carbophilic $\pi$-acid catalysts in the electrophilic activation of alkynes. ${ }^{12}$

Metal-catalyzed 1,n-enyne cycloisomerization reactions constitute a straightforward methodology for the synthesis of polycyclic structures. ${ }^{13}$ In particular, gold(I)-catalyzed cycloisomerization reactions of functionalized 1,5- and 1,6-enynes

Received: April 9, 2021

Published: June 25, 2021 
Scheme 1. Indium(III)-Catalyzed Electrophilic Activation of Alkynes

(a) Indium-catalyzed electrophilic activation of alkynes

$$
\stackrel{\mathrm{NuH}}{\longrightarrow}\left[\mathrm{R}_{+\mathrm{NuH}}^{\mathrm{R}_{3} \ln } \mathrm{R}_{\mathrm{R}_{2}}^{\mathrm{R}_{1}} \stackrel{-\ln \mathrm{X}_{3}}{\longrightarrow} \mathrm{R}_{\mathrm{Nu}}^{\ln \mathrm{X}_{3}}\right.
$$

(b) Indium-catalyzed polyyne cycloisomerization

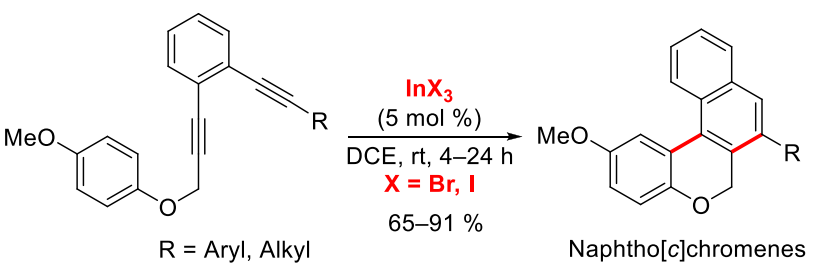

(c) This work

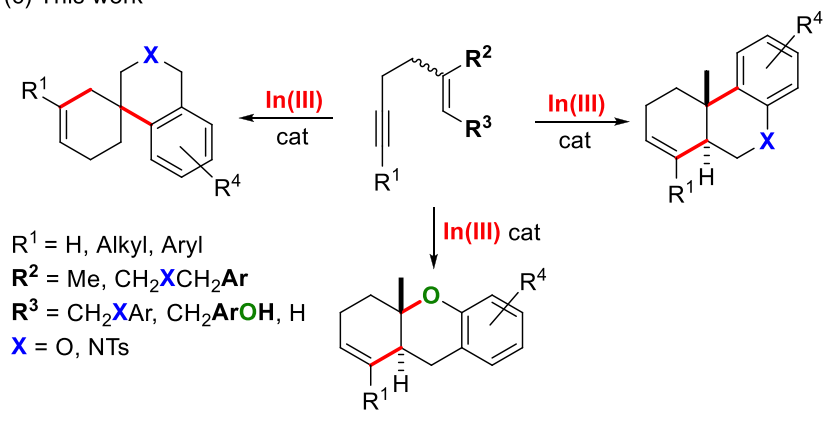

have been widely explored for the synthesis of polycyclic organic compounds. ${ }^{14}$ On the other hand, indium(III)-catalyzed enyne cycloisomerization reactions were first reported by Chatani, ${ }^{15}$ and more recently, Corey described the stereoselective synthesis of complex chiral polycyclic molecules by cascade cycloisomerization of chiral aryl polyenynes under indium(III) catalysis. ${ }^{16 a}$ In this contribution, the catalytic activity of In(III) as $\pi$-acid for the electrophilic activation of alkynes is remarked and attributed to the vacant $5 \mathrm{~s}$ and $5 \mathrm{p}$ orbitals, which might lead to coordinate the $\mathrm{C}-\mathrm{C}$ triple bond by bidentate complexation. Later on, Corey also reported the superior catalytic activity of diiodoindium(III) cation $\left(\mathrm{InI}_{2}^{+}\right)$, generated by the addition of $\mathrm{Ag}(\mathrm{I})$ salts to $\mathrm{InI}_{3}$. ${ }^{16 \mathrm{~b}}$

As part of a long-term research on indium chemistry, ${ }^{17}$ our group has recently reported intramolecular hydroarylation and hydroalkoxylation reactions and sequential indium-catalyzed polyyne reactions under indium(III) catalysis (Scheme $1 \mathrm{~b}) .^{18}$ Herein, we report the In(III)-catalyzed cascade cycloisomerization reactions of 1,5-enynes ( $E$ and $Z$ isomers) furnished with aryl nucleophiles and density functional theory (DFT) studies about the mechanism of the reaction and the nature of the organoindium intermediates involved (Scheme 1c).

\section{RESULTS AND DISCUSSION}

Our investigation started with the cycloisomerization reaction of (E)-1,5-enynyl aryl ether 1a under In(III) catalysis. This substrate was chosen to measure the indium alkynophilicity, the regioselectivity of the reaction (6-endo vs 5-exo), and to establish comparisons with other metal catalysts. ${ }^{14 a}$ In our first experiments, we found that the treatment of $(E)$-1 a with $5 \mathrm{~mol} \%$ $\mathrm{InI}_{3}$ in 1,2-dichloroethane (DCE) at $60{ }^{\circ} \mathrm{C}$ resulted in the stereoselective formation of the tricyclic compound $2 \mathrm{a}$ in $58 \%$ yield after $5 \mathrm{~h}$ as the only isolated product as a separable mixture of diastereoisomers (cis/trans $=25: 75$, Table 1 , entry 1 ).
Table 1. Indium-Catalyzed Reactions with $(E)-1,3-$ Dimethoxy-5-[(3-methylhept-2-en-6-yn-1-yl)oxy] benzene (1a)<smiles>C#CCCC1=CCOc2cc(OC)cc(OC)c21</smiles>

$1 a$

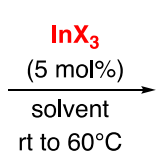

rt to $60^{\circ} \mathrm{C}$<smiles>COc1cc(OC)c2c(c1)OC[C@@H]1C=CCCC21C</smiles>

2a

\begin{tabular}{clllllc} 
entry & \multicolumn{1}{c}{$\mathrm{InX}_{3}$} & solvent & $\begin{array}{c}T \\
\left({ }^{\circ} \mathrm{C}\right)\end{array}$ & $\begin{array}{c}t \\
(\mathrm{~h})^{a}\end{array}$ & $\begin{array}{c}\text { yield } \\
(\%)^{b}\end{array}$ & $\begin{array}{c}\text { 2a } \\
(\text { cis/trans })^{c}\end{array}$ \\
1 & $\mathrm{InI}_{3}$ & DCE & 60 & 5 & 58 & $25: 75$ \\
2 & $\mathrm{InBr}_{3}$ & DCE & 60 & 20 & 53 & $33: 67$ \\
3 & $\mathrm{InCl}_{3}$ & DCE & 60 & 48 & $d$ & \\
4 & $\mathrm{InI}_{3}{ }^{e}$ & DCE & 60 & 24 & 55 & $31: 69$ \\
5 & $\mathrm{InI}_{3}$ & toluene & 60 & 2 & 65 & $11: 89$ \\
6 & $\mathrm{InI}_{3}^{f}$ & toluene & $\mathrm{rt}$ & 6 & 62 & $20: 80$ \\
7 & $\mathrm{InI}_{3}^{f}$ & DCM & $\mathrm{rt}$ & 7 & 63 & $19: 81$ \\
8 & $\mathrm{InI}_{3}^{f}$ & DCM & -20 & 24 & $d$ & \\
9 & $\mathrm{InI}_{3}^{g}$ & DCE & 60 & 5 & $72^{h}$ & \\
10 & $\mathrm{In}\left(\mathrm{NTf}_{2}\right)_{3}$ & DCE & 60 & 5 & $63^{i}$ & \\
11 & ${\mathrm{In}(\mathrm{OTf})_{3}}_{12}$ & DCE & 60 & 24 & $j$ & \\
12 & $\mathrm{In}(\mathrm{acac})_{3}$ & DCE & 60 & 48 & $d$ &
\end{tabular}

${ }^{a}$ Monitored by thin-layer chromatography (TLC). ${ }^{b}$ Isolated yield. ${ }^{c}$ Determined by gas chromatography-mass spectrometry (GCMS). ${ }^{d}$ No reaction observed. ${ }^{e} 2 \mathrm{~mol} \% .{ }^{f_{2}} \mathrm{~mol}{ }{ }^{g}{ }^{g} \mathrm{AgSbF}_{6}(5 \mathrm{~mol} \%)$ as a cocatalyst. ${ }^{h}$ Mixture of products I:2a (4:1 ratio). ${ }^{i}$ Compound II was isolated. ${ }^{j}$ Decomposition.
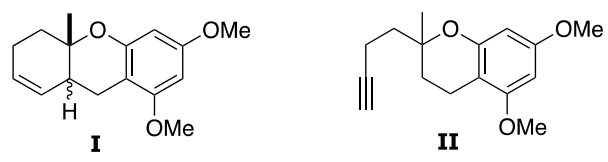

Alternatively, the use of $\operatorname{InBr}_{3}(5 \mathrm{~mol} \%)$ also provided $2 \mathbf{a}$ in similar yield and diastereoselectivity, whilst $\operatorname{InCl}_{3}(5 \mathrm{~mol} \%)$ resulted to be ineffective (entries 2 and 3, respectively). In all cases, trans-fused $2 \mathrm{a}$ was identified as the major diastereoisomer and its formation can be explained by a double regioselective 6endo-dig/endo-trig cyclization in cascade.

The stereoselectivity of this In(III)-catalyzed 1,5-enyne cycloisomerization was then studied under different reaction conditions. In this endeavor, we found that the reaction also takes place with $2 \mathrm{~mol} \%$ of $\mathrm{InI}_{3}$ in similar stereoselectivity but longer reaction times $(55 \%$, cis/trans $=31: 69$, entry 4$)$. Interestingly, the yield, stereoselectivity, and reaction time were slightly improved using toluene as a solvent $(65 \%$, cis/trans $=11: 89$, entry 5). The reaction also proceeds at room temperature using $20 \mathrm{~mol} \%$ of $\mathrm{InI}_{3}$ in toluene or dichloromethane (DCM) with similar results (entries 6 and 7), but no reaction was observed at $-20{ }^{\circ} \mathrm{C}$ (entry 8). Surprisingly, the combination of $\operatorname{InI}_{3}(5 \mathrm{~mol} \%)$ with the halide abstractor $\mathrm{AgSbF}_{6}$ $(5 \mathrm{~mol} \%)$ to generate the diiodonium cation $\left(\mathrm{InI}_{2}^{+}\right)$gave a new major tricyclic product (I) concomitant with $2 \mathbf{a}$ (I:2a $=4: 1$ ratio) as a separable mixture in a combined $72 \%$ isolated yield (entry 9). The formation of compound I, as a mixture of cis/trans (11:89) diastereoisomers, can be explained by ether cleavage, Friedel-Crafts $C$-alkylation, and 1,5-enyne phenoxycyclization reaction. In a similar pathway, treatment with $\operatorname{In}\left(\mathrm{NTf}_{2}\right)_{3}(5 \mathrm{~mol}$ $\%)$ resulted in the formation of the bicyclic compound II (63\% yield, entry 10) with an alkene phenoxycyclization as the last step. The use of $\operatorname{In}(\mathrm{OTf})_{3}$ as a catalyst resulted in decomposition (entry 11). No reaction was observed employing $\operatorname{In}(\mathrm{acac})_{3}$ as the catalyst, recovering the starting 1,5-enyne 1a (entry 12). In 
this optimization process, the important role of the catalyst counteranion is noteworthy, confirming $\mathrm{InI}_{3}$ as the most efficient $\pi$-catalyst. Although different solvents can be used, toluene was the solvent of choice for this 1,5-enyne cyclization. The high chemoselectivity of $\mathrm{InI}_{3}$ in the electrophilic activation of the alkyne over the ether cleavage is remarkable.

To further study the chemo-, regio-, and stereoselectivity and access to novel functionalized benzo $[b]$ chromenes, our investigation was extended to 1,5-enynes functionalized at the arene and alkyne units and with different alkene geometries. Under the previously optimized reaction conditions, we were pleased to find that the reaction of 1,5-enyne $(E)$-1b furnished with a methyl group at the terminal alkyne proceeded successfully to give trans-2b in $68 \%$ yield as a separable diastereoisomeric mixture (cis/trans $=22: 78$, Table 2, entry 2 ). This synthetic transformation was more efficient and selective than using $\mathrm{Hg}$ (II), probably due to the softer Lewis acid character of In(III). ${ }^{14 a}$ Interestingly, the reaction using 1bromo-1,5-enyne (E)-1c also provided 7-bromobenzo[b]chromene trans-2c diastereoselectively in good yield (62\%, cis/trans $=27: 73$, entry 3$)$. The synthesis of trans-2c should allow access to a variety of substituted benzo $[b]$ chromenes by metal-catalyzed cross-coupling reactions. ${ }^{17}$

The role of electronic effects was examined using phenyl 1,5enynyl ether (E)-1d. Interestingly, under the previously developed reaction conditions, the double cycloisomerization proceeded with complete stereochemical inversion giving rise to the cis-benzo[ $b]$ chromene cis-2d as a single diastereoisomer by ${ }^{1} \mathrm{H}$ NMR (61\% yield, Table 2, entry 4). The isomerization suggests a two-step mechanism, where the lower nucleophilicity of the phenyl group facilitates the stereochemical inversion after the first 6-endo-dig cycloisomerization reaction to produce the most thermodynamically stable diastereoisomer.

Prompted by these interesting results, we studied the influence of alkene stereochemistry on the reactivity, regio-, and stereoselectivity. Previous metal-catalyzed 1,5-enyne cycloisomerization reactions have shown a divergent outcome based on the alkene geometry. ${ }^{14 c}$ In our case, the In(III)-catalyzed cycloisomerization with ( $Z$ )-1a also proceeded with 6-endo regioselectivity without isomerization providing the cis-2a as a single diastereoisomer as determined by ${ }^{1} \mathrm{H}$ NMR in $64 \%$ yield (Table 2, entry 5). The same regiochemistry and stereochemical outcomes were observed using 1-bromo-1,5-enyne $(Z)$-1c (entry 6). Interestingly, the reaction with 1,5-enyne $(Z)-1 d$ also proceeded with full retention of the stereochemistry to obtain cis-2d as the only diastereoisomer as established by ${ }^{1} \mathrm{H}$ NMR (entry 7). These results point out at least three reactivity patterns: the reaction is stereospecific through a two-step mechanism; electronic effects affect the stereochemical outcome; and the cis stereoisomer is thermodynamically more favorable.

After these interesting results, we explored the reaction with 1,5-enynyl phenyl $N$-tosylamines, substrates of interest for the synthesis of nitrogen heterocycles such as phenanthridines or indoles. In this venture, we found that the reaction of 3,5dimethoxyphenyl 1,5-enynyl $N$-tosylamine $(E)$-3a with $\operatorname{InI}_{3}(5$ $\mathrm{mol} \%)$ in toluene at $60^{\circ} \mathrm{C}$ gave the phenanthridine trans-4a in $90 \%$ yield in just $2 \mathrm{~h}$ as the only diastereoisomer detected by ${ }^{1} \mathrm{H}$ NMR (Table 3, entry 1). Analogously, the reaction with 1,5enynes $(E)-\mathbf{3 b}$ and $(E)-\mathbf{3} \mathbf{c}$ furnished with a methyl and a phenyl group at the alkyne afforded phenanthridines trans- $\mathbf{4 b}$ and trans$4 \mathrm{c}$ stereoselectively as the only isolated products in 85 and $82 \%$ yield (Table 3, entries 2 and 3, respectively). Furthermore, the

Table 2. Indium-Catalyzed Reactions with 1,5-Enynyl Aryl Ethers $1 a-d^{c}$<smiles>[R]C#CCCC1=CCOc2cc([R])cc([R])c21</smiles><smiles>CCCC1=CCOc2cc(OC)cc(OC)c21</smiles>
$(E)-\mathbf{a}$ Product $^{\mathrm{a}}$ Yield $(\%)^{\mathrm{b}}$ cis:trans $^{\mathrm{c}}$<smiles>COc1cc(OC)c2c(c1)OC[C@H]1C=CCCC21C</smiles><smiles>CC#CCCC1=CCOc2cc(OC)cc(OC)c21</smiles><smiles>COc1cc(OC)c2c(c1)OCC=C2CCC#CBr</smiles><smiles>C#CCCC1=CCOc2ccccc21</smiles>

$(E)-1 d$

5<smiles>C#CCC/C(C)=C\COc1cc(OC)cc(OC)c1</smiles>

(Z)-1a<smiles>COc1cc(OC)cc(OC/C=C(/C)CCC#CBr)c1</smiles>

(Z)-1c

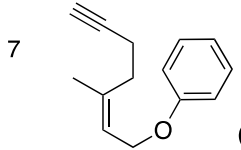

(Z)-1d
68 $22: 78$<smiles>C=C1CC2(CCC=CC2C)COC1=O</smiles>

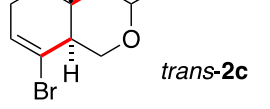<smiles>CC12CCC=C[C@H]1COc1ccccc12</smiles><smiles>COc1cc(OC)c2c(c1)OC[C@H]1C=CCC[C@@]21C</smiles><smiles>COc1cc(O)c2c(c1)OCC1C(Br)=CCCC21C</smiles>

${ }^{a}$ Major isolated diastereomer. ${ }^{b}$ Isolated yield. ${ }^{c}$ Measured by ${ }^{1} \mathrm{H}$ NMR.

reaction with 1-bromo-1,5-enyne $(E)$-3d led to the 7-bromohexahydrophenanthridine trans-4d in $73 \%$ yield (entry 4 ). Although no isomerization was detected with these 1,5-enynes, the reaction of $(E)-1,5$-enyne $3 \mathbf{e}$, furnished with an unsubstituted phenyl group, proceeded with complete inversion and the cis-4e was obtained as a single diastereoisomer (49\% yield, entry 5). As previously reported, the isomerization can be explained by a stepwise mechanism where after the first 6-endodig cyclization, the synthetic intermediate could isomerize toward the most thermodynamically stable polycyclic compound. Therefore, we can conclude that aryl 1,5-enynes $3 \mathbf{a}-\mathbf{d}$ furnished with the $\mathrm{N}$-tosylamine moiety are more reactive than 
Table 3. Indium-Catalyzed Reactions of 1,5-Enynyl Aryl NTosylamines $3 \mathrm{a}-\mathrm{f}$

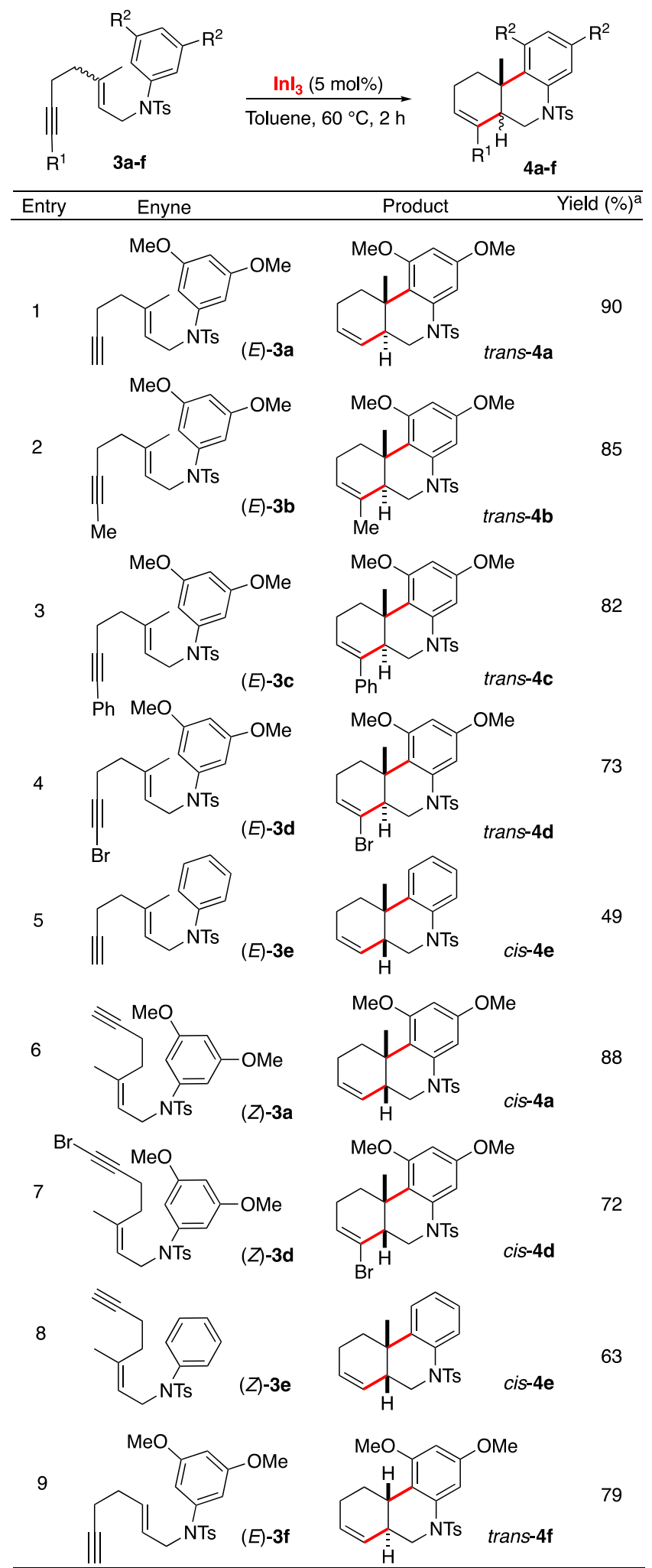

${ }^{a}$ Isolated yield.

the ethers $\mathbf{1 a}-\mathbf{d}$ and the cycloisomerization reaction takes place with complete retention of the alkene configuration.

The stereospecificity of the cycloisomerization reaction was also explored with the $Z$-alkene analogues. In this case, we observed that the reaction with 1,5-enyne ( $Z$ )-3a afforded phenanthridine cis-4a as a single diastereoisomer in $88 \%$ yield (entry 6). Analogously, the reaction with bromoalkyne ( $Z$ )-3d provided phenanthridine cis-4d in $72 \%$ yield (entry 7 ) and the reaction with 1,5-enyne $(Z)$-3e without methoxy groups at the phenyl unit gave cis-4e in $63 \%$ yield (entry 8 ). As previously observed with the 1,5-enynyl ether $(Z)$-1d, in this case, the reaction proceeded with full retention of the alkene stereochemistry. Finally, we also explored the reaction with $(E)-1,5-$ enyne 3f, where the alkene moiety is disubstituted. Gratifyingly, the cascade cycloisomerization proceeded with complete regioand stereospecificity to afford trans- $4 \mathrm{f}$ in $79 \%$ yield as the only detected and isolated product. ${ }^{19}$ This result demonstrates that the cascade cycloisomerization reaction is not limited to trisubstituted alkenes and resembles a biomimetic cascade olefin process.

The synthetic utility of the In(III)-catalyzed double cycloisomerization was then explored using 1,5-enynes equipped with a phenol moiety. Although $\mathrm{InI}_{3}$ showed as an efficient catalyst for the synthesis of benzo[ $b]$ furans from ortho-alkynylphenols, ${ }^{18 \mathrm{~d}}$ this cascade cycloisomerization process found some synthetic limitations using other transition metal catalysts. ${ }^{20}$ In addition, the regioselective phenoxycyclization should provide access to xanthenes, a tricyclic skeleton of a relevant class of natural products. $^{21}$

Using 1,5-enyne (E)-5a as a model substrate, ${ }^{20}$ we found that $\mathrm{InI}_{3}(5 \mathrm{~mol} \%)$ catalyzes the double cycloisomerization reaction in toluene at room temperature to afford the tricyclic 6-endo-dig/ endo-trig product trans-6a in $86 \%$ isolated yield as a single diastereoisomer in $5 \mathrm{~h}$ (Table 4, entry 1 ). It is interesting to note the higher reactivity exhibited compared to the previous aryl 1,5enynyl ethers $\mathbf{1 a}-\mathbf{d}$ and $N$-tosylamines $\mathbf{3 a}-\mathbf{f}$ as well as the chemical compatibility of the In(III) catalysis with the free hydroxyl group of the phenol. Furthermore, the reaction with (Z)-5a provided the cis-fused xanthene cis-6a in an excellent yield of $87 \%$ as the only isolated product (entry 2 ). These experimental results could be explained either by a stereospecific concerted or by a stepwise mechanism.

As the next step, we also tested the reaction of aryl 1,5-enynes 5 substituted at the alkyne. However, the complex synthesis of these substrates led us to consider a sequential procedure based on indium-catalyzed cascade cycloisomerization of the 1bromo-1,5-enyne $(E)-5 \mathbf{b}^{14 c}$ and subsequent functionalization by the cross-coupling reaction. With this approach in mind, we found that the reaction of 1-bromo-1,5-enyne $(E)-5 \mathbf{b}$ and $(Z)$ $5 \mathbf{b}$ with $\mathrm{InI}_{3}(5 \mathrm{~mol} \%)$ results in a stereospecific manner, affording the expected 1-bromo-tetrahydroxanthenes trans-6b and cis-6b in 89 and $92 \%$ yield, respectively, as the only isolated products (Table 4, entries 3 and 4).

Having demonstrated the feasibility of both alkene isomers of 1-bromo-1,5-enyne $\mathbf{5 b}$ in the double cycloisomerization reaction, we assayed the one-pot sequential indium(III)catalyzed 1,5-enyne cyclization and palladium-catalyzed crosscoupling reaction using triorganoindium reagents. ${ }^{17,22}$ Gratifyingly, the treatment of $(E)-5 \mathbf{b}$ with $\mathrm{InI}_{3}(5 \mathrm{~mol} \%)$ in toluene at room temperature followed by addition of a solution of $\mathrm{Ph}_{3} \mathrm{In}$ $(70 \mathrm{~mol} \%)$ and $\mathrm{Pd}\left(\mathrm{PPh}_{3}\right)_{4}(5 \mathrm{~mol} \%)$ in tetrahydrofuran (THF) at $80{ }^{\circ} \mathrm{C}$ afforded the 4-phenyltetrahydroxhantene trans-6c in $76 \%$ yield (Scheme 2 ). The sequential protocol using $\mathrm{Me}_{3} \mathrm{In}$ and $n-\mathrm{Bu}_{3}$ In also gave the xanthene derivatives trans-6d and trans-6e in 83 and $81 \%$ yield, respectively. These results show the versatility of the In-catalyzed cascade cycloisomerization 
Table 4. Indium-Catalyzed Phenoxycyclization of 1,5-Enynes $5 a-b$

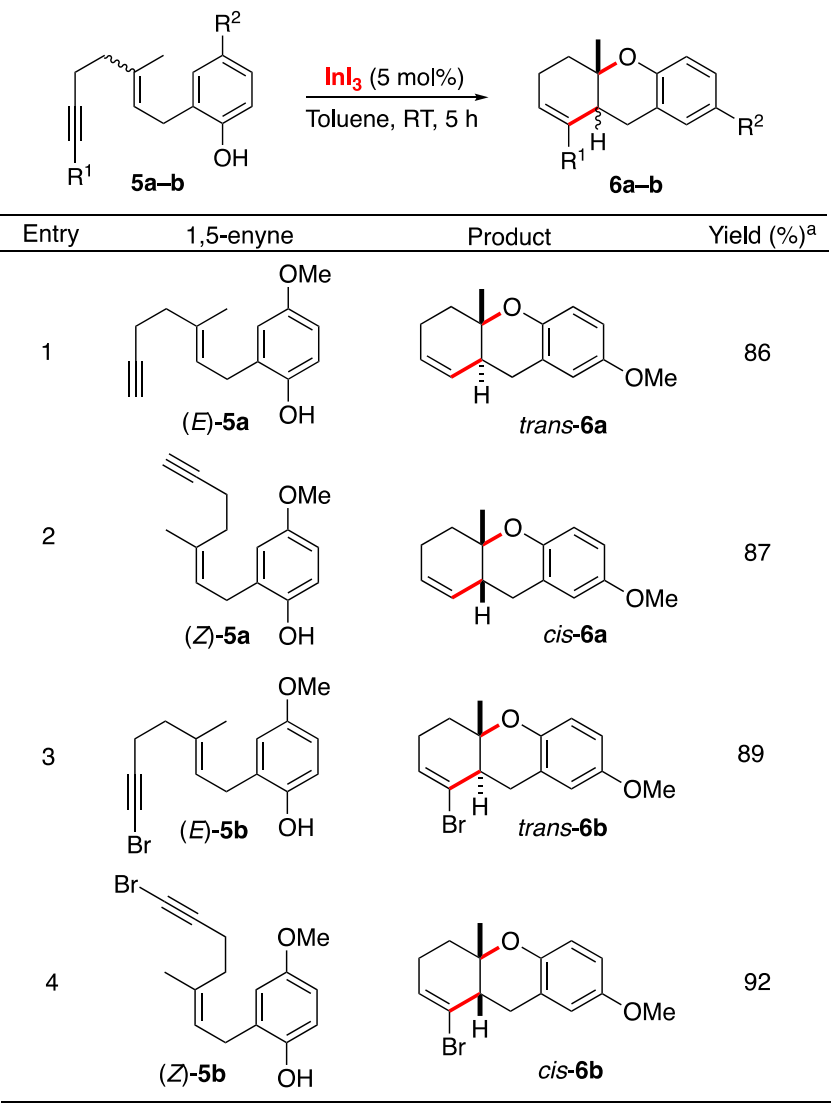

${ }^{a}$ Isolated yield.

Scheme 2. Sequential One-Pot In-Catalyzed 1,5-Enyne Cycloisomerization and Pd-Catalyzed Cross-Coupling Reaction with (E)-5b<smiles>CCCCCCCCCC#CCCC(C)=CCc1cc(OC)ccc1O</smiles>

$(E)-5 \mathbf{b}$

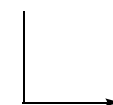

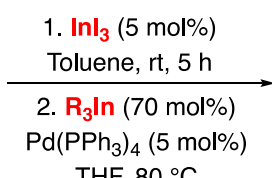
$\mathrm{THF}, 80^{\circ} \mathrm{C}$

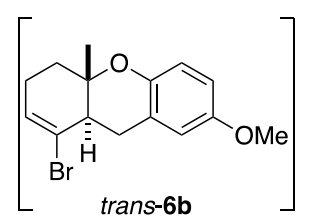

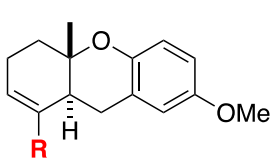

trans-6c, $\mathbf{R}=\mathbf{P h}, 76 \%$ trans-6d, $\mathrm{R}=\mathrm{Me}, 83 \%$

trans-6e, $\mathrm{R}=n \mathrm{Bu}, 81 \%$

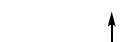

reaction using aryl 1,5-enynes and its chemical compatibility with Pd-catalyzed cross-coupling reactions.

Finally, the indium-catalyzed cycloisomerization reaction of 1,5-enynes with aryl nucleophiles at the $\mathrm{C}-5$ alkene unit $(7 \mathbf{a}-\mathbf{c})$ was also briefly studied (Table 5). These substrates should allow the synthesis of spiroheterocycles if the cycloisomerization proceeds with 6-endo regioselectivity according to the previously described cation-olefin mechanism. ${ }^{14 a}$ Interestingly, the treatment of 1,5-enyne $7 \mathbf{a}$ with $\operatorname{InI}_{3}(5 \mathrm{~mol} \%)$ in toluene at $60{ }^{\circ} \mathrm{C}$ afforded oxaspirane $\mathbf{8 a}$ as the only isolated product in an excellent yield of $84 \%$ (Table 5, entry 1). As expected, the cascade cycloisomerization reaction proceeded with 6-endo-dig/ endo-trig regioselectivity to afford the Markovnikov product

Table 5. Synthesis of Spiroheterocycles by Indium-Catalyzed Reaction with 1,5-Enynes $7 a-c^{c}$

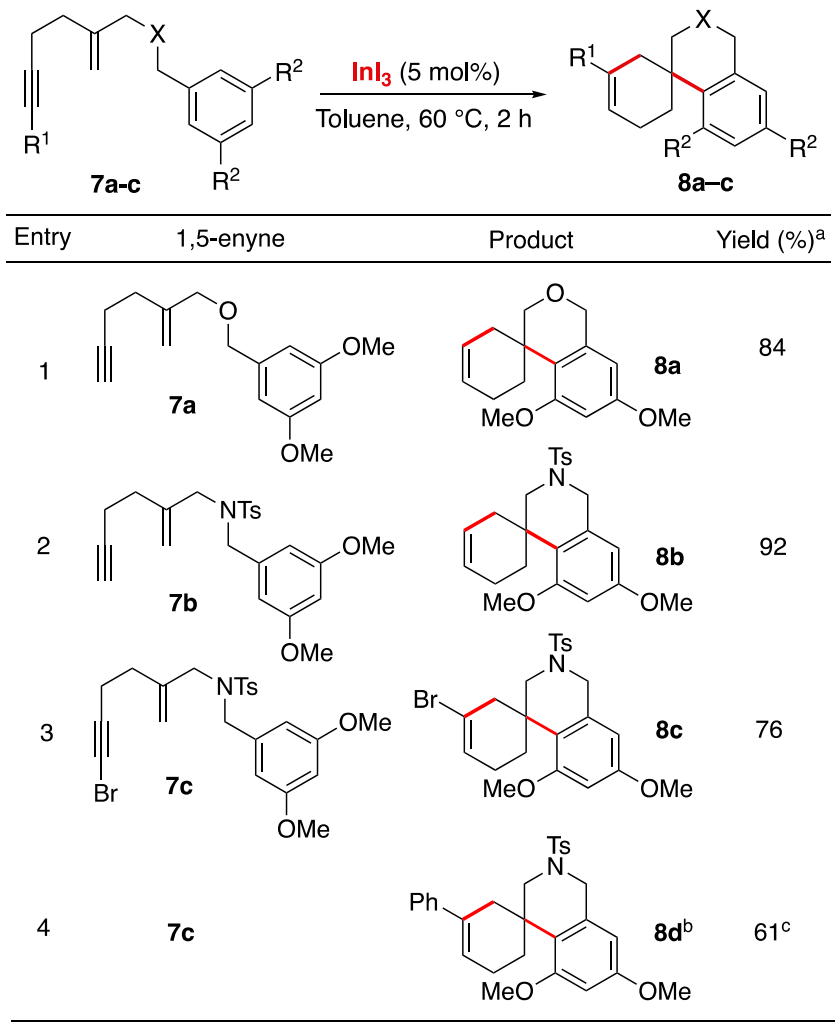

${ }^{a}$ Isolated yield. ${ }^{b}$ Obtained from $7 \mathrm{c}$ by sequential In-catalyzed cycloisomerization and Pd-catalyzed cross-coupling. ${ }^{c}$ Overall yield (two steps).

exclusively. Analogously, the reaction using 1,5-enynyl benzyl $N$ tosylamine $7 \mathbf{b}$ provided the azaspirane $8 \mathbf{b}$ in $92 \%$ yield (entry 2 ). The reaction with 1 -bromo-1,5-enyne $7 \mathrm{c}$ afforded the corresponding spirane $8 \mathrm{c}$ in $76 \%$ yield (entry 3 ). In addition, the one-pot sequential indium-catalyzed cycloisomerization of 7c followed by the cross-coupling reaction with $\mathrm{Ph}_{3} \mathrm{In}$ using $\mathrm{Pd}\left(\mathrm{PPh}_{3}\right)_{4}$ as the catalyst provided the phenyl-substituted azaspirane $8 \mathrm{~d}$ in $61 \%$ overall yield (two steps, entry 4 ).

Mechanistic Studies. According to the experimental results, we postulate that the course of the indium(III)-catalyzed double cascade cycloisomerization could be viewed as either a concerted process or a stepwise route depending on the arene nucleophilicity (Scheme 3). In a two-step mechanism, we postulate that the initial $\eta^{2}$ coordination of the indium(III) halide with the alkyne moiety (C) would trigger 1,5-enyne cyclization to form the intermediate $\mathbf{D} .^{2}$ This intermediate should not be a pure carbocation and could be seen as a resonance hybrid of two resonance structures, an indiumstabilized homoallylic carbocation (D) and a cyclopropylindium ylide. Once there, the second cyclization should proceed through a Friedel-Crafts type alkylation reaction, subsequent aromatization and protodemetallation should provide the corresponding tricyclic compound, regenerating the catalytic species (Scheme 3). The mechanistic pathway and the nature of the transition states and synthetic intermediates should also depend on the substituents at the alkene, alkyne, or arene units.

Our experimental data show that the In(III)-catalyzed double cycloisomerization reaction of aryl-substituted $(Z)$-1,5-enynes is stereoselective, yielding in all cases the cis adducts with 
Scheme 3. General Plausible Mechanism for the In(III)Catalyzed Cascade Cycloisomerization Reaction of 1,5Enynes $1 \mathrm{a}-\mathrm{d}$ and $3 \mathrm{a}-\mathrm{f}$

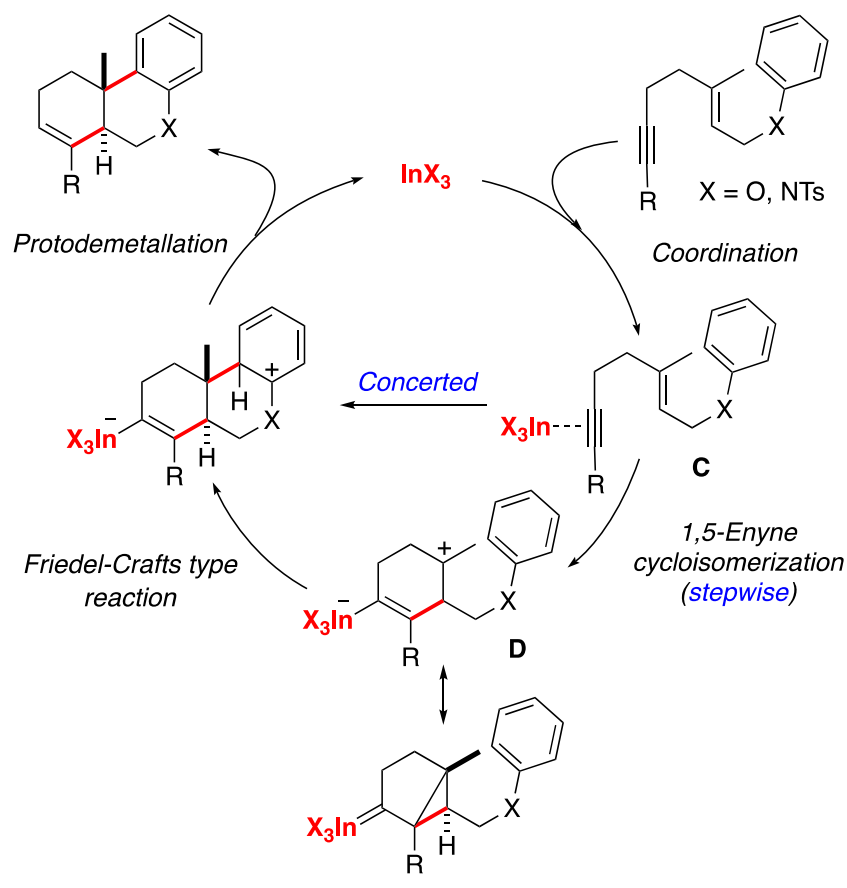

complete selectivity. For example, independently of the electronic nature of the aromatic ring, the final cis-products are obtained, cis-2a, cis-2c, and cis-2d from $(Z)-\mathbf{1 a},(Z)-\mathbf{1 c}$, and $(Z)$-1d, respectively (Table 2 , entries 5-7), as for the 1,5-enyne cycloisomerizations of Table 3 (entries 6-8) and Table 4. Accordingly, one would expect that using (E)-1,5-enynes, the tricyclic products would belong to the trans series. In fact, this is true for all of the dimethoxyphenyl, electron-rich arenes, 1,5enynes like $(E)-1 \mathrm{a}$ (Table 2 , entry 1 , cis/trans $=11: 89$ ), and others (Table 2, entries 1-3; Table 3, entries 1-4; Table 4). However, surprisingly, the unsubstituted phenyl 1,5-enynes $(E)$ 1d and (E)-3e break this rule, affording the opposite cis diastereoisomers of the final adduct cis-2d (Table 2, entry 4) and cis-4e (Table 3, entry 5). In other words, phenyl ether 1,5enynes $\mathbf{1 d}$ and $3 \mathrm{e}$ lead diastereoselectively to the cis final adducts, regardless of the $E$ or $Z$ configuration of the initial double bonds. To gain insights into the intriguing behavior of aryl 1,5-enynyl ethers $(E)-\mathbf{1 d}$ and $(E)$-3e, we set out to study the reaction theoretically. ${ }^{23}$

Computational studies $^{24}$ for $(Z)$ - and (E)-1,5-enynyl aryl ether 1a (Scheme 4) showed that the formation of the first cycle occurs via TS1-Z or TS1-E, two transition states originated by the nucleophilic 6-endo-dig alkene attack to the indium-activated electrophilic triple bond. The activation energy is very similar for the two compounds, 17.3 and $18.9 \mathrm{kcal} / \mathrm{mol}$, respectively. As expected, the aromatic ring does not participate in the formation of the first ring, which affords intermediates INT1 stereospecifically, INT 1-cis from $Z$, and INT 1-trans from $E$ starting materials. These intermediates are low in energy, $0.3-1.8 \mathrm{kcal} / \mathrm{mol}$, presenting a bicyclic structure [4.1.0] and a partial indium carbene character. The computational data shows that the first step (TS1) is rate limiting since the formation of the second cycle by an electrophilic aromatic substitution in TS2-type transition states proceeds with lower activation energies, 8.9 for TS2-cis and $12.6 \mathrm{kcal} / \mathrm{mol}$ for TS2-trans. As expected for this

Scheme 4. DFT-Calculated Mechanism of the Reaction of $(Z)-1 \mathrm{a}$ and (E)-1a for the Selective Formation of INT2-cis and -trans

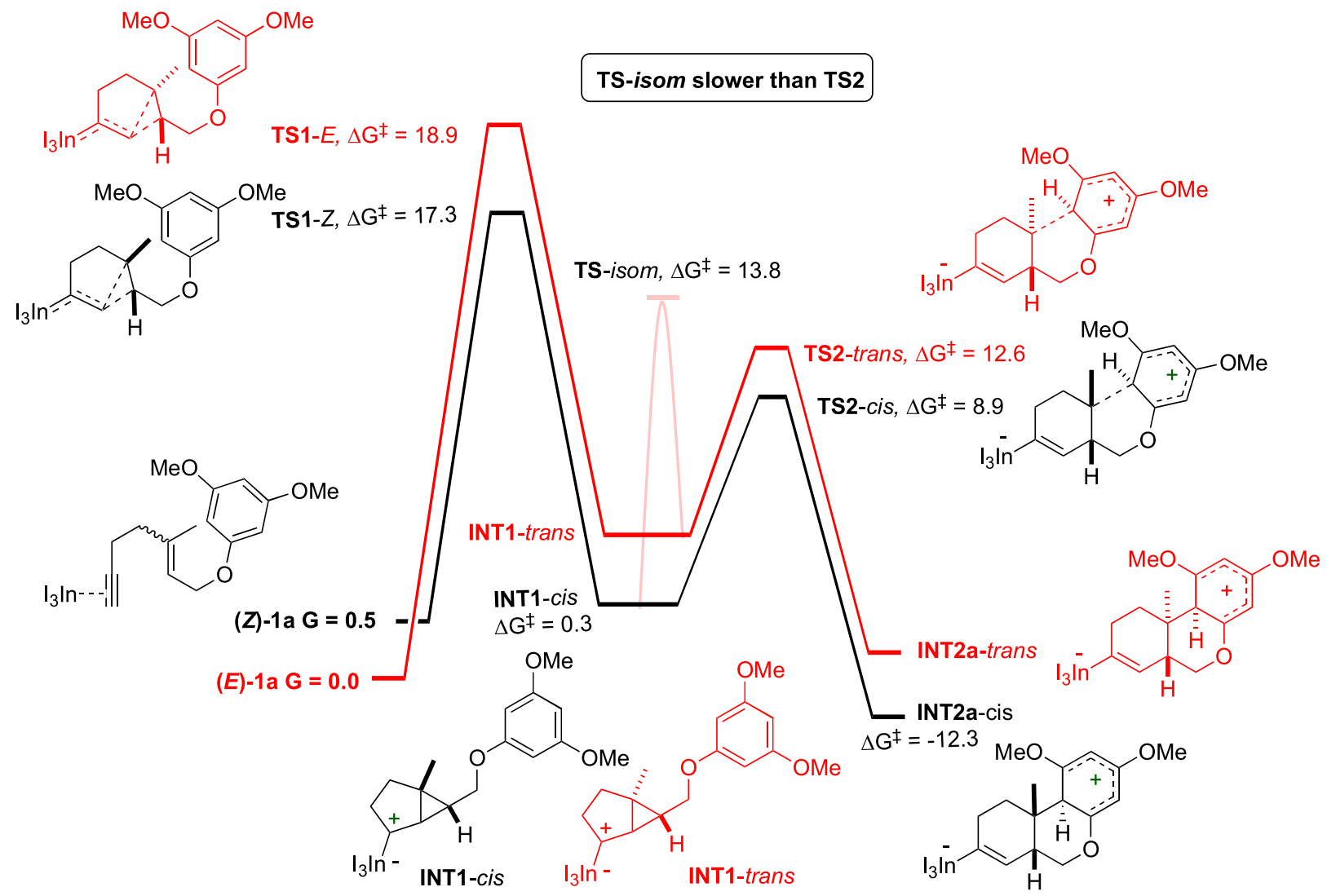


Scheme 5. DFT-Calculated Isomerization Process between the Intermediates INT1-cis and INT1-trans
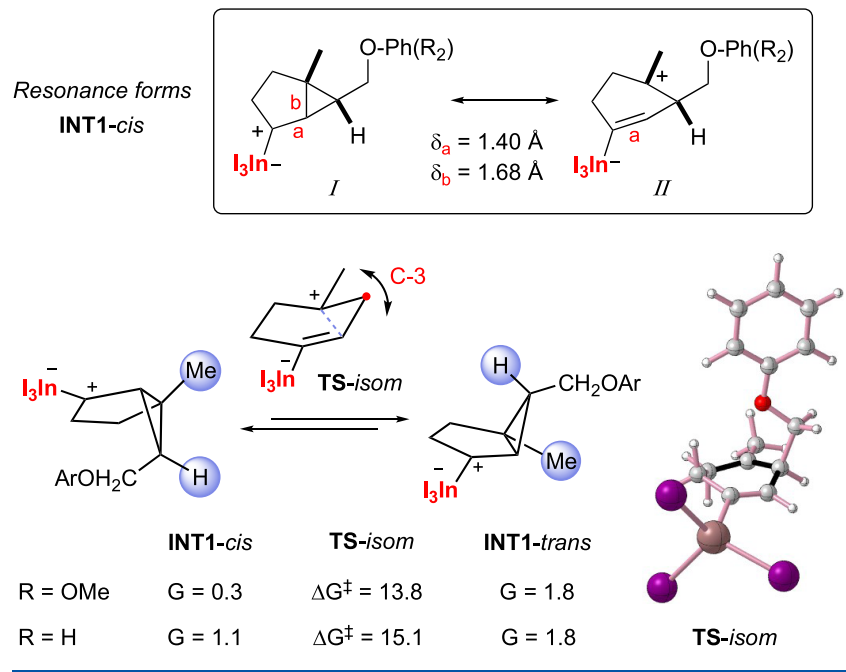

type of reaction $\left(S_{\mathrm{E}} A r\right)$, electron-rich arenes are positively affected by the stabilization of the incipient positive charge in the aryl ring by the electron-releasing methoxy groups. For the same reason, the arenium intermediates INT2a (cis and trans) are very stable in the presence of methoxy substituents $(-12.3$ and -7.6 $\mathrm{kcal} / \mathrm{mol}$ ). Although we did not compute them, the easy final deprotonation and hydrolysis (protodemetallation) of the C-In bond after INT2 $a$ intermediates would render exclusive adducts cis-2a (from Z-1a, black pathway in Scheme 4) and trans-2a (from E-1a, red line), in complete agreement with the experimental results.

Intermediate INT1 presents very interesting structures, as they can be described by two resonance forms, I and II (Scheme 5 , top). The former is a fused bicyclic skeleton with a polarized
C-In bond, whilst II shows the zwitterionic character, with the positive charge on the methylated tertiary carbon and an anionic alkenyl-indium motif. The NBO analysis of INT1(OMe) and INT1 $(\mathrm{H})$ affords Wiberg bond orders showing the mixed character of both structures, slightly more akin to structure $I$, since the internal $\mathrm{C}-\mathrm{C}$ bond $b$ is advanced but not completely formed $(\mathrm{BO}=0.67-0.81)$, and the $\mathrm{C}-\mathrm{C}$ bond $a$ presents slight but not complete double bond character $(\mathrm{BO}=1.33-1.43)$. The bonding distances also show mixed characteristics of both resonance forms, with computed values of $\delta_{\mathrm{a}}=1.40 \AA$ and $\delta_{\mathrm{b}}=$ $1.68 \AA$. Thus, resonance form II also has a significant participation in the actual structure of these intermediates. We rationalized that, given the weakness of bond $b$ and the partial carbocationic character at the C-3 position (Scheme 5, bottom), the bicyclic species INT1-cis and INT1-trans could potentially interconvert by an isomerization equilibrium. Indeed, a transition state was located (TS-isom) bearing an almost planar tertiary carbocation, where the adjacent carbon (labeled as C-3) is flipping between the upper and lower faces of the cyclohexene plane (Scheme 5). The activation energy of this process is quite low, ca. $13.5-15.1 \mathrm{kcal} / \mathrm{mol}$, making the isomerization plausible, at least in some circumstances. However, as mentioned before for, the 1a starting materials, the second step (TS2) is low enough in energy ( 8.9 and $12.6 \mathrm{kcal} / \mathrm{mol}$, Scheme 4) to outcompete the isomerization, providing a complete selectivity (experimental > 95:5) for the cis and trans final products.

The scenario is quite different for 1,5-enynes $(E)$ - and $(Z)$-1d without methoxy groups (Scheme 6). The initial cyclization through TS1 is also rate limiting, with values of 17.4 and 19.6 $\mathrm{kcal} / \mathrm{mol}$. After the first transition state, the structure and energies of INT 1 intermediates are very similar to the previous ones. However, due to the absence of stabilizing methoxy groups in the aromatic ring, the second cyclization (TS2) increases its energy significantly in $\mathrm{ca} .5-7 \mathrm{kcal} / \mathrm{mol}(12.8$ and $19.1 \mathrm{kcal} /$ mol, Scheme 6) above the values noted for 1a. This fact is

Scheme 6. DFT-Calculated Mechanism of the Reaction of (Z)-1d and (E)-1d under Curtin-Hammett Conditions

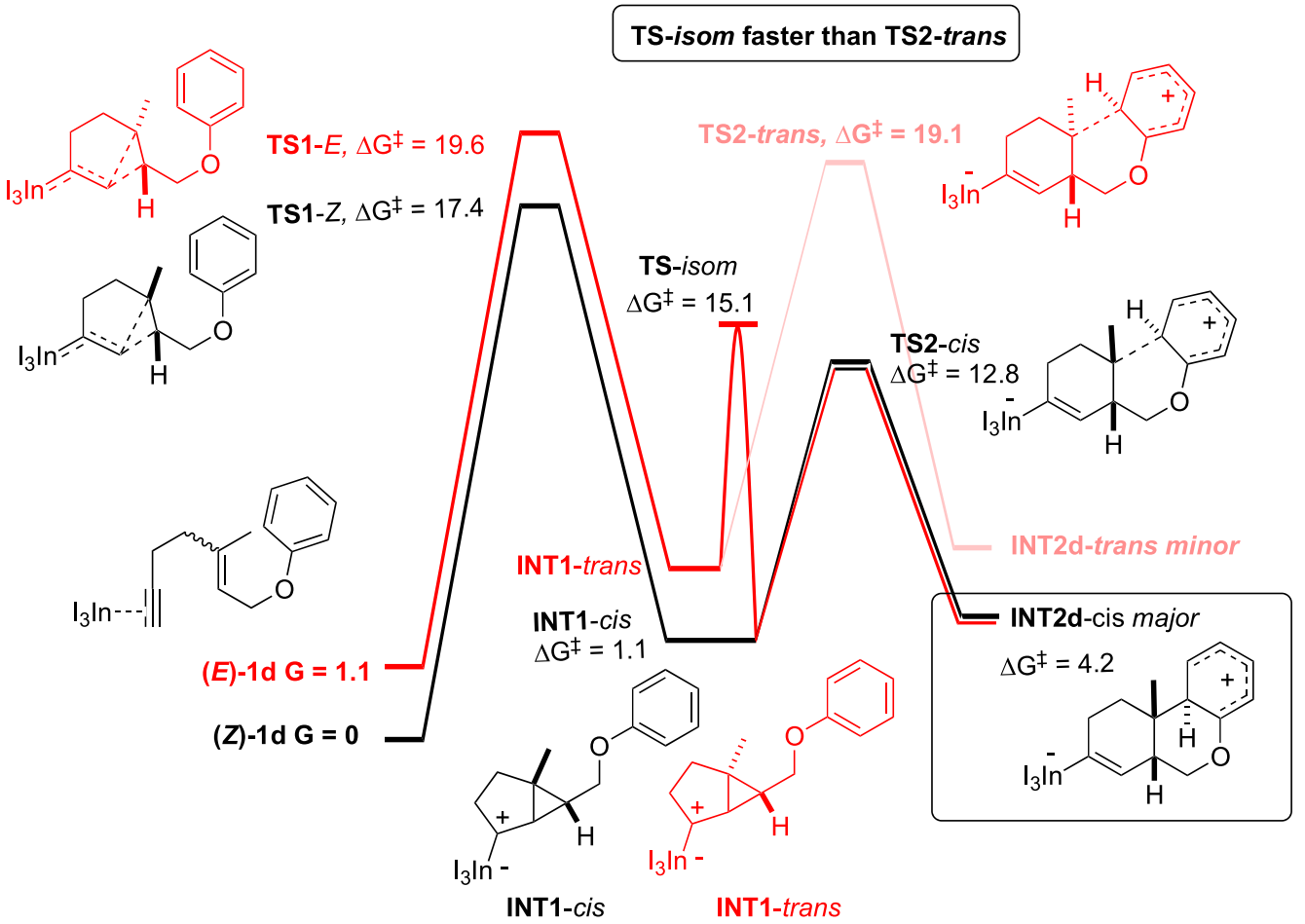


especially important in the case of the trans cyclization, which also shows larger ring strain, producing a sluggish cyclization $(19.1 \mathrm{kcal} / \mathrm{mol})$, which becomes slower than the isomerization $(15.1 \mathrm{kcal} / \mathrm{mol})$ between the two INT1 isomers. Therefore, intermediate INT1-trans prefers to isomerize to INT1-cis rather than cyclize, and the reaction follows the red line in Scheme 6 to cis isomer. Meanwhile, the double cyclization of the $Z$ isomer proceeds via the black line to lead stereospecifically to the cis isomer. These observations can explain how both starting materials converge in INT1-cis to give the same cis final isomer under Curtin-Hammett conditions.

\section{CONCLUSIONS}

Indium(III) iodide is an efficient catalyst to promote a double cycloisomerization reaction of 1,5-enynes with pendant aryl nucleophiles. The reaction can be performed under mild reaction conditions using $5 \mathrm{~mol} \%$ of catalyst and proceeds in cascade through alkyne electrophilic activation with complete 6endo regioselectivity via a biomimetic cascade cation-olefin process. In some cases, the double cycloisomerization is stereospecific with the retention of the alkene configuration. In addition, the synthetic transformation is highly versatile, allowing 1,5-enynes substituted at the alkyne and alkene units and phenyl groups and phenol derivatives as nucleophiles. Accordingly, a diverse group of polycyclic heterocycles such as benzo $[b]$ chromenes, phenanthridines, xanthenes, and spiroheterocyclic compounds was synthesized. Computational studies on aryl 1,5-enynyl ethers support a mechanism consisting of two consecutive cyclizations: the first one is a 6-endo-dig process catalyzed by a regioselective alkyne electrophilic activation and a second cyclization through a nonstereospecific $S_{\mathrm{E}} \mathrm{Ar}$ process.

\section{EXPERIMENTAL SECTION}

General Methods. All reactions were carried out in flame-dried glassware under argon using standard gastight syringes, cannulae, and septa. Toluene and THF were distilled from sodium/benzophenone. Dry $\mathrm{MeOH}, \mathrm{DCE}, \mathrm{Et}_{3} \mathrm{~N}$, and other commercially available reagents were used as received. Reaction temperatures refer to external bath temperatures. Butyllithium was titrated prior to use. Indium(III) iodide (99.998\%) and indium(III) bromide (99.999\%) were purchased from Aldrich and used as received under argon. The reactions were monitored by TLC using precoated silica gel plates (Alugram Xtra SIL G/UV254, $0.20 \mathrm{~mm}$ thick), UV light as the visualizing agent, and ethanolic phosphomolybdic acid as the developing agent. Flash column chromatography was performed with $230-400$ mesh silica gel. ${ }^{1} \mathrm{H}$ and ${ }^{13} \mathrm{C}$ NMR spectra were recorded in $\mathrm{CDCl}_{3}$ at $300 \mathrm{~K}$ using a Bruker Advance $300 \mathrm{MHz}, 400 \mathrm{MHz}$ or a Bruker Advance $500 \mathrm{MHz}$ spectrometer and calibrated to the solvent peak. Mass spectra were obtained with a MAT 95XP Magnetic Sector EI spectrometer or with a QSTAR Elite hybrid quadrupole time-of-flight (TOF) ESI mass spectrometer, both operating in the positive ionization mode. Gas chromatography (GC) was performed on a Trace 1300 autosampling GC with a TG-5SILMS capillary column and equipped with an ISQ QD mass spectrometer.

(E)-1,3-Dimethoxy-5-[(3-methyloct-2-en-6-yn-1-yl)oxy]benzene $[(E)-1 \mathrm{~b}] .{ }^{14 \mathrm{a}}$ To a cooled solution of enyne $(E)-1 \mathbf{a}^{14 \mathrm{c}}(202.8$ $\mathrm{mg}, 0.78 \mathrm{mmol})$ in dry THF $(10 \mathrm{~mL})$ at $0{ }^{\circ} \mathrm{C}, n-\mathrm{BuLi}(0.38 \mathrm{~mL}, 0.82$ $\mathrm{mmol}, 2.19 \mathrm{M}$ in hexanes) was added dropwise. After $30 \mathrm{~min}, \mathrm{MeI}(0,06$ $\mathrm{mL}, 0.94 \mathrm{mmol}$ ) was added, and the reaction mixture was stirred for $2 \mathrm{~h}$. The reaction was quenched with EtOH $(1 \mathrm{~mL})$, the solvent was evaporated, and the corresponding residue was purified by flash chromatography (2\% EtOAc/hexanes) to afford $(E)-1 \mathbf{b}(162.6 \mathrm{mg}$, $76 \%)$ as a colorless oil; ${ }^{1} \mathrm{H}$ NMR $\left(300 \mathrm{MHz}, \mathrm{CDCl}_{3}\right) \delta 6.11-6.09(\mathrm{~m}$, $3 \mathrm{H}), 5.54-5.50(\mathrm{~m}, 1 \mathrm{H}), 4.51(\mathrm{~d}, J=6.5 \mathrm{~Hz}, 2 \mathrm{H}), 3.77(\mathrm{~s}, 6 \mathrm{H}), 2.26$ (m, 4H), $1.77(\mathrm{~s}, 3 \mathrm{H}), 1.74(\mathrm{~s}, 3 \mathrm{H}) ;{ }^{13} \mathrm{C}\left\{{ }^{1} \mathrm{H}\right\} \mathrm{NMR}\left(75 \mathrm{MHz}, \mathrm{CDCl}_{3}\right)$ $\delta 161.6,160.9,139.9,120.5,93.7,93.1,78.6,76.2,65.0,55.5,39.0,17.7$,
16.7, 3.6; HRMS (ESI) $m / z$ : $[\mathrm{M}+\mathrm{Na}]^{+}$calcd for $\mathrm{C}_{17} \mathrm{H}_{22} \mathrm{O}_{3} \mathrm{Na}$ 297.1461; found 297.1458.

(E)-1-[(7-Bromo-3-methylhept-2-en-6-yn-1-yl)oxy]-3,5-dimethoxybenzene $[(E)-1 \mathrm{c}]$. To a room temperature solution of $(E)-3$ methylhept-2-en-6-yn-1-ol ${ }^{25}(105.7 \mathrm{mg}, 0.85 \mathrm{mmol})$ in acetone (5 $\mathrm{mL}), \mathrm{N}$-bromosuccinimide (NBS) $(166.7 \mathrm{mg}, 0.93 \mathrm{mmol})$ and $\mathrm{AgNO}_{3}$ $(15.8 \mathrm{mg}, 0.09 \mathrm{mmol})$ were added and the reaction mixture was stirred for $1 \mathrm{~h}$. The reaction mixture was diluted with $\mathrm{Et}_{2} \mathrm{O}(10 \mathrm{~mL})$, washed with $\mathrm{H}_{2} \mathrm{O}(10 \mathrm{~mL})$ and brine $(10 \mathrm{~mL})$, dried with anhydrous $\mathrm{MgSO}_{4}$, filtered, and concentrated in vacuo to afford (E)-7-bromo-3methylhept-2-en-6-yn-1-ol as an orange oil, which was used in the next step without further purification. The crude product was added to a solution of triphenylphosphine $(329.4 \mathrm{mg}, 1.25 \mathrm{mmol}$ ) and 3,5dimethoxyphenol $(193.2 \mathrm{mg}, 1.25 \mathrm{mmol})$ in THF $(10 \mathrm{~mL})$. To this solution at $0{ }^{\circ} \mathrm{C}$, diisopropyl azodicarboxylate (DIAD) $(0.25 \mathrm{~mL}, 1.25$ $\mathrm{mmol}$ ) was added dropwise and the reaction mixture was stirred for $5 \mathrm{~h}$ at $60{ }^{\circ} \mathrm{C}$. Then, the solvent was evaporated in vacuo and the corresponding residue was purified by flash chromatography (5\% EtOAc/hexanes) to afford (E)-1c (161.0 mg, $56 \%$ in two steps) as a yellow oil; ${ }^{1} \mathrm{H}$ NMR $\left(300 \mathrm{MHz}, \mathrm{CDCl}_{3}\right) \delta 6.10(\mathrm{~m}, 3 \mathrm{H}), 5.54-5.50(\mathrm{~m}$, $1 \mathrm{H}), 4.50(\mathrm{~d}, J=6.6 \mathrm{~Hz}, 2 \mathrm{H}), 3.76(\mathrm{~s}, 6 \mathrm{H}), 2.36-2.29(\mathrm{~m}, 4 \mathrm{H}), 1.74(\mathrm{~s}$, $3 \mathrm{H}) ;{ }^{13} \mathrm{C}\left\{{ }^{1} \mathrm{H}\right\}$ NMR $\left(75 \mathrm{MHz}, \mathrm{CDCl}_{3}\right) \delta 161.6,160.8,139.1,120.9$, 93.7, 93.1, 79.6, 64.8, 55.4, 38.6, 38.0, 18.6, 16.6; IR (neat) $\nu_{\max } 2929$, $2841,1594,1460,1204,1150,1062,819 \mathrm{~cm}^{-1}$; HRMS (ESI) $\mathrm{m} / z:[\mathrm{M}$ $+\mathrm{Na}]^{+}$calcd for $\mathrm{C}_{16} \mathrm{H}_{19} \mathrm{BrO}_{3} \mathrm{Na} 361.0409$; found 361.0416.

(E)-[(3-Methylhept-2-en-6-yn-1-yl)oxy]benzene [(E)-1d]. To a $0^{\circ} \mathrm{C}$ solution of $(E)$-3-methylhept-2-en-6-yn-1-ol ${ }^{25}$ (201.9 mg, 1.63 $\mathrm{mmol})$, triphenylphosphine $(640.0 \mathrm{mg}, 2.44 \mathrm{mmol})$ and phenol $(229.6$ $\mathrm{mg}, 2.44 \mathrm{mmol})$ in THF $(10 \mathrm{~mL})$, DIAD $(0.48 \mathrm{~mL}, 2.44 \mathrm{mmol})$ was added dropwise. The reaction mixture was stirred for $5 \mathrm{~h}$ at $60^{\circ} \mathrm{C}$ in an oil bath and the solvent was evaporated in vacuo. Then, the corresponding residue was purified by flash chromatography ( $5 \%$ EtOAc/hexanes) to afford (E)-1d (251.4 mg, 77\%) as a colorless oil; ${ }^{1} \mathrm{H}$ NMR $\left(300 \mathrm{MHz}, \mathrm{CDCl}_{3}\right) \delta 7.31-7.28(\mathrm{~m}, 2 \mathrm{H}), 6.94-6.93(\mathrm{~m}$, $3 \mathrm{H}), 5.58-5.53(\mathrm{~m}, 1 \mathrm{H}), 4.56(\mathrm{~d}, J=6.5 \mathrm{~Hz}, 2 \mathrm{H}), 2.35-2.31(\mathrm{~m}, 4 \mathrm{H})$, $1.95(\mathrm{t}, J=2.3 \mathrm{~Hz}, 1 \mathrm{H}), 1.75(\mathrm{~s}, 3 \mathrm{H}) ;{ }^{13} \mathrm{C}\left\{{ }^{1} \mathrm{H}\right\} \operatorname{NMR}\left(75 \mathrm{MHz}, \mathrm{CDCl}_{3}\right)$ $\delta 158.9,139.1,129.5,121.1,120.8,114.8,83.9,68.9,64.7,38.3,17.3$, 16.6; HRMS (EI) $m / z$ : $[\mathrm{M}]^{+}$calcd for $\mathrm{C}_{14} \mathrm{H}_{16} \mathrm{O}$ 200.1201; found 200.1196

(Z)-1,3-Dimethoxy-5-[(3-methylhept-2-en-6-yn-1-yl)oxy]benzene $[(Z)-1 \mathrm{a}]$. DIAD $(0.51 \mathrm{~mL}, 2.57 \mathrm{mmol})$ was added dropwise at $0{ }^{\circ} \mathrm{C}$ to a solution of $(Z)$-3-methylhept-2-en-6-yn-1-ol ${ }^{26}(212.6 \mathrm{mg}$, $1.71 \mathrm{mmol})$, triphenylphosphine $(674.1 \mathrm{mg}, 2.57 \mathrm{mmol})$, and $3,5-$ dimethoxyphenol $(396.2 \mathrm{mg}, 2.57 \mathrm{mmol})$ in THF $(10 \mathrm{~mL})$. The reaction mixture was stirred for $3 \mathrm{~h}$ at $60{ }^{\circ} \mathrm{C}$ in an oil bath and the solvent was evaporated in vacuo. Then, the corresponding residue was purified by flash chromatography (5\% EtOAc/hexanes) to afford $(Z)$ 1a $(227.3 \mathrm{mg}, 51 \%)$ as a colorless oil; ${ }^{1} \mathrm{H}$ NMR $\left(300 \mathrm{MHz}, \mathrm{CDCl}_{3}\right) \delta$ $6.11-6.09(\mathrm{~m}, 3 \mathrm{H}), 5.60(\mathrm{td}, J=6.8,1.6 \mathrm{~Hz}, 1 \mathrm{H}), 4.51(\mathrm{~d}, J=6.8 \mathrm{~Hz}$, $2 \mathrm{H}), 3.76(\mathrm{~s}, 6 \mathrm{H}), 2.36-2.34(\mathrm{~m}, 4 \mathrm{H}), 1.97(\mathrm{t}, J=2.4 \mathrm{~Hz}, 1 \mathrm{H}), 1.81(\mathrm{~s}$, $3 \mathrm{H}) ;{ }^{13} \mathrm{C}\left\{{ }^{1} \mathrm{H}\right\}$ NMR $\left(75 \mathrm{MHz}, \mathrm{CDCl}_{3}\right) \delta 161.6,160.7,139.7,122.0$, 93.6, 93.0, 83.7, 69.0, 64.5, 55.4, 31.2, 23.3, 17.5; IR (neat) $\nu_{\max } 3289$, 2935, 2840, 1593, 1474, 1204, 1147, 1060, $818 \mathrm{~cm}^{-1}$; HRMS (ESI) $\mathrm{m} /$ $z:[\mathrm{M}+\mathrm{Na}]^{+}$calcd for $\mathrm{C}_{16} \mathrm{H}_{20} \mathrm{O}_{3} \mathrm{Na} 283.1304$; found 283.1313.

(Z)-1-[(7-Bromo-3-methylhept-2-en-6-yn-1-yl)oxy]-3,5-dimethoxybenzene $[(Z)-1 \mathrm{c}]$. To a room temperature solution of $(Z)$ 3-methylhept-2-en-6-yn-1-ol ${ }^{26}(115.7 \mathrm{mg}, 0.93 \mathrm{mmol})$ in acetone $(5$ $\mathrm{mL})$, NBS (182.4 mg, $1.02 \mathrm{mmol}$ ) and $\mathrm{AgNO}_{3}(17.3 \mathrm{mg}, 0.10 \mathrm{mmol})$ were added and the reaction mixture was stirred for $1 \mathrm{~h}$. The reaction mixture was diluted with $\mathrm{Et}_{2} \mathrm{O}(10 \mathrm{~mL})$ and washed with $\mathrm{H}_{2} \mathrm{O}(10 \mathrm{~mL})$ and brine $(10 \mathrm{~mL})$, dried with $\mathrm{MgSO}_{4}$ (anhydrous), filtered, and concentrated in vacuo to afford (Z)-7-bromo-3-methylhept-2-en-6-yn1 -ol as an orange oil, which was used in the next step without further purification. The crude product was added to a solution of triphenylphosphine $(354.0 \mathrm{mg}, 1.35 \mathrm{mmol})$ and 3,5-dimethoxyphenol $(208.9 \mathrm{mg}, 1.35 \mathrm{mmol})$ in THF $(10 \mathrm{~mL}), \mathrm{DIAD}(0.26 \mathrm{~mL}, 1.35 \mathrm{mmol})$ at $0{ }^{\circ} \mathrm{C}$ was added dropwise, and the reaction mixture was heated at 60 ${ }^{\circ} \mathrm{C}$ for $5 \mathrm{~h}$. Then, the solvent was evaporated in vacuo and the corresponding residue was purified by flash chromatography ( $5 \%$ EtOAc/hexanes) to afford ( $Z$ )-1c (149.9 mg, $47 \%$ in two steps) as a 
yellow oil; ${ }^{1} \mathrm{H}$ NMR $\left(300 \mathrm{MHz}, \mathrm{CDCl}_{3}\right) \delta 6.11-6.09(\mathrm{~m}, 3 \mathrm{H}), 5.61(\mathrm{~m}$, $1 \mathrm{H}), 4.49(\mathrm{~d}, J=6.7 \mathrm{~Hz}, 2 \mathrm{H}), 3.77(\mathrm{~s}, 6 \mathrm{H}), 2.34(\mathrm{~m}, 4 \mathrm{H}), 1.80(\mathrm{~s}, 3 \mathrm{H})$; ${ }^{13} \mathrm{C}\left\{{ }^{1} \mathrm{H}\right\}$ NMR $\left(75 \mathrm{MHz}, \mathrm{CDCl}_{3}\right) \delta 161.5,160.7,139.5,122.0,93.6$, 93.1, 79.5, 64.4, 55.4, 38.8, 31.0, 23.3, 18.8; IR (neat) $\nu_{\max } 2927,2840$, $1593,1474,1204,1148,1061,818 \mathrm{~cm}^{-1}$; HRMS (ESI) $\mathrm{m} / z:[\mathrm{M}+\mathrm{Na}]^{+}$ calcd for $\mathrm{C}_{16} \mathrm{H}_{19} \mathrm{BrO}_{3} \mathrm{Na} 361.0409$; found 361.0403 .

(Z)-[(3-Methylhept-2-en-6-yn-1-yl)oxy]benzene [(Z)-1d]. To a cooled solution of (Z)-3-methylhept-2-en-6-yn-1-ol ${ }^{26}$ (215.8 mg, $1.74 \mathrm{mmol})$, triphenylphosphine $(684.6 \mathrm{mg}, 2.61 \mathrm{mmol})$ and phenol $(245.6 \mathrm{mg}, 2.61 \mathrm{mmol})$ in THF $(10 \mathrm{~mL})$ at $0{ }^{\circ} \mathrm{C}$, DIAD $(0.52 \mathrm{~mL}, 2.61$ $\mathrm{mmol}$ ) was added dropwise and the reaction mixture was stirred for $5 \mathrm{~h}$ at $60{ }^{\circ} \mathrm{C}$ in an oil bath. The solvent was evaporated in vacuo and the corresponding residue was purified by flash chromatography $(5 \%$ EtOAc/hexanes) to afford $(Z)-1 d(236.7 \mathrm{mg}, 68 \%)$ as a colorless oil; ${ }^{1} \mathrm{H}$ NMR $\left(300 \mathrm{MHz}, \mathrm{CDCl}_{3}\right) \delta 7.31-7.25(\mathrm{~m}, 2 \mathrm{H}), 6.95-6.91(\mathrm{~m}$, $3 \mathrm{H}), 5.62-5.60(\mathrm{~m}, 1 \mathrm{H}), 4.55(\mathrm{~d}, J=6.8,2 \mathrm{H}), 2.38-2.33(\mathrm{~m}, 4 \mathrm{H})$, $1.98-1.96(\mathrm{~m}, 1 \mathrm{H}), 1.82(\mathrm{~s}, 3 \mathrm{H}) ;{ }^{13} \mathrm{C}\left\{{ }^{1} \mathrm{H}\right\} \operatorname{NMR}\left(75 \mathrm{MHz} \mathrm{CDCl}_{3}\right) \delta$ 158.8, 139.5, 129.5, 122.2, 120.8, 114.8, 83.8, 69.0, 64.3, 31.3, 23.3, 17.5; IR (neat) $\nu_{\max } 3292,2917,2868,1598,1494,1235,1172,1006$, $752 \mathrm{~cm}^{-1}$; HRMS (EI) $\mathrm{m} / z$ : $[\mathrm{M}]^{+}$calcd for $\mathrm{C}_{14} \mathrm{H}_{16} \mathrm{O} 200.1201$; found 200.1197.

(E)-N-(3,5-Dimethoxyphenyl)-4-methyl- $N$-(3-methyloct-2en-6-yn-1-yl)benzenesulfonamide $[(E)-3 b]$. To a $0{ }^{\circ} \mathrm{C}$ solution of 1,5 -enyne $(E)-3 a^{14 c}(205.6 \mathrm{mg}, 0.50 \mathrm{mmol})$ in dry THF $(10 \mathrm{~mL}), n$ BuLi $(0.21 \mathrm{~mL}, 0.52 \mathrm{mmol}, 2.5 \mathrm{M}$ in hexanes) was added dropwise. After $30 \mathrm{~min}$, MeI $(0,04 \mathrm{~mL}, 0.60 \mathrm{mmol})$ was added and the reaction mixture was left stirring for $2 \mathrm{~h}$. The reaction was quenched with EtOH $(3 \mathrm{~mL})$, the solvent was evaporated, and the corresponding residue was purified by flash chromatography ( $10 \% \mathrm{EtOAc} /$ hexanes) to afford $(E)$ $3 \mathbf{b}(108.4 \mathrm{mg}, 51 \%)$ as a white solid; ${ }^{1} \mathrm{H}$ NMR $\left(300 \mathrm{MHz}, \mathrm{CDCl}_{3}\right) \delta$ $7.56(\mathrm{~d}, J=8.4 \mathrm{~Hz}, 2 \mathrm{H}), 7.28-7.25(\mathrm{~m}, 2 \mathrm{H}), 6.36(\mathrm{~d}, J=2.1 \mathrm{~Hz}, 1 \mathrm{H})$, $6.20(\mathrm{~d}, J=2.1 \mathrm{~Hz}, 2 \mathrm{H}), 5.15(\mathrm{t}, J=7.0 \mathrm{~Hz}, 1 \mathrm{H}), 4.13(\mathrm{~d}, J=6.9 \mathrm{~Hz}$, $2 \mathrm{H}), 3.71(\mathrm{~s}, 6 \mathrm{H}), 2.42(\mathrm{~s}, 3 \mathrm{H}), 2.07(\mathrm{~m}, 4 \mathrm{H}), 1.72(\mathrm{~s}, 3 \mathrm{H}), 1.52(\mathrm{~s}$, $3 \mathrm{H}) ;{ }^{13} \mathrm{C}\left\{{ }^{1} \mathrm{H}\right\} \mathrm{NMR}\left(75 \mathrm{MHz}, \mathrm{CDCl}_{3}\right) \delta 160.5,143.4,141.3,139.1$, $135.8,129.4,127.9,119.7,107.0,100.1,78.5,76.0,55.5,48.7,38.8$, 21.6, 17.7, 16.2, 3.5; HRMS (ESI) $m / z:[\mathrm{M}+\mathrm{H}]^{+}$calcd for $\mathrm{C}_{24} \mathrm{H}_{30} \mathrm{NO}_{4} \mathrm{~S}$ 428.1890; found 428.1893 .

(E)-N-(3,5-Dimethoxyphenyl)-4-methyl- $N$-(3-methyl-7-phenylhept-2-en-6-yn-1-yl)benzenesulfonamide $[(E)-3 c]$. To a solution of 1,5 -enyne $(E)-3 \mathrm{a}^{14 \mathrm{c}}(163.0 \mathrm{mg}, 0.39 \mathrm{mmol})$ in $\mathrm{Et}_{3} \mathrm{~N}(4$ $\mathrm{mL}), \mathrm{CuI}(3.75 \mathrm{mg}, 0.02 \mathrm{mmol}), \mathrm{Pd}\left(\mathrm{PPh}_{3}\right)_{2} \mathrm{Cl}_{2}(13.83 \mathrm{mg}, 0.02 \mathrm{mmol})$, and iodobenzene $(103.4 \mathrm{mg}, 0.51 \mathrm{mmol})$ were added and the reaction mixture was stirred overnight at room temperature. Then, the reaction was quenched with $\mathrm{H}_{2} \mathrm{O}(15 \mathrm{~mL})$ and the aqueous phase was extracted with $\mathrm{Et}_{2} \mathrm{O}(3 \times 15 \mathrm{~mL})$. The combined organic phase was washed with brine $(50 \mathrm{~mL})$, dried with $\mathrm{MgSO}_{4}$ (anhyd.), filtered, and concentrated in vacuo to afford (E)-3c (107.9 g, 57\%) as an amorphous white solid after purification by column chromatography (10\% EtOAc/hexanes); ${ }^{1} \mathrm{H}$ NMR $\left(300 \mathrm{MHz}, \mathrm{CDCl}_{3}\right) \delta 7.56(\mathrm{~d}, J=8.2 \mathrm{~Hz}, 2 \mathrm{H}), 7.34(\mathrm{dd}, J=$ 6.7, $3.1 \mathrm{~Hz}, 2 \mathrm{H}), 7.27-7.24(\mathrm{~m}, 5 \mathrm{H}), 6.35(\mathrm{t}, J=2.3 \mathrm{~Hz}, 1 \mathrm{H}), 6.20(\mathrm{~d}, J$ $=2.3 \mathrm{~Hz}, 2 \mathrm{H}), 5.22(\mathrm{t}, J=6.7 \mathrm{~Hz}, 1 \mathrm{H}), 4.15(\mathrm{~d}, J=6.8 \mathrm{~Hz}, 2 \mathrm{H}), 3.68(\mathrm{~s}$, $6 \mathrm{H}), 2.42(\mathrm{~s}, 3 \mathrm{H}), 2.36(\mathrm{t}, J=7.5 \mathrm{~Hz}, 2 \mathrm{H}), 2.20(\mathrm{t}, J=7.5 \mathrm{~Hz}, 2 \mathrm{H}), 1.58$ $(\mathrm{s}, J=1.3 \mathrm{~Hz}, 3 \mathrm{H}) ;{ }^{13} \mathrm{C}\left\{{ }^{1} \mathrm{H}\right\} \mathrm{NMR}\left(75 \mathrm{MHz}, \mathrm{CDCl}_{3}\right) \delta 160.6,143.5$, $141.3,138.9,135.8,131.6,129.5,128.3,127.9,127.7,123.9,120.1$, $107.1,100.2,89.6,82.2,81.1,55.5,48.7,38.5,21.7,18.6,16.4$; IR (neat) $\nu_{\max } 2925,2841,1596,1458,1346,1205,1154,1066,663 \mathrm{~cm}^{-1}$; HRMS (ESI) $\mathrm{m} / z$ : $[\mathrm{M}+\mathrm{Na}]^{+}$calcd for $\mathrm{C}_{29} \mathrm{H}_{31} \mathrm{NO}_{4} \mathrm{SNa}$ : 512.1866; found 512.1853.

(E)-N-(7-Bromo-3-methylhept-2-en-6-yn-1-yl)-N-(3,5-dimethoxyphenyl)-4-methylbenzenesulfonamide $[(E)-3 \mathrm{~d}] .{ }^{14 c}$ NBS $(125.0 \mathrm{mg}, 0.70 \mathrm{mmol})$ and $\mathrm{AgNO}_{3}(12.0 \mathrm{mg}, 0.07 \mathrm{mmol})$ were added to a solution of the enyne $(E)-3 \mathrm{a}(266.3 \mathrm{mg}, 0.64 \mathrm{mmol})$ in acetone $(6 \mathrm{~mL})$, and the reaction mixture was stirred for $1 \mathrm{~h}$ at room temperature. The reaction mixture was diluted with $\mathrm{Et}_{2} \mathrm{O}(10 \mathrm{~mL})$, the organic phase was washed with $\mathrm{H}_{2} \mathrm{O}(10 \mathrm{~mL})$ and brine $(10 \mathrm{~mL})$, dried with $\mathrm{MgSO}_{4}$ (anhyd.), filtered, and concentrated in vacuo to afford, after purification by column chromatography (15\% EtOAc/hexanes), (E)3d (198.0 mg, 74\%) as a yellow oil; ${ }^{1} \mathrm{H}$ NMR $\left(300 \mathrm{MHz}, \mathrm{CDCl}_{3}\right) \delta 7.56$ $(\mathrm{d}, J=8.0 \mathrm{~Hz}, 2 \mathrm{H}), 7.28(\mathrm{~m}, 2 \mathrm{H}), 6.37(\mathrm{~m}, J=2.3 \mathrm{~Hz}, 1 \mathrm{H}), 6.20(\mathrm{~d}, J=$ $2.3 \mathrm{~Hz}, 2 \mathrm{H}), 5.16(\mathrm{t}, J=6.7 \mathrm{~Hz}, 1 \mathrm{H}), 4.13(\mathrm{~d}, J=6.9 \mathrm{~Hz}, 2 \mathrm{H}), 3.71(\mathrm{~s}$,
$6 \mathrm{H}), 2.42(\mathrm{~s}, 3 \mathrm{H}), 2.16-2.10(\mathrm{~m}, 4 \mathrm{H}), 1.55(\mathrm{~s}, 3 \mathrm{H}) ;{ }^{13} \mathrm{C}\left\{{ }^{1} \mathrm{H}\right\} \mathrm{NMR}$ $\left(75 \mathrm{MHz}, \mathrm{CDCl}_{3}\right) \delta 160.6,143.5,141.3,138.5,135.9,129.5,127.9$, 120.2, 107.1, 100.2, 79.6, 55.5, 48.6, 38.4, 38.0, 21.7, 18.7, 16.3; HRMS (ESI) $m / z:[\mathrm{M}+\mathrm{Na}]^{+}$calcd for $\mathrm{C}_{23} \mathrm{H}_{26} \mathrm{BrNO}_{4} \mathrm{SNa} 514.0658$; found: 514.0645 .

(E)-4-Methyl-N-(3-methylhept-2-en-6-yn-1-yl)-N-phenylbenzenesulfonamide $[(E)-3 e]$. DIAD $(0.36 \mathrm{~mL}, 1.81 \mathrm{mmol})$ was added dropwise at $0{ }^{\circ} \mathrm{C}$ to a solution of $(E)$-3-methylhept-2-en-6-yn-1$\mathrm{ol}^{25}$ (150.0 mg, $1.21 \mathrm{mmol}$ ), triphenylphosphine (474.7 mg, 1.81 $\mathrm{mmol})$, and $p$-toluenesulfonanilide $(447.6 \mathrm{mg}, 1.81 \mathrm{mmol})$ in THF (10 $\mathrm{mL}$ ). The reaction mixture was stirred for $5 \mathrm{~h}$ at $60^{\circ} \mathrm{C}$ in an oil bath and the solvent was evaporated in vacuo. The corresponding residue was purified by flash chromatography (20\% EtOAc/hexanes) to afford $(E)$ 3 e $(303.7 \mathrm{mg}, 71 \%)$ as a colorless oil; ${ }^{1} \mathrm{H}$ NMR $\left(300 \mathrm{MHz}, \mathrm{CDCl}_{3}\right) \delta$ $7.51(\mathrm{~d}, J=8.3 \mathrm{~Hz}, 2 \mathrm{H}), 7.27-7.24(\mathrm{~m}, 5 \mathrm{H}), 7.06-7.04(\mathrm{~m}, 2 \mathrm{H}), 5.18$ $(\mathrm{ddt}, J=8.2,6.9,1.3 \mathrm{~Hz}, 1 \mathrm{H}), 4.19(\mathrm{~d}, J=7.0 \mathrm{~Hz}, 2 \mathrm{H}), 2.42(\mathrm{~s}, 3 \mathrm{H})$, $2.10(\mathrm{~m}, 4 \mathrm{H}), 1.84(\mathrm{~m}, 1 \mathrm{H}), 1.49(\mathrm{~s}, 3 \mathrm{H}) ;{ }^{13} \mathrm{C}\left\{{ }^{1} \mathrm{H}\right\}$ NMR $(75 \mathrm{MHz}$, $\left.\mathrm{CDCl}_{3}\right) \delta 143.4,139.4,138.7,135.8,129.5,129.0,128.9,127.9,127.8$, $120.1,83.7,68.8,48.5,38.1,21.7,17.3,16.1$; IR (neat) $\nu_{\max } 3295,2972$, 2922, 1598, 1494, 1345, 1156, 1091, $654 \mathrm{~cm}^{-1}$; HRMS (ESI) $\mathrm{m} / \mathrm{z}$ : [M $+\mathrm{Na}]^{+}$calcd for $\mathrm{C}_{21} \mathrm{H}_{23} \mathrm{NO}_{2} \mathrm{SNa}$ : 376.1341 ; found: 376.1338 .

(Z)-N-(3,5-Dimethoxyphenyl)-4-methyl- $N$-(3-methylhept-2en-6-yn-1-yl)benzenesulfonamide [(Z)-3a]. DIAD $(0.34 \mathrm{~mL}, 1.74$ mmol) was added dropwise at $0{ }^{\circ} \mathrm{C}$ to a solution of $(Z)$-3-methylhept2-en-6-yn-1-ol ${ }^{26}(144.2 \mathrm{mg}, 1.16 \mathrm{mmol})$, triphenylphosphine (456.4 $\mathrm{mg}, 1.74 \mathrm{mmol})$, and $\mathrm{N}$-(3,5-dimethoxybenzyl)-4-methylbenzenesulfonamide $^{27}(534.4 \mathrm{mg}, 1.74 \mathrm{mmol})$ in THF $(10 \mathrm{~mL})$. The reaction mixture was stirred for $5 \mathrm{~h}$ at $60^{\circ} \mathrm{C}$ in an oil bath and the solvent was evaporated in vacuo. The corresponding crude reaction product was purified by flash chromatography (15\% EtOAc/hexanes) to afford $(Z)$ 3a (359.8 mg, 75\%) as a white solid; mp $100-102{ }^{\circ} \mathrm{C}$; ${ }^{1} \mathrm{H}$ NMR (300 $\left.\mathrm{MHz}, \mathrm{CDCl}_{3}\right) \delta 7.55(\mathrm{~d}, J=8.3 \mathrm{~Hz}, 2 \mathrm{H}), 7.28-7.25(\mathrm{~m}, 2 \mathrm{H}), 6.37(\mathrm{t}, J$ $=2.3 \mathrm{~Hz}, 1 \mathrm{H}), 6.20(\mathrm{~d}, J=2.3 \mathrm{~Hz}, 2 \mathrm{H}), 5.24-5.20(\mathrm{~m}, 1 \mathrm{H}), 4.15(\mathrm{dd}, J$ $=7.0,1.2 \mathrm{~Hz}, 2 \mathrm{H}), 3.71(\mathrm{~s}, 6 \mathrm{H}), 2.43(\mathrm{~s}, 3 \mathrm{H}), 2.14-2.09(\mathrm{~m}, 4 \mathrm{H}), 1.90$ (m, 1H), $1.63(\mathrm{~s}, 3 \mathrm{H}) ;{ }^{13} \mathrm{C}\left\{{ }^{1} \mathrm{H}\right\} \mathrm{NMR}\left(75 \mathrm{MHz}^{\mathrm{CDCl}}{ }_{3}\right) \delta 160.6$, 143.4, 141.2, 138.2, 135.7, 129.4, 127.8, 121.4, 107.1, 100.1, 83.8, 68.8, 55.4, 48.5, 30.7, 23.0, 21.6, 17.1; IR (neat) $\nu_{\max } 3294,2927,2840,1594$, $1459,1348,1154,1065,663 \mathrm{~cm}^{-1}$; HRMS (ESI) $\mathrm{m} / z:[\mathrm{M}+\mathrm{Na}]^{+}$calcd for $\mathrm{C}_{23} \mathrm{H}_{27} \mathrm{NO}_{4} \mathrm{SNa} 436.1553$; found 436.1555 .

(Z)-N-(7-Bromo-3-methylhept-2-en-6-yn-1-yl)-N-(3,5-dimethoxyphenyl)-4-methylbenzenesulfonamide $[(Z)-3 d]$. NBS $(75.0 \mathrm{mg}, 0.42 \mathrm{mmol})$ and $\mathrm{AgNO}_{3}(7.1 \mathrm{mg}, 0.04 \mathrm{mmol})$ were added to a solution of 1,5 -enyne $(Z)-3 \mathrm{a}(158.3 \mathrm{mg}, 0.38 \mathrm{mmol})$ in acetone (5 $\mathrm{mL}$ ), and the reaction mixture was stirred for $1 \mathrm{~h}$ at room temperature. The reaction mixture was diluted with $\mathrm{Et}_{2} \mathrm{O}(10 \mathrm{~mL})$, the organic phase was washed with $\mathrm{H}_{2} \mathrm{O}(10 \mathrm{~mL})$ and brine $(10 \mathrm{~mL})$, dried with $\mathrm{MgSO}_{4}$ (anhyd.), filtered, and concentrated in vacuo. After purification by column chromatography (15\% EtOAc/hexanes), $(Z)-3 \mathrm{~d}$ was obtained $(128.9 \mathrm{mg}, 69 \%)$ as a yellow oil; ${ }^{1} \mathrm{H}$ NMR $\left(300 \mathrm{MHz}, \mathrm{CDCl}_{3}\right) \delta 7.55(\mathrm{~d}$, $J=8.0 \mathrm{~Hz}, 2 \mathrm{H}), 7.28-7.25(\mathrm{~m}, 2 \mathrm{H}), 6.37(\mathrm{t}, J=2.3 \mathrm{~Hz}, 1 \mathrm{H}), 6.19(\mathrm{dt}, J$ $=2.3,1.3 \mathrm{~Hz}, 2 \mathrm{H}), 5.24-5.20(\mathrm{~m}, 1 \mathrm{H}), 4.13(\mathrm{~d}, J=7.0 \mathrm{~Hz}, 2 \mathrm{H}), 3.71(\mathrm{~s}$, $6 \mathrm{H}), 2.42(\mathrm{~s}, 3 \mathrm{H}), 2.10(\mathrm{~m}, 4 \mathrm{H}), 1.62(\mathrm{~s}, 3 \mathrm{H}) ;{ }^{13} \mathrm{C}\left\{{ }^{1} \mathrm{H}\right\}$ NMR $(75$ $\left.\mathrm{MHz}, \mathrm{CDCl}_{3}\right) \delta 160.7,143.5,141.2,138.2,135.8,129.5,127.9,121.5$, 107.1, 100.2, 79.7, 55.5, 48.6, 38.5, 30.6, 23.2, 21.7, 18.5; IR (neat) $\nu_{\max }$ 2925, 2839, 1592, 1457, 1347, 1204, 1152, 1065, $662 \mathrm{~cm}^{-1}$; HRMS (ESI) $m / z:[\mathrm{M}+\mathrm{Na}]^{+}$calcd for $\mathrm{C}_{23} \mathrm{H}_{26} \mathrm{BrNO}_{4} \mathrm{SNa}$ 514.0658; found 514.0651 .

(Z)-4-Methyl-N-(3-methylhept-2-en-6-yn-1-yl)-N-phenylbenzenesulfonamide $[(Z)-3 e]$. To a $0{ }^{\circ} \mathrm{C}$ solution of $(Z)-3$ methylhept-2-en-6-yn-1-ol ${ }^{26}(151.4 \mathrm{mg}, 1.21 \mathrm{mmol})$, triphenylphosphine $(479.2 \mathrm{mg}, 1.81 \mathrm{mmol})$ and $p$-toluene-sulfonanilide $(451.8 \mathrm{mg}$, $1.81 \mathrm{mmol})$ in THF $(15 \mathrm{~mL})$, DIAD $(0.36 \mathrm{~mL}, 1.81 \mathrm{mmol})$ was added dropwise. The reaction mixture was stirred for $5 \mathrm{~h}$ at $60^{\circ} \mathrm{C}$ in an oil bath and the solvent was evaporated in vacuo. The corresponding residue was purified by flash chromatography (10\% EtOAc/hexanes) to afford $(Z)$ 3e as a colorless oil (329.3 mg, $77 \%)$; ${ }^{1} \mathrm{H}$ NMR $\left(300 \mathrm{MHz}, \mathrm{CDCl}_{3}\right) \delta$ $7.49(\mathrm{~d}, J=8.3 \mathrm{~Hz}, 2 \mathrm{H}), 7.29-7.25(\mathrm{~m}, 5 \mathrm{H}), 7.05-7.02(\mathrm{~m}, 2 \mathrm{H})$, $5.24-5.19(\mathrm{~m}, 1 \mathrm{H}), 4.19(\mathrm{~d}, J=7.0 \mathrm{~Hz}, 2 \mathrm{H}), 2.43(\mathrm{~s}, 3 \mathrm{H}), 2.10-2.05$ $(\mathrm{m}, 4 \mathrm{H}), 1.89(\mathrm{t}, J=2.4 \mathrm{~Hz}, 1 \mathrm{H}), 1.61(\mathrm{~s}, 3 \mathrm{H}) ;{ }^{13} \mathrm{C}\left\{{ }^{1} \mathrm{H}\right\} \operatorname{NMR}(75$ $\left.\mathrm{MHz}, \mathrm{CDCl}_{3}\right) \delta 143.4,139.4,138.3,135.8,129.5,129.0,129.0,127.9$, 
$127.8,121.4,83.8,68.8,48.5,30.7,23.0,21.6,17.1$; IR (neat) $\nu_{\max } 3290$, 2920, 2869, 1596, 1493, 1345, 1162, 1092, $656 \mathrm{~cm}^{-1}$; HRMS (ESI) $\mathrm{m} /$ $z:[\mathrm{M}+\mathrm{Na}]^{+}$calcd for $\mathrm{C}_{21} \mathrm{H}_{23} \mathrm{NO}_{2} \mathrm{SNa} 376.1341$; found 376.1334.

(E)-N-(3,5-Dimethoxyphenyl)-N-(hept-2-en-6-yn-1-yl)-4methylbenzenesulfonamide $[(E)-3 f]$. To a $0{ }^{\circ} \mathrm{C}$ solution of $(E)$ hept-2-en-6-yn-1-ol ${ }^{28}(150.0 \mathrm{mg}, 1.36 \mathrm{mmol})$, triphenylphosphine (535.1 mg, $2.04 \mathrm{mmol})$, and $\mathrm{N}$-(3,5-dimethoxybenzyl)-4-methylbenzenesulfonamide $^{27}(627.0 \mathrm{mg}, 2.04 \mathrm{mmol})$ in THF $(10 \mathrm{~mL})$, DIAD $(0.40 \mathrm{~mL}, 2.04 \mathrm{mmol})$ was added dropwise and the reaction mixture was stirred for $5 \mathrm{~h}$ at $60^{\circ} \mathrm{C}$ in an oil bath. The solvent was evaporated in vacuo and the corresponding residue was purified by flash chromatography (20\% EtOAc/hexanes) to afford (E)-3f (396.6 g, $73 \%)$ as a white solid; mp $90-92{ }^{\circ} \mathrm{C} ;{ }^{1} \mathrm{H}$ NMR $\left(300 \mathrm{MHz}, \mathrm{CDCl}_{3}\right) \delta$ $7.53(\mathrm{~d}, J=8.2 \mathrm{~Hz}, 2 \mathrm{H}), 7.24(\mathrm{~d}, J=8.2 \mathrm{~Hz}, 2 \mathrm{H}), 6.35(\mathrm{t}, J=2.3 \mathrm{~Hz}$, $1 \mathrm{H}), 6.18(\mathrm{~d}, J=2.3 \mathrm{~Hz}, 2 \mathrm{H}), 5.56-5.40(\mathrm{~m}, 2 \mathrm{H}), 4.07(\mathrm{~d}, J=5.9 \mathrm{~Hz}$, $2 \mathrm{H}), 3.68(\mathrm{~s}, 6 \mathrm{H}), 2.40(\mathrm{~s}, 3 \mathrm{H}), 2.10(\mathrm{~m}, J=3.1,2.6 \mathrm{~Hz}, 4 \mathrm{H}), 1.87(\mathrm{~m}$, $1 \mathrm{H}) ;{ }^{13} \mathrm{C}\left\{{ }^{1} \mathrm{H}\right\} \mathrm{NMR}\left(75 \mathrm{MHz}, \mathrm{CDCl}_{3}\right) \delta 160.5,143.5,140.9,135.6$, 133.2, 129.4, 127.8, 125.8, 107.2, 100.1, 83.5, 68.8, 55.4, 52.9, 31.0, 21.6, 18.3; IR (neat) $\nu_{\max } 3289,2934,2840,1593,1458,1345,1153$, 1090, $662 \mathrm{~cm}^{-1}$; HRMS (ESI) $m / z:[\mathrm{M}+\mathrm{Na}]^{+}$calcd for $\mathrm{C}_{22} \mathrm{H}_{25} \mathrm{NO}_{4} \mathrm{SNa}$ 422.1396; found 422.1385 .

(Z)-4-Methoxy-2-(3-methylhept-2-en-6-yn-1-yl)phenol [(Z)5a]. $\mathrm{PBr}_{3}(162.4 \mathrm{mg}, 0.60 \mathrm{mmol})$ was added dropwise to a solution of $(Z)$-3-methylhept-2-en-6-yn-1-ol ${ }^{26}$ (150.2 mg, $1.21 \mathrm{mmol}$ ) in $\mathrm{Et}_{2} \mathrm{O}$ $(10 \mathrm{~mL})$ at $0{ }^{\circ} \mathrm{C}$ and was stirred for $30 \mathrm{~min}$. The reaction was quenched with $\mathrm{H}_{2} \mathrm{O}(10 \mathrm{~mL})$ and the aqueous phase was extracted with $\mathrm{Et}_{2} \mathrm{O}(3 \times$ $10 \mathrm{~mL})$. The combined organic phase was washed with $\mathrm{H}_{2} \mathrm{O}(30 \mathrm{~mL})$, $\mathrm{NaHCO}_{3}\left(30 \mathrm{~mL}\right.$, satd. sol.), and brine $(10 \mathrm{~mL})$, dried with $\mathrm{MgSO}_{4}$ (anhyd.), filtered, and concentrated in vacuo to afford (Z)-7-bromo-5methylhept-5-en-1-yne as an orange oil, which was used in the next step without further purification. The crude product was dissolved in toluene $(10 \mathrm{~mL})$ and $\mathrm{NaH} 95 \%(35.5 \mathrm{mg}, 1.33 \mathrm{mmol})$ and $4-$ methoxyphenol $(165.2 \mathrm{mg}, 1.33 \mathrm{mmol}$ ) was added. The reaction mixture was stirred overnight at room temperature, quenched with a $\mathrm{NH}_{4} \mathrm{Cl}$ saturated solution, and the aqueous phase was extracted with $\mathrm{Et}_{2} \mathrm{O}(3 \times 10 \mathrm{~mL})$. The resulting organic phase was washed with $\mathrm{H}_{2} \mathrm{O}$ $(30 \mathrm{~mL})$ and brine $(30 \mathrm{~mL})$, dried with $\mathrm{MgSO}_{4}$ (anhyd.), filtered, and concentrated in vacuo to yield, after purification by column chromatography (10\% EtOAc/hexanes), (Z)-5a (158.8 $\mathrm{mg}, 57 \%)$ as a colorless oil; ${ }^{1} \mathrm{H}$ NMR $\left(300 \mathrm{MHz}, \mathrm{CDCl}_{3}\right) \delta 6.73(\mathrm{~d}, J=8.5 \mathrm{~Hz}, 1 \mathrm{H})$, 6.68-6.64 (m, 2H), 5.41-5.36 (m, 1H), $4.68(\mathrm{~s}, 1 \mathrm{H}), 3.75(\mathrm{~s}, 3 \mathrm{H})$, $3.37(\mathrm{~d}, J=7.1 \mathrm{~Hz}, 2 \mathrm{H}), 2.42-2.40(\mathrm{~m}, 2 \mathrm{H}), 2.38-2.35(\mathrm{~m}, 2 \mathrm{H}), 1.99$ $(\mathrm{t}, J=2.5 \mathrm{~Hz}, 1 \mathrm{H}), 1.78(\mathrm{~s}, 3 \mathrm{H}) ;{ }^{13} \mathrm{C}\left\{{ }^{1} \mathrm{H}\right\} \operatorname{NMR}\left(75 \mathrm{MHz}, \mathrm{CDCl}_{3}\right) \delta$ $153.7,148.1,136.2,128.2,124.2,116.3,115.9,112.1,84.1,68.9,55.9$, 30.8, 29.6, 23.1, 17.2; IR (neat) $\nu_{\max } 3405,3290,2913,2834,1497$, 1430, 1199, 1039, $803 \mathrm{~cm}^{-1}$; HRMS (EI) $\mathrm{m} / z:[\mathrm{M}]^{+}$calcd for $\mathrm{C}_{15} \mathrm{H}_{18} \mathrm{O}_{2}$ 230.1301; found 230.1296.

(Z)-2-(7-Bromo-3-methylhept-2-en-6-yn-1-yl)-4-methoxyphenol $[(Z)-5 b]$. To a room temperature solution of (Z)-3methylhept-2-en-6-yn-1-ol ${ }^{26}(84.8 \mathrm{mg}, 0.68 \mathrm{mmol})$ in acetone (5 $\mathrm{mL})$, NBS (133.8 mg, $0.75 \mathrm{mmol}$ ) and $\mathrm{AgNO}_{3}(12.7 \mathrm{mg}, 0.07 \mathrm{mmol})$ were added, and the reaction mixture was stirred for $1 \mathrm{~h}$. The reaction mixture was diluted with $\mathrm{Et}_{2} \mathrm{O}(10 \mathrm{~mL})$, washed with $\mathrm{H}_{2} \mathrm{O}(10 \mathrm{~mL})$ and brine $(10 \mathrm{~mL})$, dried with $\mathrm{MgSO}_{4}$ (anhyd.), filtered, and concentrated in vacuo to afford (Z)-7-bromo-3-methylhept-2-en-6-yn-1-ol as an orange oil, which was used in the next step without further purification. The crude product was dissolved in $\mathrm{Et}_{2} \mathrm{O}(10 \mathrm{~mL})$ and cooled at $0{ }^{\circ} \mathrm{C}$, $\mathrm{PBr}_{3}$ (92.4 $\mathrm{mg}, 0.34 \mathrm{mmol}$ ) was then added dropwise, and the reaction mixture was stirred for $30 \mathrm{~min}$. The reaction was quenched with $\mathrm{H}_{2} \mathrm{O}$ $(10 \mathrm{~mL})$, and the aqueous phase was extracted with $\mathrm{Et}_{2} \mathrm{O}(3 \times 10 \mathrm{~mL})$. The resulting organic phase was washed with $\mathrm{H}_{2} \mathrm{O}(30 \mathrm{~mL})$, a $\mathrm{NaHCO}_{3}$ saturated solution $(30 \mathrm{~mL})$, and brine $(10 \mathrm{~mL})$, dried with $\mathrm{MgSO}_{4}$ (anhyd.), filtered, and concentrated in vacuo to afford (Z)-1,7-dibromo5-methylhept-5-en-1-yne as an orange oil, which was used in the next step without further purification.

The crude product in toluene $(10 \mathrm{~mL})$ was added to a solution of $\mathrm{NaH} 95 \%$ (20.0 mg, $0.75 \mathrm{mmol}$ ) and 4-methoxyphenol (92.9 mg, 0.75 $\mathrm{mmol}$ ) at room temperature, and the reaction mixture was stirred overnight. The reaction mixture was quenched with a $\mathrm{NH}_{4} \mathrm{Cl}$ saturated solution $(2 \mathrm{~mL})$ and was extracted with $\mathrm{Et}_{2} \mathrm{O}(3 \times 10 \mathrm{~mL})$. The combined organic phase was washed with $\mathrm{H}_{2} \mathrm{O}(30 \mathrm{~mL})$ and brine $(30$ $\mathrm{mL}$ ), dried with $\mathrm{MgSO}_{4}$ (anhyd.), filtered, and concentrated in vacuo to afford, after purification by column chromatography (10\% EtOAc/ hexanes), (Z)-5b (90.4 mg, 43\%) as a colorless oil; ${ }^{1} \mathrm{H}$ NMR (300 $\left.\mathrm{MHz} \mathrm{CDCl}_{3}\right) \delta 6.74-6.63(\mathrm{~m}, 3 \mathrm{H}), 5.42-5.38(\mathrm{~m}, 1 \mathrm{H}), 4.89(\mathrm{~s}, 1 \mathrm{H})$, $3.76(\mathrm{~s}, 3 \mathrm{H}), 3.36(\mathrm{~d}, J=7.2 \mathrm{~Hz}, 2 \mathrm{H}), 2.40-2.35(\mathrm{~m}, 4 \mathrm{H}), 1.77(\mathrm{~s}, 3 \mathrm{H})$; ${ }^{13} \mathrm{C}\left\{{ }^{1} \mathrm{H}\right\}$ NMR $\left(75 \mathrm{MHz}, \mathrm{CDCl}_{3}\right) \delta 153.7,148.0,135.9,128.3,124.2$, 116.2, 115.8, 112.1, 79.9, 55.9, 38.5, 30.7, 29.3, 23.3, 18.6; IR (neat) $\nu_{\max } 3408,2915,2835,1504,1432,1201,1041,805 \mathrm{~cm}^{-1}$; HRMS (ESI) $m / z:[\mathrm{M}+\mathrm{Na}]^{+}$calcd for $\mathrm{C}_{15} \mathrm{H}_{17} \mathrm{BrO}_{2} \mathrm{Na}$ : 331.0304; found 331.0315.

General Procedure for In(III)-Catalyzed Cascade Cycloisomerization Reactions of 1,5-Enynes. In a Schlenk tube filled with argon, $\operatorname{InI}_{3}(5 \mathrm{~mol} \%)$ was placed and a solution of the corresponding 1,5-enyne $(\sim 0.07 \mathrm{M})$ in toluene was added. The reaction mixture was stirred at $60^{\circ} \mathrm{C}$ in an oil bath (for $1 \mathbf{a}-\mathbf{d}, 3 \mathbf{a}-\mathbf{f}$, and $7 \mathbf{a}-\mathbf{c}$ ) or at room temperature (for $\mathbf{5 a}-\mathbf{b}$ ) until the starting material is consumed (TLC). The reaction was quenched with $\mathrm{NH}_{4} \mathrm{Cl}(10 \mathrm{~mL}$, satd. sol.), poured into a separatory funnel, and the aqueous phase was extracted with $\mathrm{Et}_{2} \mathrm{O}(3 \times 10 \mathrm{~mL})$. The resulting combined organic phase was washed with brine $(15 \mathrm{~mL})$, dried with anhydrous $\mathrm{MgSO}_{4}$, filtered, and concentrated under reduced pressure to afford, after purification by column chromatography, the corresponding tricyclic product.

$\left(6 a S^{*}, 10 a S^{*}\right)-1,3-$ Dimethoxy-10a-methyl-6a,9,10,10a-tetrahydro- $6 \mathrm{H}$-benzo[c]chromene [trans-2a]. ${ }^{4 c}$ According to the general procedure, the reaction of 1,5-enyne $(E)-1 \mathrm{a}(87.4 \mathrm{mg}, 0.34$ mmol) with $\mathrm{InI}_{3}(8.5 \mathrm{mg}, 0.017 \mathrm{mmol})$ gave $2 \mathrm{a}(56.8 \mathrm{mg}, 65 \%$; cis/ trans $=11: 89)$ as a colorless oil. Purification by column chromatography (2\% EtOAc/hexanes) provided pure trans-2a: ${ }^{1} \mathrm{H}$ NMR (300 $\left.\mathrm{MHz}, \mathrm{CDCl}_{3}\right) \delta 6.05-6.02(\mathrm{~m}, 2 \mathrm{H}), 5.82-5.76(\mathrm{~m}, 1 \mathrm{H}), 5.36(\mathrm{dq}, J=$ 9.8, $2.1 \mathrm{~Hz}, 1 \mathrm{H}), 4.08(\mathrm{dd}, J=10.3,4.1 \mathrm{~Hz}, 1 \mathrm{H}), 3.99$ (dd, $J=12.4,10.3$ $\mathrm{Hz}, 1 \mathrm{H}), 3.77(\mathrm{~s}, 3 \mathrm{H}), 3.74(\mathrm{~s}, 3 \mathrm{H}), 3.07-3.00(\mathrm{~m}, 1 \mathrm{H}), 2.71-2.67(\mathrm{~m}$, $1 \mathrm{H}), 2.22(\mathrm{~m}, 2 \mathrm{H}), 1.57-1.53(\mathrm{~m}, 1 \mathrm{H}), 1.17(\mathrm{~s}, 3 \mathrm{H}) ;{ }^{13} \mathrm{C}\left\{{ }^{1} \mathrm{H}\right\} \mathrm{NMR}$ $\left(75 \mathrm{MHz}, \mathrm{CDCl}_{3}\right) \delta 160.3,159.3,155.8,129.3,123.8,113.8,94.1,92.3$, $66.4,55.3,55.3,41.7,33.3,32.0,24.4,18.1$. HRMS (ESI) $m / z:[\mathrm{M}+$ $\mathrm{Na}]^{+}$calcd for $\mathrm{C}_{16} \mathrm{H}_{20} \mathrm{O}_{3} \mathrm{Na}$ 283.1304; found 283.1317.

Scale-Up Experiment for (trans)-2a. In a Schlenk tube filled with argon, $\mathrm{InI}_{3}(38.1 \mathrm{mg}, 0.077 \mathrm{mmol})$ was placed and a solution of the enyne $(E)-1 \mathrm{a}(400.5 \mathrm{mg}, 1.54 \mathrm{mmol})$ in toluene $(22 \mathrm{~mL})$ was added. The reaction mixture was stirred at $60{ }^{\circ} \mathrm{C}$ in an oil bath for $2 \mathrm{~h}$, quenched with a $\mathrm{NH}_{4} \mathrm{Cl}(30 \mathrm{~mL}$, satd. sol.), poured into a separatory funnel, and extracted with $\mathrm{Et}_{2} \mathrm{O}(3 \times 30 \mathrm{~mL})$. The combined organic phase was washed with brine $(35 \mathrm{~mL})$, dried with anhydrous $\mathrm{MgSO}_{4}$, filtered, and concentrated under reduced pressure. The residue was purified by column chromatography ( $2 \%$ EtOAc/hexanes) to afford 2a $(252.4 \mathrm{mg}, 63 \%$; cis $/$ trans $=16: 84)$ as a colorless oil.

(4aS*,9a $\left.S^{*}\right)-6,8-D i m e t h o x y-4 a-m e t h y l-4,4 a, 9,9 a-t e t r a h y-$ dro-3H-xanthene (I). According to the general procedure, the reaction of 1,5 -enyne $(E)-1 \mathrm{a}(150.2 \mathrm{mg}, 0.58 \mathrm{mmol})$ with $\mathrm{InI}_{3}(14.3$ $\mathrm{mg}, 0.029 \mathrm{mmol})$ in the presence of $\mathrm{AgSbF}_{6}(10.0 \mathrm{mg}, 0.029 \mathrm{mmol})$ afforded a mixture of I:2a $(4: 1)$ by ${ }^{1} \mathrm{H}$ NMR. After purification by column chromatography (1\% EtOAc/hexanes), compound I was isolated as a colorless oil $(81.1 \mathrm{mg}, 54 \%$, cis/trans $=19: 81) ;{ }^{1} \mathrm{H}$ NMR $\left(500 \mathrm{MHz}, \mathrm{CDCl}_{3}\right) \delta 6.05(\mathrm{~d}, J=0.9 \mathrm{~Hz}, 2 \mathrm{H}), 5.66-5.64(\mathrm{~m}, 1 \mathrm{H}), 5.52$ (ddt, $J=9.7,2.5,1.7 \mathrm{~Hz}, 1 \mathrm{H}), 3.79(\mathrm{~s}, 3 \mathrm{H}), 3.75(\mathrm{~s}, 3 \mathrm{H}), 2.72(\mathrm{dd}, J=$ $16.2,5.5 \mathrm{~Hz}, 1 \mathrm{H}), 2.50-2.42(\mathrm{~m}, 1 \mathrm{H}), 2.35-2.28(\mathrm{~m}, 1 \mathrm{H}), 2.27-2.18$ $(\mathrm{m}, 1 \mathrm{H}), 2.11(\mathrm{dd}, J=16.2,13.7 \mathrm{~Hz}, 1 \mathrm{H}), 1.98-1.92(\mathrm{~m}, 1 \mathrm{H}), 1.86(\mathrm{td}$, $J=12.0,6.9 \mathrm{~Hz}, 1 \mathrm{H}), 1.11(\mathrm{~s}, 3 \mathrm{H}) .{ }^{13} \mathrm{C}\left\{{ }^{1} \mathrm{H}\right\} \mathrm{NMR}\left(126 \mathrm{MHz}, \mathrm{CDCl}_{3}\right)$ $\delta 159.5,158.5,154.9,128.8,126.5,104.0,93.8,91.0,75.9,55.4,55.3$, 38.6, 35.2, 25.1, 22.3, 15.9. HRMS (ESI) $\mathrm{m} / z:[\mathrm{M}+\mathrm{H}]^{+}$calcd for $\mathrm{C}_{16} \mathrm{H}_{21} \mathrm{O}_{3}$ 261.1491; found 261.1486.

2-(But-3-yn-1-yl)-5,7-dimethoxy-2-methylchromane (II). According to the general procedure, the reaction of 1,5-enyne $(E)-1$ a $(90.1 \mathrm{mg}, 0.35 \mathrm{mmol})$ with $\operatorname{In}\left(\mathrm{NTf}_{2}\right)_{3}(16.7 \mathrm{mg}, 0.018 \mathrm{mmol})$ in DCE $(5 \mathrm{~mL})$ at $60{ }^{\circ} \mathrm{C}$ in an oil bath for $5 \mathrm{~h}$ afforded, after purification by column chromatography (5\% EtOAc/hexanes), compound II (56.7 $\mathrm{mg}, 63 \%)$ as a yellow oil; ${ }^{1} \mathrm{H} \mathrm{NMR}\left(400 \mathrm{MHz}, \mathrm{CDCl}_{3}\right) \delta 6.03(\mathrm{~d}, J=2.4$ $\mathrm{Hz}, 1 \mathrm{H}), 5.99(\mathrm{~d}, J=2.4 \mathrm{~Hz}, 1 \mathrm{H}), 3.78(\mathrm{~s}, 3 \mathrm{H}), 3.75(\mathrm{~s}, 3 \mathrm{H}), 2.64-2.49$ $(\mathrm{m}, 2 \mathrm{H}), 2.37-2.32(\mathrm{~m}, 2 \mathrm{H}), 1.97-1.91(\mathrm{~m}, 2 \mathrm{H}), 1.86-1.82(\mathrm{~m}, 1 \mathrm{H})$, $1.79-1.73(\mathrm{~m}, 2 \mathrm{H}), 1.28(\mathrm{~s}, 3 \mathrm{H}) ;{ }^{13} \mathrm{C}\left\{{ }^{1} \mathrm{H}\right\} \operatorname{NMR}\left(101 \mathrm{MHz} \mathrm{CDCl}_{3}\right) \delta$ 
159.6, 158.6, 154.8, 102.5, 93.8, 91.1, 84.8, 75.3, 68.3, 55.5, 55.4, 38.4, $30.8,23.8,16.3,13.1$; IR (neat) $\nu_{\max } 3289,2926,2853,1616,1590$, $1202,1143,1105,811 \mathrm{~cm}^{-1}$; HRMS (ESI) $\mathrm{m} / z:[\mathrm{M}+\mathrm{Na}]^{+}$calcd for $\mathrm{C}_{16} \mathrm{H}_{20} \mathrm{NaO}_{3}$ 283.1304; found 283.1317.

$\left(6 a S^{*}, 10 a S^{*}\right)-1,3-D i m e t h o x y-7,10 a-d i m e t h y l-6 a, 9,10,10 a-$ tetrahydro-6H-benzo[c]chromene [trans-2b]. ${ }^{1 \mathrm{a} a}$ According to the general procedure, the reaction of 1,5-enyne $(E)-1 \mathbf{b}(99.2 \mathrm{mg}, 0.36$ $\mathrm{mmol})$ with $\mathrm{InI}_{3}(8.9 \mathrm{mg}, 0.018 \mathrm{mmol})$ afforded $\mathbf{2 b}(67.5 \mathrm{mg}, 68 \%$; cis/ trans $=22: 78)$ as a colorless oil. Purification by column chromatography (2\% EtOAc/hexanes) afforded pure trans-2b: ${ }^{1} \mathrm{H}$ NMR (300 $\left.\mathrm{MHz}, \mathrm{CDCl}_{3}\right) \delta 6.04-6.01(\mathrm{~m}, 2 \mathrm{H}), 5.46(\mathrm{~m}, 1 \mathrm{H}), 4.38(\mathrm{dd}, J=10.4$, $3.6 \mathrm{~Hz}, 1 \mathrm{H}), 4.01-3.94(\mathrm{~m}, 1 \mathrm{H}), 3.76(\mathrm{~s}, 3 \mathrm{H}), 3.74(\mathrm{~s}, 3 \mathrm{H}), 3.00(\mathrm{dd}, J$ $=13.1,6.1 \mathrm{~Hz}, 1 \mathrm{H}), 2.66(\mathrm{~d}, J=12.1 \mathrm{~Hz}, 1 \mathrm{H}), 2.14(\mathrm{~m}, 2 \mathrm{H}), 1.67(\mathrm{~s}$, $3 \mathrm{H}), 1.49-1.41(\mathrm{~m}, 1 \mathrm{H}) 1.18(\mathrm{~s}, 3 \mathrm{H}) ;{ }^{13} \mathrm{C}\left\{{ }^{1} \mathrm{H}\right\}$ NMR $(101 \mathrm{MHz}$, $\left.\mathrm{CDCl}_{3}\right) \delta 160.3,159.3,155.7,130.0,123.5,113.8,93.9,92.4,64.4,55.3$, $55.3,44.7,33.7,31.9,23.7,20.8,18.4$; HRMS (ESI) $m / z:[\mathrm{M}+\mathrm{Na}]^{+}$ calcd for $\mathrm{C}_{17} \mathrm{H}_{22} \mathrm{O}_{3} \mathrm{Na}$ 297.1461; found 297.1454.

(6aS*,10aS*)-7-Bromo-1,3-dimethoxy-10a-methyl$6 a, 9,10,10 a-t e t r a h y d r o-6 H$-benzo[c]chromene [trans-2c]. According to the general procedure, the reaction of 1,5-enyne $(E)-1 \mathrm{c}$ $(68.6 \mathrm{mg}, 0.20 \mathrm{mmol})$ with $\operatorname{InI}_{3}(5.0 \mathrm{mg}, 0.010 \mathrm{mmol})$ afforded $2 \mathrm{c}(42.5$ $\mathrm{mg}, 62 \%$; cis/trans $=27: 73)$ as a white solid. Purification by column chromatography (2\% EtOAc/hexanes) afforded pure trans-2c: ${ }^{1} \mathrm{H}$ NMR $\left(300 \mathrm{MHz}, \mathrm{CDCl}_{3}\right) \delta 6.18-6.16(\mathrm{~m}, 1 \mathrm{H}), 6.05-6.02(\mathrm{~m}, 2 \mathrm{H})$, $4.57(\mathrm{dd}, J=10.4,3.5 \mathrm{~Hz}, 1 \mathrm{H}), 3.95(\mathrm{dd}, \mathrm{J}=11.8,10.4 \mathrm{~Hz}, 1 \mathrm{H}), 3.76(\mathrm{~s}$, $3 \mathrm{H}), 3.74(\mathrm{~s}, 3 \mathrm{H}), 3.14-3.07(\mathrm{~m}, 1 \mathrm{H}), 2.99-2.93(\mathrm{~m}, 1 \mathrm{H}), 2.26-2.22$ $(\mathrm{m}, 2 \mathrm{H}), 1.49(\mathrm{~m}, 1 \mathrm{H}), 1.25(\mathrm{~s}, 3 \mathrm{H}) ;{ }^{13} \mathrm{C}\left\{{ }^{1} \mathrm{H}\right\}$ NMR $(126 \mathrm{MHz}$, $\left.\mathrm{CDCl}_{3}\right) \delta 159.9,159.5,155.8,131.1,119.7,112.4,93.9,92.5,66.2,55.4$, $55.3,46.8,36.3,31.3,26.2,18.5$; IR (neat) $\nu_{\max } 2933,2837,1612,1583$, $1463,1201,1151,1104,814 \mathrm{~cm}^{-1}$; HRMS (ESI) $\mathrm{m} / z:[\mathrm{M}+\mathrm{Na}]^{+}$calcd for $\mathrm{C}_{16} \mathrm{H}_{19} \mathrm{BrO}_{3} \mathrm{Na} 361.0409$; found 361.0418 .

$\left(6 \mathrm{a} R *, 10 \mathrm{a} \mathrm{S}^{*}\right)-10 \mathrm{a}-\mathrm{Methyl}-6 \mathrm{a}, 9,10,10 \mathrm{a}$-tetrahydro-6Hbenzo[c]chromene [cis-2d]. According to the general procedure, the reaction of 1,5-enyne $(E)-1 \mathrm{~d}(105.4 \mathrm{mg}, 0.53 \mathrm{mmol})$ with $\mathrm{InI}_{3}(13.0$ $\mathrm{mg}, 0.027 \mathrm{mmol})$ or 1,5 -enyne $(Z)-1 \mathrm{~d}(99.2 \mathrm{mg}, 0.49)$ with $\mathrm{InI}_{3}(11.8$ $\mathrm{mg}, 0.025 \mathrm{mmol}$ ) afforded cis-2d [64.3 mg, 61\% from (E)-1d and 64.5 $\mathrm{mg}, 65 \%$ from $(Z)-1 \mathrm{~d}]$ as a yellow oil after purification by column chromatography (2\% EtOAc/hexanes); ${ }^{1} \mathrm{H} \mathrm{NMR}\left(300 \mathrm{MHz}, \mathrm{CDCl}_{3}\right)$ $\delta 7.23(\mathrm{dd}, J=7.8,1.7 \mathrm{~Hz}, 1 \mathrm{H}), 7.08(\mathrm{ddd}, J=8.0,7.2,1.7 \mathrm{~Hz}, 1 \mathrm{H}), 6.90$ $(\mathrm{td}, J=7.5,1.3 \mathrm{~Hz}, 1 \mathrm{H}), 6.79(\mathrm{dd}, J=8.1,1.4 \mathrm{~Hz}, 1 \mathrm{H}), 5.82-5.79(\mathrm{~m}$, $1 \mathrm{H}), 5.59(\mathrm{ddt}, J=10.0,3.8,2.0 \mathrm{~Hz}, 1 \mathrm{H}), 4.22(\mathrm{dd}, J=11.0,3.0 \mathrm{~Hz}$, $1 \mathrm{H}), 3.90(\mathrm{dd}, J=11.0,6.6 \mathrm{~Hz}, 1 \mathrm{H}), 2.34(\mathrm{~m}, 1 \mathrm{H}), 2.02-1.98(\mathrm{~m}, 2 \mathrm{H})$, $1.88-1.68(\mathrm{~m}, 2 \mathrm{H}), 1.35(\mathrm{~s}, 3 \mathrm{H}) ;{ }^{13} \mathrm{C}\left\{{ }^{1} \mathrm{H}\right\}$ NMR $\left(75 \mathrm{MHz}, \mathrm{CDCl}_{3}\right) \delta$ 154.3, 130.4, 129.9, 127.3, 127.1, 126.1, 120.9, 117.0, 66.8, 41.3, 33.9, 32.9, 29.1, 22.6; IR (neat) $\nu_{\text {max }} 2922,2855,1579,1488,1447,1218,751$ $\mathrm{cm}^{-1}$; HRMS (EI) $\mathrm{m} / z$ : $[\mathrm{M}]^{+}$calcd for $\mathrm{C}_{14} \mathrm{H}_{16} \mathrm{O}$ 200.1201; found 200.1182 .

$\left(6 \mathrm{a} R^{*}, 10 \mathrm{a} S^{*}\right)-1,3-D i m e t h o x y-10 \mathrm{a}-\mathrm{methyl}-6 \mathrm{a}, 9,10,10 \mathrm{a}$-tetrahydro- $6 \mathrm{H}$-benzo[c]chromene [cis-2a]. According to the general procedure, the reaction of 1,5 -enyne $(Z)-1 \mathrm{a}(91.5 \mathrm{mg}, 0.35 \mathrm{mmol})$ with $\mathrm{InI}_{3}(9.1 \mathrm{mg}, 0.018 \mathrm{mmol})$ afforded cis-2a $(58.6 \mathrm{mg}, 64 \%)$ as a colorless oil after purification by column chromatography ( $2 \%$ EtOAc/hexanes); ${ }^{1} \mathrm{H}$ NMR $\left(300 \mathrm{MHz}, \mathrm{CDCl}_{3}\right) \delta 6.07(\mathrm{~d}, J=2.6 \mathrm{~Hz}, 1 \mathrm{H}), 6.01(\mathrm{~d}, J=2.6$ $\mathrm{Hz}, 1 \mathrm{H}), 5.84-5.81(\mathrm{~m}, 1 \mathrm{H}), 5.51(\mathrm{ddt}, J=9.9,3.6,1.8 \mathrm{~Hz}, 1 \mathrm{H}), 4.13$ $(\mathrm{dd}, J=10.7,2.8 \mathrm{~Hz}, 1 \mathrm{H}), 3.84(\mathrm{dd}, J=10.7,6.8 \mathrm{~Hz}, 1 \mathrm{H}), 3.77(\mathrm{~s}, 3 \mathrm{H})$, $3.74(\mathrm{~s}, 3 \mathrm{H}), 2.26-2.24(\mathrm{~m}, 1 \mathrm{H}), 2.22-2.18(\mathrm{~m}, 1 \mathrm{H}), 1.99-1.78(\mathrm{~m}$, $3 \mathrm{H}), 1.39(\mathrm{~s}, 3 \mathrm{H}) ;{ }^{13} \mathrm{C}\left\{{ }^{1} \mathrm{H}\right\}$ NMR $\left(75 \mathrm{MHz}, \mathrm{CDCl}_{3}\right) \delta 160.7,159.0$, $156.5,130.5,125.9,111.0,93.7,92.9,66.8,55.3,55.3,43.4,33.2,30.8$, 25.7, 23.0; IR (neat) $\nu_{\max } 2922,2837,1612,1583,1463,1200,1153$, $814 \mathrm{~cm}^{-1}$; HRMS (EI) $\mathrm{m} / z$ : $[\mathrm{M}]^{+}$calcd for $\mathrm{C}_{16} \mathrm{H}_{20} \mathrm{O}_{3} 260.1407$; found 260.1402 .

(6a $\left.R^{*}, 10 \mathrm{a} S *\right)-7-$ Bromo-1,3-dimethoxy-10a-methyl6a,9,10,10a-tetrahydro-6H-benzo[c]chromene [cis-2c]. According to the general procedure, the reaction of 1,5-enyne $(Z)-1 \mathrm{c}(84.0 \mathrm{mg}$, $0.25 \mathrm{mmol})$ with $\operatorname{InI}_{3}(6.1 \mathrm{mg}, 0.012 \mathrm{mmol})$ afforded cis-2c $(47.9 \mathrm{mg}$, $57 \%)$ as a yellow oil after purification by column chromatography $(2 \%$ EtOAc/hexanes); ${ }^{1} \mathrm{H}$ NMR $\left(300 \mathrm{MHz}, \mathrm{CDCl}_{3}\right) \delta 6.21(\mathrm{~m}, 1 \mathrm{H}), 6.07$ $(\mathrm{d}, J=2.6 \mathrm{~Hz}, 1 \mathrm{H}), 6.05(\mathrm{~d}, J=2.6 \mathrm{~Hz}, 1 \mathrm{H}), 4.32(\mathrm{dd}, J=10.9,2.9 \mathrm{~Hz}$, $1 \mathrm{H}), 4.06(\mathrm{dd}, J=10.9,8.0 \mathrm{~Hz}, 1 \mathrm{H}), 3.77(\mathrm{~s}, 3 \mathrm{H}), 3.74(\mathrm{~s}, 3 \mathrm{H}), 2.52-$ $2.49(\mathrm{~m}, 1 \mathrm{H}), 2.03(\mathrm{~m}, 3 \mathrm{H}), 1.89(\mathrm{~m}, 1 \mathrm{H}), 1.44(\mathrm{~s}, 3 \mathrm{H}) ;{ }^{13} \mathrm{C}\left\{{ }^{1} \mathrm{H}\right\} \mathrm{NMR}$ $\left(101 \mathrm{MHz}, \mathrm{CDCl}_{3}\right) \delta 160.3,159.4,156.7,132.5,121.6,110.9,93.9$, 93.3, 65.8, 55.3, 51.3, 36.2, 29.2, 25.1, 24.8; IR (neat) $\nu_{\max } 2935,2837$, $1612,1584,1464,1201,1153,815 \mathrm{~cm}^{-1}$; HRMS (EI) $\mathrm{m} / z:[\mathrm{M}]^{+}$calcd for $\mathrm{C}_{16} \mathrm{H}_{19} \mathrm{BrO}_{3}$ 338.0512; found 338.0511 .

(6a $S *, 10$ a $S *)-1,3$-Dimethoxy-10a-methyl-5-tosyl$5,6,6 a, 9,10,10 a-h e x a h y d r o p h e n a n t h r i d i n e ~[t r a n s-4 a] .^{14 c}$ According to the general procedure, the reaction of 1,5-enyne $(E)-3 \mathbf{a}$ $(120.0 \mathrm{mg}, 0.29 \mathrm{mmol})$ with $\mathrm{InI}_{3}(7.2 \mathrm{mg}, 0.015 \mathrm{mmol})$ afforded, after purification by column chromatography ( $5 \%$ EtOAc/hexanes), trans4a $(108.1 \mathrm{mg}, 90 \%)$ as a white solid; ${ }^{1} \mathrm{H}$ NMR $\left(300 \mathrm{MHz}, \mathrm{CDCl}_{3}\right) \delta$ $7.51(\mathrm{~d}, J=8.3,2 \mathrm{H}), 7.21-7.17(\mathrm{~m}, 3 \mathrm{H}), 6.22(\mathrm{~d}, J=2.5,1 \mathrm{H}), 5.71(\mathrm{dq}$, $J=9.9,3.3 \mathrm{~Hz}, 1 \mathrm{H}), 5.33(\mathrm{dq}, J=9.8,2.1 \mathrm{~Hz}, 1 \mathrm{H}), 4.00(\mathrm{dd}, J=11.9,4.2$ $\mathrm{Hz}, 1 \mathrm{H}), 3.80(\mathrm{~s}, 3 \mathrm{H}), 3.72(\mathrm{~s}, 3 \mathrm{H}), 3.22(\mathrm{dd}, J=13.6,11.8 \mathrm{~Hz}, 1 \mathrm{H})$, $2.99(\mathrm{dt}, J=13.3,4.1 \mathrm{~Hz}, 1 \mathrm{H}), 2.36(\mathrm{~s}, 3 \mathrm{H}), 2.30(\mathrm{~m}, 1 \mathrm{H}), 2.10-2.05$ (m, 2H), 1.30-1.29 (m, 1H), $0.66(\mathrm{~s}, 3 \mathrm{H}) ;{ }^{13} \mathrm{C}\left\{{ }^{1} \mathrm{H}\right\} \mathrm{NMR}(75 \mathrm{MHz}$, $\left.\mathrm{CDCl}_{3}\right) \delta 159.3,158.2,143.8,137.9,135.8,129.6,128.8,127.4,125.0$, $120.4,100.4,96.3,55.5,55.4,47.9,41.0,35.2,31.9,23.9,21.6,16.4$; HRMS (ESI) $m / z:[\mathrm{M}+\mathrm{Na}]^{+}$calcd for $\mathrm{C}_{23} \mathrm{H}_{27} \mathrm{NO}_{4} \mathrm{SNa} 436.1553$; found 436.1559 .

(6aS*,10aS*)-1,3-Dimethoxy-7,10a-dimethyl-5-tosyl$5,6,6 a, 9,10,10 a-h e x a h y d r o p h e n a n t h r i d i n e$ [trans-4b]. According to the general procedure, the reaction of 1,5-enyne $(E)-3 \mathbf{b}(48.8 \mathrm{mg}$, $0.11 \mathrm{mmol})$ with $\mathrm{InI}_{3}(2.8 \mathrm{mg}, 0.006 \mathrm{mmol})$ afforded, after purification by column chromatography ( $5 \%$ EtOAc/hexanes), trans $-4 \mathbf{b}$ ( $41.5 \mathrm{mg}$, $85 \%)$ as a white solid; ${ }^{1} \mathrm{H}$ NMR $\left(300 \mathrm{MHz}, \mathrm{CDCl}_{3}\right) \delta 7.53(\mathrm{~d}, J=8.3$ $\mathrm{Hz}, 2 \mathrm{H}), 7.21-7.17(\mathrm{~m}, 3 \mathrm{H}), 6.24(\mathrm{~d}, J=2.5 \mathrm{~Hz}, 1 \mathrm{H}), 5.39(\mathrm{~m}, 1 \mathrm{H})$, $4.38(\mathrm{dd}, J=12.6,3.6 \mathrm{~Hz}, 1 \mathrm{H}), 3.80(\mathrm{~s}, 3 \mathrm{H}), 3.72(\mathrm{~s}, 3 \mathrm{H}), 3.20(\mathrm{t}, J=$ $12.8 \mathrm{~Hz}, 1 \mathrm{H}), 2.93(\mathrm{dd}, J=13.1,6.2 \mathrm{~Hz}, 1 \mathrm{H}), 2.36(\mathrm{~s}, 3 \mathrm{H}), 2.22-2.18$ $(\mathrm{m}, 1 \mathrm{H}), 2.05-1.98(\mathrm{~m}, 2 \mathrm{H}), 1.70(\mathrm{~s}, 3 \mathrm{H}), 1.15-1.07(\mathrm{~m}, 1 \mathrm{H}), 0.80(\mathrm{~s}$, $3 \mathrm{H}) ;{ }^{13} \mathrm{C}\left\{{ }^{1} \mathrm{H}\right\}$ NMR $\left(75 \mathrm{MHz}, \mathrm{CDCl}_{3}\right) \delta 159.5,158.1,143.8,137.7$, 136.3, 130.8, 129.6, 127.4, 123.3, 120.4, 100.4, 96.6, 55.5, 55.4, 45.2, 44.1, 35.9, 31.9, 23.5, 21.7, 21.2, 17.1; IR (neat) $\nu_{\max } 2926,2839,1606$, $1581,1455,1350,1187,1164,671 \mathrm{~cm}^{-1}$; HRMS (ESI) $m / z:[\mathrm{M}+\mathrm{Na}]^{+}$ calcd for $\mathrm{C}_{24} \mathrm{H}_{29} \mathrm{NO}_{4} \mathrm{SNa} 450.1709$; found 450.1705 .

$\left(6 \mathrm{a} R^{*}, 10 \mathrm{a} S^{*}\right)-1,3-D i m e t h o x y-10 a-m e t h y l-7-p h e n y l-5-t o s y l-$ 5,6,6a,9,10,10a-hexahydrophenanthridine [trans-4c]. According to the general procedure, the reaction of 1,5 -enyne $(E)-3 \mathrm{c}(80.9 \mathrm{mg}$, $0.17 \mathrm{mmol})$ with $\mathrm{InI}_{3}(4.2 \mathrm{mg}, 0.008 \mathrm{mmol})$ afforded trans $-4 \mathrm{c}(66.3 \mathrm{mg}$, $82 \%)$ as a white solid after purification by column chromatography $(5 \%$ EtOAc/hexanes); ${ }^{1} \mathrm{H}$ NMR $\left(300 \mathrm{MHz}, \mathrm{CDCl}_{3}\right) \delta 7.51(\mathrm{~d}, J=8.3 \mathrm{~Hz}$, $2 \mathrm{H}), 7.36-7.28(\mathrm{~m}, 3 \mathrm{H}), 7.21-7.11(\mathrm{~m}, 4 \mathrm{H}), 7.13(\mathrm{~d}, J=2.5 \mathrm{~Hz}, 1 \mathrm{H})$, $6.26(\mathrm{~d}, J=2.5 \mathrm{~Hz}, 1 \mathrm{H}), 5.67(\mathrm{q}, J=3.4 \mathrm{~Hz}, 1 \mathrm{H}), 4.09(\mathrm{dd}, J=12.7,3.4$ $\mathrm{Hz}, 1 \mathrm{H}), 3.79(\mathrm{~s}, 3 \mathrm{H}), 3.76(\mathrm{~s}, 3 \mathrm{H}), 3.09-3.04(\mathrm{~m}, 1 \mathrm{H}), 2.98(\mathrm{t}, J=$ $12.8 \mathrm{~Hz}, 1 \mathrm{H}), 2.79(\mathrm{dq}, J=12.9,3.1 \mathrm{~Hz}, 1 \mathrm{H}), 2.37(\mathrm{~s}, 3 \mathrm{H}), 2.23-2.21$ (m, 2H), 1.41-1.30 (m, 1H), $0.94(\mathrm{~s}, 3 \mathrm{H}) ;{ }^{13} \mathrm{C}\left\{{ }^{1} \mathrm{H}\right\}$ NMR $(75 \mathrm{MHz}$, $\left.\mathrm{CDCl}_{3}\right) \delta 159.4,158.2,143.7,141.6,137.9,137.5,136.6,129.6,128.3$, $127.9,127.5,127.3,126.9,120.3,100.5,96.5,55.5,45.7,43.4,36.2$, $31.7,23.9,21.7,17.3$; IR (neat) $\nu_{\max } 2935,2837,1604,1579,1418$, $1349,1201,1163,1152,664 \mathrm{~cm}^{-1}$; HRMS (ESI) $\mathrm{m} / z:[\mathrm{M}+\mathrm{Na}]^{+}$calcd for $\mathrm{C}_{29} \mathrm{H}_{31} \mathrm{NO}_{4} \mathrm{SNa} 512.1866$; found: 512.1860.

$(6 a S *, 10 a S *)-7-B r o m o-1,3-d i m e t h o x y-10 a-m e t h y l-5$-tosyl5,6,6a,9,10,10a-hexahydrophenanthridine [trans-4d]. ${ }^{14 c}$ According to the general procedure, the reaction of 1,5-enyne $(E)-3 d$ $(79.8 \mathrm{mg}, 0.17 \mathrm{mmol})$ with $\mathrm{InI}_{3}(4.1 \mathrm{mg}, 0.008 \mathrm{mg})$ afforded, after purification by column chromatography ( $5 \%$ EtOAc/hexanes), trans4d $(58.3 \mathrm{mg}, 73 \%)$ as a colorless oil; ${ }^{1} \mathrm{H}$ NMR $\left(300 \mathrm{MHz}, \mathrm{CDCl}_{3}\right) \delta$ 7.60-7.57 (m, 2H), 7.24-7.21 (m, 2H), $7.20(\mathrm{~d}, J=2.5 \mathrm{~Hz}, 1 \mathrm{H}), 6.25$ $(\mathrm{d}, J=2.5 \mathrm{~Hz}, 1 \mathrm{H}), 6.08(\mathrm{dd}, J=4.8,2.8 \mathrm{~Hz}, 1 \mathrm{H}), 4.65(\mathrm{dd}, J=13.0,3.5$ $\mathrm{Hz}, 1 \mathrm{H}), 3.81(\mathrm{~s}, 3 \mathrm{H}), 3.73(\mathrm{~s}, 3 \mathrm{H}), 3.24(\mathrm{t}, J=12.8 \mathrm{~Hz}, 1 \mathrm{H}), 3.00(\mathrm{dd}, J$ $=13.3,6.0 \mathrm{~Hz}, 1 \mathrm{H}), 2.41(\mathrm{~m}, 1 \mathrm{H}), 2.38(\mathrm{~s}, 3 \mathrm{H}), 2.14-2.05(\mathrm{~m}, 2 \mathrm{H})$, $1.20-1.12(\mathrm{~m}, 1 \mathrm{H}), 0.93(\mathrm{~s}, 3 \mathrm{H}) ;{ }^{13} \mathrm{C}\left\{{ }^{1} \mathrm{H}\right\} \operatorname{NMR}\left(75 \mathrm{MHz}, \mathrm{CDCl}_{3}\right) \delta$ $159.2,158.5,143.9,137.9,136.3,130.8,129.8,127.5,121.0,119.1$, $100.8,96.8,55.5,55.4,47.2,46.3,38.2,31.4,25.9,21.7,17.3$; HRMS (ESI) $m / z:[\mathrm{M}+\mathrm{H}]^{+}$calcd for $\mathrm{C}_{23} \mathrm{H}_{27} \mathrm{BrNO}_{4} \mathrm{~S}$ 492.0838; found 492.0839 .

$(6 \mathrm{a} R *, 10 \mathrm{a} S *)-10 \mathrm{a}-M e t h y l-5-$ tosyl-5,6,6a,9,10,10a-hexahydrophenanthridine [cis-4e]. According to the general procedure, reactions of 1,5-enyne $(E)-3 \mathrm{e}(85.5 \mathrm{mg}, 0.24 \mathrm{mmol})$ with $\mathrm{InI}_{3}(5.9 \mathrm{mg}$, $0.012 \mathrm{mmol})$ or 1,5 -enyne $(Z)-3 \mathrm{e}(89.0 \mathrm{mg}, 0.25)$ with $\operatorname{InI}_{3}(6.3 \mathrm{mg}$, $0.013 \mathrm{mmol}$ ) afforded, after purification by column chromatography 
(5\% EtOAc/hexanes), cis-4e [41.9 mg, 49\% from (E)-3e and $56.1 \mathrm{mg}$, $63 \%$ from $(Z)-3 \mathbf{e}]$ as a colorless oil; ${ }^{1} \mathrm{H}$ NMR $\left(300 \mathrm{MHz}, \mathrm{CDCl}_{3}\right) \delta$ 7.75-7.72 (m, 1H), 7.51-7.48 (m, 2H), 7.26-7.13 (m, 5H), 5.75 (ddd, $J=9.4,4.7,2.4 \mathrm{~Hz}, 1 \mathrm{H}), 5.45(\mathrm{ddt}, J=9.2,4.9,2.3 \mathrm{~Hz}, 1 \mathrm{H}), 4.16$ (dd, $J=14.1,3.4 \mathrm{~Hz}, 1 \mathrm{H}), 3.23(\mathrm{ddd}, J=15.2,10.8,4.4 \mathrm{~Hz}, 1 \mathrm{H}), 2.37(\mathrm{~s}$, $3 \mathrm{H}), 1.99-1.93(\mathrm{~m}, 2 \mathrm{H}), 1.81(\mathrm{~d}, J=11.3 \mathrm{~Hz}, 1 \mathrm{H}), 1.57(\mathrm{dt}, J=9.4,2.3$ $\mathrm{Hz}, 2 \mathrm{H}), 0.91(\mathrm{~s}, 3 \mathrm{H}) ;{ }^{13} \mathrm{C}\left\{{ }^{1} \mathrm{H}\right\} \mathrm{NMR}\left(126 \mathrm{MHz}, \mathrm{CDCl}_{3}\right) \delta$ 143.7, $139.0,137.4,135.7,129.7,128.9,127.6,127.3,126.4,125.7,125.5$, 124.5, 48.4, 39.3, 34.7, 33.3, 25.7, 22.4, 21.6; IR (neat) $\nu_{\max } 2925$, 1486, $1447,1347,1163,1090,658 \mathrm{~cm}^{-1}$; HRMS (ESI) $\mathrm{m} / z:[\mathrm{M}+\mathrm{Na}]^{+}$calcd for $\mathrm{C}_{21} \mathrm{H}_{23} \mathrm{NO}_{2} \mathrm{SNa}$ : 376.1341; found: 376.1348 .

(6a $R *, 10$ a $\left.S^{*}\right)$-1,3-Dimethoxy-10a-methyl-5-tosyl5,6,6a,9,10,10a-hexahydrophenanthridine [cis-4a]. According to the general procedure, the reaction of 1,5 -enyne $(Z)-3 \mathrm{a}(95.3 \mathrm{mg}$, $0.23 \mathrm{mmol}$ ) with $\mathrm{InI}_{3}(5.7 \mathrm{mg}, 0.011 \mathrm{mmol})$ afforded, after purification by column chromatography (5\% EtOAc/hexanes), cis-4a ( $83.9 \mathrm{mg}$, $88 \%)$ as a white solid; $\mathrm{mp} 101-103{ }^{\circ} \mathrm{C}$; ${ }^{1} \mathrm{H} \mathrm{NMR}\left(300 \mathrm{MHz}, \mathrm{CDCl}_{3}\right) \delta$ $7.52(\mathrm{~d}, J=8.1 \mathrm{~Hz}, 2 \mathrm{H}), 7.20(\mathrm{~d}, J=8.1 \mathrm{~Hz}, 2 \mathrm{H}), 6.97(\mathrm{~d}, J=2.6 \mathrm{~Hz}$, $1 \mathrm{H}), 6.31(\mathrm{~d}, J=2.6 \mathrm{~Hz}, 1 \mathrm{H}), 5.79-5.75(\mathrm{~m}, 1 \mathrm{H}), 5.41-5.38(\mathrm{~m}, 1 \mathrm{H})$, $4.14(\mathrm{dd}, J=14.0,3.2 \mathrm{~Hz}, 1 \mathrm{H}), 3.79(\mathrm{~s}, 3 \mathrm{H}), 3.75(\mathrm{~s}, 3 \mathrm{H}), 3.17(\mathrm{dd}, J=$ 14.0, 11.2 Hz, 1H), $2.37(\mathrm{~s}, 3 \mathrm{H}), 2.15(\mathrm{dt}, J=13.2,4.2 \mathrm{~Hz}, 1 \mathrm{H}), 1.93-$ $1.87(\mathrm{~m}, 2 \mathrm{H}), 1.74(\mathrm{~d}, J=11.0 \mathrm{~Hz}, 1 \mathrm{H}), 1.42(\mathrm{ddd}, J=13.1,10.6,5.4$ $\mathrm{Hz}, 1 \mathrm{H}), 0.95(\mathrm{~s}, 3 \mathrm{H}) ;{ }^{13} \mathrm{C}\left\{{ }^{1} \mathrm{H}\right\}$ NMR $\left(75 \mathrm{MHz}, \mathrm{CDCl}_{3}\right) \delta 159.9$, 158.0, 143.7, 137.9, 137.6, 129.7, 129.5, 127.3, 125.6, 120.2, 101.2, 97.8, $55.5,55.3,48.3,41.5,34.9,28.0,22.6,22.3,21.6$; IR (neat) $\nu_{\max } 2928$, $2837,1607,1579,1460,1349,1161,672 \mathrm{~cm}^{-1}$; HRMS (ESI) $\mathrm{m} / z$ : [M $+\mathrm{Na}]^{+}$calcd for $\mathrm{C}_{23} \mathrm{H}_{27} \mathrm{NO}_{4} \mathrm{SNa} 436.1553$; found 436.1555 .

$(6 \mathrm{a} R *, 10 \mathrm{a} S *)-7-$ Bromo-1,3-dimethoxy-10a-methyl-5-tosyl5,6,6a,9,10,10a-hexahydrophenanthridine [cis-4d]. According to the general procedure, the reaction of 1,5 -enyne $(Z)-3 \mathrm{~d}(90.2 \mathrm{mg}$, $0.18 \mathrm{mmol}$ ) with $\mathrm{InI}_{3}(4.6 \mathrm{mg}, 0.009 \mathrm{mmol})$ afforded, after purification by column chromatography ( $5 \% \mathrm{EtOAc} /$ hexanes), cis-4d $(64.9 \mathrm{mg}$, $72 \%)$ as a white solid; mp $144-146{ }^{\circ} \mathrm{C} ;{ }^{1} \mathrm{H} \mathrm{NMR}\left(300 \mathrm{MHz}, \mathrm{CDCl}_{3}\right) \delta$ $7.53(\mathrm{~d}, J=8.3 \mathrm{~Hz}, 2 \mathrm{H}), 7.23(\mathrm{~d}, J=8.3 \mathrm{~Hz}, 2 \mathrm{H}), 7.12(\mathrm{~d}, J=2.6 \mathrm{~Hz}$, $1 \mathrm{H}), 6.34(\mathrm{~d}, J=2.6 \mathrm{~Hz}, 1 \mathrm{H}), 6.12(\mathrm{t}, J=4.0 \mathrm{~Hz}, 1 \mathrm{H}), 4.65(\mathrm{dd}, J=14.3$, $3.2 \mathrm{~Hz}, 1 \mathrm{H}), 3.84(\mathrm{~s}, 3 \mathrm{H}), 3.75(\mathrm{~s}, 3 \mathrm{H}), 3.06(\mathrm{dd}, J=14.3,11.9 \mathrm{~Hz}, 1 \mathrm{H})$, $2.37(\mathrm{~s}, 3 \mathrm{H}), 2.30-2.24(\mathrm{~m}, 1 \mathrm{H}), 1.99-1.95(\mathrm{~m}, 2 \mathrm{H}), 1.79-1.75(\mathrm{~m}$, $1 \mathrm{H}), 1.25$ (ddd, $J=13.6,10.6,6.7 \mathrm{~Hz}, 1 \mathrm{H}), 0.92(\mathrm{~s}, 3 \mathrm{H}) ;{ }^{13} \mathrm{C}\left\{{ }^{1} \mathrm{H}\right\}$ NMR $\left(75 \mathrm{MHz}, \mathrm{CDCl}_{3}\right) \delta 159.4,158.3,143.9,137.8,136.8,131.1$, $129.7,127.7,121.5,120.1,102.1,98.3,55.6,55.3,49.0,47.4,37.3,26.1$, 24.7, 21.7, 21.4; IR (neat) $\nu_{\max } 2932,1608,1579,1461,1352,1203$, $1164,672 \mathrm{~cm}^{-1}$; HRMS (ESI) $m / z:[\mathrm{M}+\mathrm{Na}]^{+}$calcd for $\mathrm{C}_{23} \mathrm{H}_{26} \mathrm{BrNO}_{4} \mathrm{SNa} 514.0658$; found: 514.0657.

$\left(6 a S^{*}, 10 a S^{*}\right)-1,3-D i m e t h o x y-5$-tosyl-5,6,6a,9, 10,10a-hexahydrophenanthridine [trans-4f]. According to the general procedure, the reaction of 1,5 -enyne $(E)-3 \mathrm{f}(85.0 \mathrm{mg}, 0.22 \mathrm{mmol})$ with $\mathrm{InI}_{3}(5.5 \mathrm{mg}, 0.011 \mathrm{mmol})$ afforded, after purification by column chromatography (5\% EtOAc/hexanes), trans- $4 \mathrm{f}(67.2 \mathrm{mg}, 79 \%$, ) as a white solid; mp $101-103{ }^{\circ} \mathrm{C} ;{ }^{1} \mathrm{H} \mathrm{NMR}\left(500 \mathrm{MHz}, \mathrm{CDCl}_{3}\right) \delta 7.55(\mathrm{~d}, J$ $=8.3 \mathrm{~Hz}, 2 \mathrm{H}), 7.21(\mathrm{~d}, J=8.3 \mathrm{~Hz}, 2 \mathrm{H}), 7.07(\mathrm{~d}, J=2.5 \mathrm{~Hz}, 1 \mathrm{H}), 6.26(\mathrm{~d}$, $J=2.5 \mathrm{~Hz}, 1 \mathrm{H}), 5.66-5.63(\mathrm{~m}, 1 \mathrm{H}), 5.52(\mathrm{dq}, J=9.7,2.0 \mathrm{~Hz}, 1 \mathrm{H}), 4.22$ (dd, $J=12.8,3.7 \mathrm{~Hz}, 1 \mathrm{H}), 3.80(\mathrm{~s}, 3 \mathrm{H}), 3.73(\mathrm{~s}, 3 \mathrm{H}), 3.05(\mathrm{dd}, J=12.8$, $12.1 \mathrm{~Hz}, 1 \mathrm{H}), 2.82(\mathrm{ddt}, J=13.0,5.5,2.5 \mathrm{~Hz}, 1 \mathrm{H}), 2.38(\mathrm{~s}, 3 \mathrm{H}), 2.21$ $(\mathrm{td}, J=11.2,11.2,2.2 \mathrm{~Hz}, 1 \mathrm{H}), 2.19-1.99(\mathrm{~m}, 2 \mathrm{H}), 2.02(\mathrm{bt}, J=11.5$ $\mathrm{Hz}, 1 \mathrm{H}), 1.03-0.96(\mathrm{~m}, 1 \mathrm{H}) ;{ }^{13} \mathrm{C}\left\{{ }^{1} \mathrm{H}\right\} \operatorname{NMR}\left(126 \mathrm{MHz} \mathrm{CDCl}_{3}\right) \delta$ $159.6,158.5,143.7,139.1,137.0,129.7,128.8,127.7,127.3,114.8$, $101.3,96.6,55.6,55.4,51.2,39.2,38.6,27.2,27.1,21.7$; IR (neat) $\nu_{\max }$ 2929, 2836, 1607, 1579, 1455, 1346, 1185, 1162, $665 \mathrm{~cm}^{-1}$; HRMS (ESI) $m / z:[\mathrm{M}+\mathrm{Na}]^{+}$calcd for $\mathrm{C}_{22} \mathrm{H}_{25} \mathrm{NO}_{4} \mathrm{SNa}$ 422.1396; found 422.1397.

(4S*,9S*)-7-Methoxy-4-methyl-4,9-tetrahydro-3H-xanthene [trans-6a]. ${ }^{20}$ According to the general procedure, the reaction of $1,5-$ enyne $(E)-5 \mathrm{a}^{20}(97.6 \mathrm{mg}, 0.42 \mathrm{mmol})$ with $\operatorname{InI}_{3}(10.5 \mathrm{mg}, 0.021 \mathrm{mmol})$ afforded, after purification by column chromatography (5\% EtOAc/ hexanes), trans-6a (83.9 mg, 86\%) as a white solid; ${ }^{1} \mathrm{H}$ NMR (400 $\left.\mathrm{MHz}, \mathrm{CDCl}_{3}\right) \delta 6.76(\mathrm{~d}, J=8.8 \mathrm{~Hz}, 1 \mathrm{H}), 6.70(\mathrm{dd}, J=8.9,2.9 \mathrm{~Hz}, 1 \mathrm{H})$, $6.63(\mathrm{~d}, J=2.9 \mathrm{~Hz}, 1 \mathrm{H}), 5.68-5.65(\mathrm{~m}, 1 \mathrm{H}), 5.49(\mathrm{ddt}, J=9.7,2.9,1.6$ $\mathrm{Hz}, 1 \mathrm{H}), 3.76(\mathrm{~s}, 3 \mathrm{H}), 2.69(\mathrm{dd}, J=13.9,3.4 \mathrm{~Hz}, 1 \mathrm{H}), 2.67-2.47(\mathrm{~m}$, $2 \mathrm{H}), 2.34-2.29(\mathrm{~m}, 1 \mathrm{H}), 2.26-2.22(\mathrm{~m}, 1 \mathrm{H}), 1.98-1.93(\mathrm{~m}, 1 \mathrm{H}), 1.86$ $(\mathrm{td}, J=11.9,6.9 \mathrm{~Hz}, 1 \mathrm{H}), 1.10(\mathrm{~s}, 3 \mathrm{H}) ;{ }^{13} \mathrm{C}\left\{{ }^{1} \mathrm{H}\right\} \operatorname{NMR}(75 \mathrm{MHz}$,
$\left.\mathrm{CDCl}_{3}\right) \delta 153.1,148.0,128.5,127.0,123.1,118.1,114.5,113.7,75.5$ 55.8, 39.1, 35.4, 28.5, 25.2, 16.0; HRMS (EI) $\mathrm{m} / z$ : $[\mathrm{M}]^{+}$calcd for $\mathrm{C}_{15} \mathrm{H}_{18} \mathrm{O}_{2}[\mathrm{M}]^{+}: 230.1301$; found: 230.1294 .

$\left(4 S^{*}, 9 R^{*}\right)-1$-Bromo-7-methoxy-4-methyl-4,9-tetrahydro-3Hxanthene [trans-6b]. ${ }^{14 c}$ According to the general procedure, the reaction of 1,5-enyne $(E)-5 \mathbf{b}^{14 c}(105.4 \mathrm{mg}, 0.31 \mathrm{mmol})$ with $\mathrm{InI}_{3}(7.7$ $\mathrm{mg}, 0.016 \mathrm{mmol}$ ) afforded, after purification by column chromatography (5\% EtOAc/hexanes), trans-6b $(93.8 \mathrm{mg}, 89 \%)$ as a white solid; ${ }^{1} \mathrm{H}$ NMR $\left(300 \mathrm{MHz}, \mathrm{CDCl}_{3}\right) \delta 6.78-6.67(\mathrm{~m}, 3 \mathrm{H}), 6.11-6.08(\mathrm{~m}$, $1 \mathrm{H}), 3.76(\mathrm{~s}, 3 \mathrm{H}), 3.05(\mathrm{dd}, J=16.1,5.2 \mathrm{~Hz}, 1 \mathrm{H}), 2.86-2.82(\mathrm{~m}, 1 \mathrm{H})$, $2.57(\mathrm{ddt}, J=16.1,13.4,1.0 \mathrm{~Hz}, 1 \mathrm{H}), 2.29-2.24(\mathrm{~m}, 2 \mathrm{H}), 1.99-1.89$ $(\mathrm{m}, 2 \mathrm{H}), 1.15(\mathrm{~s}, 3 \mathrm{H}) ;{ }^{13} \mathrm{C}\left\{{ }^{1} \mathrm{H}\right\}$ NMR $\left(75 \mathrm{MHz}, \mathrm{CDCl}_{3}\right) \delta$ 153.4, 147.2 , 129.2, 123.8, 122.6, 117.9, 114.3, 114.1, 76.1, 55.8, 45.1, 34.9, 29.0, 25.9, 16.5; HRMS (ESI) $m / z:[\mathrm{M}+\mathrm{H}]^{+}$calcd for $\mathrm{C}_{15} \mathrm{H}_{18} \mathrm{BrO}_{2}$ 309.0484; found: 309.0481 .

$\left(4 S^{*}, 9 R^{*}\right)$-7-Methoxy-4-methyl-4,9-tetrahydro-3H-xanthene [cis-6a]. According to the general procedure, the reaction of 1,5-enyne (Z)-5a ( $82.7 \mathrm{mg}, 0.35 \mathrm{mmol})$ with $\mathrm{InI}_{3}(8.9 \mathrm{mg}, 0.017 \mathrm{mmol})$ afforded, after purification by column chromatography ( $5 \% \mathrm{EtOAc} /$ hexanes), cis6a $(71.9 \mathrm{mg}, 87 \%)$ as a white solid; $\mathrm{mp} 75-77^{\circ} \mathrm{C}$; ${ }^{1} \mathrm{H}$ NMR $(300 \mathrm{MHz}$, $\left.\mathrm{CDCl}_{3}\right) \delta 6.69-6.67(\mathrm{~m}, 2 \mathrm{H}), 6.58(\mathrm{~d}, J=2.6 \mathrm{~Hz}, 1 \mathrm{H}), 5.72-5.68(\mathrm{~m}$, $1 \mathrm{H}), 5.35(\mathrm{dq}, J=9.9,2.2 \mathrm{~Hz}, 1 \mathrm{H}), 3.74(\mathrm{~s}, 3 \mathrm{H}), 3.08(\mathrm{dd}, J=16.3,6.1$ $\mathrm{Hz}, 1 \mathrm{H}), 2.52(\mathrm{dd}, J=16.3,3.7 \mathrm{~Hz}, 1 \mathrm{H}), 2.43(\mathrm{dt}, J=5.6,2.8 \mathrm{~Hz}, 1 \mathrm{H})$, $2.31(\mathrm{ddq}, J=15.7,9.5,2.9 \mathrm{~Hz}, 1 \mathrm{H}), 2.06-1.95(\mathrm{~m}, 2 \mathrm{H}), 1.70$ (ddd, $J=$ $13.4,9.6,6.6 \mathrm{~Hz}, 1 \mathrm{H}), 1.33(\mathrm{~s}, 3 \mathrm{H}) ;{ }^{13} \mathrm{C}\left\{{ }^{1} \mathrm{H}\right\} \mathrm{NMR}\left(75 \mathrm{MHz} \mathrm{CDCl}_{3}\right) \delta$ 152.9, 148.1, 128.8, 128.5, 120.0, 117.2, 114.1, 113.5, 73.7, 55.8, 36.8, 33.8, 29.7, 26.0, 22.9; IR (neat) $\nu_{\max } 2921,2832,1494,1236,1213$, 1101, $1041 \mathrm{~cm}^{-1}$; HRMS (EI) $\mathrm{m} / z$ : $[\mathrm{M}]^{+}$calcd for $\mathrm{C}_{15} \mathrm{H}_{18} \mathrm{O}_{2}$ 230.1301; found 230.1293.

$\left(4 S^{*}, 9 S^{*}\right)-1-$ Bromo-7-methoxy-4-methyl-4,9-tetrahydro-3Hxanthene [cis-6b]. According to the general procedure, the reaction of 1,5-enyne $(Z)-5 \mathbf{b}(76.0 \mathrm{mg}, 0.25 \mathrm{mmol})$ with $\mathrm{InI}_{3}(6.1 \mathrm{mg}, 0.012$ $\mathrm{mmol}$ ) afforded, after purification by column chromatography (5\% EtOAc/hexanes), cis-6b (69.9 mg, 92\%) as a white solid; ${ }^{1} \mathrm{H}$ NMR (300 $\left.\mathrm{MHz}, \mathrm{CDCl}_{3}\right) \delta 6.70-6.69(\mathrm{~m}, 2 \mathrm{H}), 6.61(\mathrm{~d}, J=2.6 \mathrm{~Hz}, 1 \mathrm{H}), 6.05(\mathrm{td}, J$ $=4.1,1.6 \mathrm{~Hz}, 1 \mathrm{H}), 3.76(\mathrm{~s}, 3 \mathrm{H}), 3.13(\mathrm{dd}, J=16.6,6.0 \mathrm{~Hz}, 1 \mathrm{H}), 2.94$ $(\mathrm{dd}, J=16.6,6.0 \mathrm{~Hz}, 1 \mathrm{H}), 2.62(\mathrm{~m}, 1 \mathrm{H}), 2.36-2.30(\mathrm{~m}, 1 \mathrm{H}), 2.11-$ $2.02(\mathrm{~m}, 1 \mathrm{H}), 1.94(\mathrm{dt}, J=12.4,6.1 \mathrm{~Hz}, 1 \mathrm{H}), 1.74-1.65(\mathrm{~m}, 1 \mathrm{H}), 1.42$ $(\mathrm{s}, 3 \mathrm{H}) ;{ }^{13} \mathrm{C}\left\{{ }^{1} \mathrm{H}\right\}$ NMR $\left(126 \mathrm{MHz}, \mathrm{CDCl}_{3}\right) \delta 153.3,147.6,129.9$, 124.4, 120.2, 117.1, 113.8, 113.7, 75.9, 55.9, 45.5, 31.6, 29.1, 26.4, 25.0; HRMS (EI) $m / z$ : $[\mathrm{M}]^{+}$calcd for $\mathrm{C}_{15} \mathrm{H}_{17} \mathrm{BrO}_{2}$ 308.0406; found: 308.0395 .

$5^{\prime}, 7^{\prime}$-Dimethoxyspiro[cyclohexane-1,4'-isochroman]-3-ene (8a). ${ }^{14 c}$ According to the general procedure, the reaction of 1,5 -enyne $7 \mathrm{a}(98.3 \mathrm{mg}, 0.38 \mathrm{mmol})$ with $\operatorname{InI}_{3}(9.5 \mathrm{mg}, 0.019 \mathrm{mmol})$ afforded, after purification by column chromatography ( $5 \% \mathrm{EtOAc/hexanes),} \mathrm{8 \mathbf {a }}$ $(82.6 \mathrm{mg}, 84 \%)$ as a colorless oil; ${ }^{1} \mathrm{H}$ NMR $\left(300 \mathrm{MHz}, \mathrm{CDCl}_{3}\right) \delta 6.35$ $(\mathrm{d}, J=2.5 \mathrm{~Hz}, 1 \mathrm{H}), 6.12(\mathrm{~d}, J=2.5 \mathrm{~Hz}, 1 \mathrm{H}), 5.70(\mathrm{~d}, J=2.6 \mathrm{~Hz}, 2 \mathrm{H})$, $4.69(\mathrm{~d}, J=0.8 \mathrm{~Hz}, 2 \mathrm{H}), 3.92(\mathrm{~d}, J=11.4 \mathrm{~Hz}, 1 \mathrm{H}), 3.79(\mathrm{~s}, 3 \mathrm{H}), 3.78(\mathrm{~s}$, $3 \mathrm{H}), 3.59(\mathrm{dd}, J=11.4,1.3 \mathrm{~Hz}, 1 \mathrm{H}), 2.88-2.68(\mathrm{~m}, 2 \mathrm{H}), 2.08-2.01$ $(\mathrm{m}, 3 \mathrm{H}), 1.46-1.42(\mathrm{~m}, 1 \mathrm{H}) ;{ }^{13} \mathrm{C}\left\{{ }^{1} \mathrm{H}\right\} \operatorname{NMR}\left(75 \mathrm{MHz}, \mathrm{CDCl}_{3}\right) \delta$ 159.8, 158.6, 137.5, 126.4, 125.5, 122.5, 99.9, 98.1, 73.9, 70.0, 55.3, 55.1, 34.5, 31.6, 27.5, 22.1; HRMS (ESI) $\mathrm{m} / z:[\mathrm{M}+\mathrm{H}]^{+}$calcd for $\mathrm{C}_{16} \mathrm{H}_{21} \mathrm{O}_{3}$ 261.1485; found: 261.1479 .

$5^{\prime}, 7^{\prime}$-Dimethoxy-2'-tosyl-2', 3'-dihydro-1' $\mathrm{H}$-spiro[cyclohexane-1,4'-isoquinolin]-3-ene (8b). ${ }^{14 c}$ According to the general procedure, the reaction of 1,5 -enyne $7 \mathbf{b}(88.5 \mathrm{mg}, 0.21 \mathrm{mmol})$ with $\mathrm{InI}_{3}(5.3 \mathrm{mg}, 0.011 \mathrm{mmol})$ afforded, after purification by column chromatography (10\% EtOAc/hexanes), $\mathbf{8 b}(81.4,92 \%)$ as a colorless oil; ${ }^{1} \mathrm{H}$ NMR $\left(300 \mathrm{MHz}, \mathrm{CDCl}_{3}\right) \delta 7.72(\mathrm{~d}, J=8.0 \mathrm{~Hz}, 2 \mathrm{H}), 7.34(\mathrm{~d}, J=$ $8.0 \mathrm{~Hz}, 2 \mathrm{H}), 6.32(\mathrm{~d}, J=2.5 \mathrm{~Hz}, 1 \mathrm{H}), 6.15(\mathrm{~d}, J=2.5 \mathrm{~Hz}, 1 \mathrm{H}), 5.76-$ $5.65(\mathrm{~m}, 2 \mathrm{H}), 4.16(\mathrm{~d}, J=14.5 \mathrm{~Hz}, 1 \mathrm{H}), 4.00(\mathrm{~d}, J=14.5 \mathrm{~Hz}, 1 \mathrm{H}), 3.76$ $(\mathrm{s}, 3 \mathrm{H}), 3.75(\mathrm{~s}, 3 \mathrm{H}), 3.16(\mathrm{~d}, J=11.7 \mathrm{~Hz}, 1 \mathrm{H}), 3.00-2.93(\mathrm{~m}, 2 \mathrm{H})$, $2.69(\mathrm{td}, J=13.1,12.4,6.8 \mathrm{~Hz}, 1 \mathrm{H}), 2.44(\mathrm{~s}, 3 \mathrm{H}), 2.12(\mathrm{~m}, 2 \mathrm{H}), 1.90(\mathrm{~d}$, $J=18.2 \mathrm{~Hz}, 1 \mathrm{H}), 1.45(\mathrm{dd}, J=13.5,5.5 \mathrm{~Hz}, 1 \mathrm{H}) ;{ }^{13} \mathrm{C}\left\{{ }^{1} \mathrm{H}\right\} \operatorname{NMR}(126$ $\left.\mathrm{MHz} \mathrm{CDCl}_{3}\right) \delta 159.8,158.7,143.7,134.4,133.0,129.8,128.0,126.0$, 125.5, 122.9, 102.1, 98.5, 55.4, 55.2, 52.5, 50.1, 37.0, 31.9, 27.8, 22.0, 21.7; HRMS (EI) $\mathrm{m} / z$ : $[\mathrm{M}]^{+}$calcd for $\mathrm{C}_{23} \mathrm{H}_{27} \mathrm{NO}_{4} \mathrm{~S} 413.1655$; found 413.1643. 
3-Bromo-5', $7^{\prime}$-dimethoxy-2'-tosyl-2', 3'-dihydro-1' $H$-spiro[cyclohexane-1,4'-isoquinolin]-3-ene (8c). ${ }^{14 c}$ According to the general procedure, the reaction of 1,5 -enyne $7 \mathrm{c}(95.0 \mathrm{mg}, 0.19 \mathrm{mmol})$ with $\mathrm{InI}_{3}(4.8 \mathrm{mg}, 0.010 \mathrm{mmol})$ afforded, after purification by column chromatography (10\% EtOAc/hexanes), 8c $(72.2 \mathrm{mg}, 76 \%)$ as a colorless oil; ${ }^{1} \mathrm{H}$ NMR $\left(300 \mathrm{MHz}, \mathrm{CDCl}_{3}\right) \delta 7.73(\mathrm{~d}, J=8.1 \mathrm{~Hz}, 2 \mathrm{H})$, 7.35 (d, $J=8.1 \mathrm{~Hz}, 2 \mathrm{H}), 6.35(\mathrm{~d}, J=2.5 \mathrm{~Hz}, 1 \mathrm{H}), 6.15(\mathrm{~d}, J=2.5 \mathrm{~Hz}$ $1 \mathrm{H}), 6.08(\mathrm{~m}, 1 \mathrm{H}), 4.10(\mathrm{q}, J=14.6 \mathrm{~Hz}, 2 \mathrm{H}), 3.78(\mathrm{~s}, 3 \mathrm{H}), 3.74(\mathrm{~s}, 3 \mathrm{H})$, $3.51-3.44(\mathrm{~m}, 1 \mathrm{H}), 3.19(\mathrm{~d}, J=12.0 \mathrm{~Hz}, 1 \mathrm{H}), 2.95(\mathrm{~d}, J=11.9 \mathrm{~Hz}, 1 \mathrm{H})$, $2.55(\mathrm{td}, J=12.3,6.5 \mathrm{~Hz}, 1 \mathrm{H}), 2.44(\mathrm{~s}, 3 \mathrm{H}), 2.26-2.09(\mathrm{~m}, 3 \mathrm{H}), 1.64-$ $1.53(\mathrm{~m}, 1 \mathrm{H}) ;{ }^{13} \mathrm{C}\left\{{ }^{1} \mathrm{H}\right\} \mathrm{NMR}\left(75 \mathrm{MHz}, \mathrm{CDCl}_{3}\right) \delta 159.4,159.0,143.8$, 134.4, 132.9, 129.8, 127.8, 127.0, 121.0, 120.8, 102.2, 98.4, 55.3, 55.2, $52.2,49.8,41.3,39.6,26.3,24.0,21.6$; HRMS (EI) $m / z:[\mathrm{M}]^{+}$calcd for $\mathrm{C}_{23} \mathrm{H}_{26} \mathrm{BrNO}_{4} \mathrm{~S}: 491.0760$; found 491.0770 .

General Procedure for the One-Pot Sequential IndiumCatalyzed Cycloisomerization and Palladium-Catalyzed CrossCoupling Reactions of $(E)-5 b$ and 7c. In a Schlenk tube filled with argon, $\mathrm{InI}_{3}(5 \mathrm{~mol} \%)$ was placed and a solution of 1,5-enyne (E)-5b or $7 \mathbf{c}(\sim 0.07 \mathrm{M})$ in toluene was stirred at room temperature (for $\mathbf{5 b})$ or $60^{\circ} \mathrm{C}$ in an oil bath (for 7c) until the starting material was consumed (TLC). Then, $\mathrm{Pd}\left(\mathrm{PPh}_{3}\right)_{4}(5 \mathrm{~mol} \%)$ and a solution of $\mathrm{R}_{3} \mathrm{In}(70 \mathrm{~mol} \%$, $0.45 \mathrm{M}$ in dry THF) were added and the mixture was stirred at $80^{\circ} \mathrm{C}$ in an oil bath for $10 \mathrm{~h}$. The reaction was quenched by the addition of a few drops of $\mathrm{MeOH}$ and the mixture was concentrated in vacuo. $\mathrm{H}_{2} \mathrm{O}(10$ $\mathrm{mL})$ was added and the aqueous phase was extracted with EtOAc $(3 \times$ $10 \mathrm{~mL})$. The combined organic phase was washed with brine $(15 \mathrm{~mL})$, dried with anhydrous $\mathrm{MgSO}_{4}$, filtered, and concentrated in vacuo. The residue was purified by flash chromatography to afford, after concentration and high vacuo drying, the corresponding products trans-6c-e and $8 \mathrm{~d}$.

(4S*,9S*)-7-Methoxy-4-methyl-1-phenyl-4,9-tetrahydro-3Hxanthene [trans-6c]. ${ }^{20}$ According to the general procedure, the reaction of 1,5-enyne $(E)-5 \mathbf{b}^{14 \mathrm{c}}(96.0 \mathrm{mg}, 0.31 \mathrm{mmol})$ with $\operatorname{InI}_{3}(7.1$ $\mathrm{mg}, 0.016 \mathrm{mmol})$, triphenylindium $(0.217 \mathrm{mmol})$, and $\mathrm{Pd}\left(\mathrm{PPh}_{3}\right)_{4}$ $(17.5 \mathrm{mg}, 0.016 \mathrm{mmol})$ afforded, after purification by column chromatography (5\% EtOAc/hexanes), trans-6c $(72.2 \mathrm{mg}, 76 \%$ in two steps) as a white solid; ${ }^{1} \mathrm{H}$ NMR $\left(300 \mathrm{MHz}, \mathrm{CDCl}_{3}\right) \delta 7.36-7.28$ $(\mathrm{m}, 3 \mathrm{H}), 7.26-7.20(\mathrm{~m}, 2 \mathrm{H}), 6.78(\mathrm{~d}, J=8.9 \mathrm{~Hz}, 1 \mathrm{H}), 6.69(\mathrm{dd}, J=8.9$, $2.9 \mathrm{~Hz}, 1 \mathrm{H}), 6.51(\mathrm{~d}, J=3.0 \mathrm{~Hz}, 1 \mathrm{H}), 5.73(\mathrm{dt}, J=5.1,2.7 \mathrm{~Hz}, 1 \mathrm{H}), 3.70$ $(\mathrm{s}, 3 \mathrm{H}), 3.08-3.03(\mathrm{~m}, 1 \mathrm{H}), 2.70(\mathrm{dd}, J=16.7,5.2 \mathrm{~Hz}, 1 \mathrm{H}), 2.45-2.35$ (m, 2H), 2.27-2.16 (m, 1H), 2.03-1.99 (m, 2H), $1.19(\mathrm{~s}, 3 \mathrm{H})$; ${ }^{13} \mathrm{C}\left\{{ }^{1} \mathrm{H}\right\} \mathrm{NMR}\left(75 \mathrm{MHz}, \mathrm{CDCl}_{3}\right) \delta 153.1,147.5,141.4,140.0,128.2$, 127.5, 126.9, 126.1, 123.3, 118.0, 114.2, 114.0, 76.0, 55.8, 40.6, 35.3, 27.3, 24.7, 16.6; HRMS (EI) $\mathrm{m} / z$ : $[\mathrm{M}]^{+}$calcd for $\mathrm{C}_{21} \mathrm{H}_{22} \mathrm{O}_{2}$ 306.1614; found: 306.1587 .

$\left(4 S^{*}, 9 S^{*}\right)-7-M e t h o x y-1,4-d i m e t h y l-4,9-t e t r a h y d r o-3 H$-xanthene $[$ trans- $6 \mathrm{~d}] .{ }^{20}$ According to the general procedure, the reaction of 1,5-enyne $(E)-5 \mathbf{b}(96.3 \mathrm{mg}, 0.31 \mathrm{mmol})$ with $\mathrm{InI}_{3}(7.1 \mathrm{mg}, 0.016$ $\mathrm{mmol})$, trimethylindium $(0.217 \mathrm{mmol})$, and $\mathrm{Pd}\left(\mathrm{PPh}_{3}\right)_{4}(17.5 \mathrm{mg}$, $0.016 \mathrm{mmol}$ ) afforded, after purification by column chromatography (5\% EtOAc/hexanes), trans-6d (62.9 mg, $83 \%$ in two steps) as a white solid; ${ }^{1} \mathrm{H}$ NMR (300 MHz, $\left.\mathrm{CDCl}_{3}\right) \delta 6.77-6.65(\mathrm{~m}, 3 \mathrm{H}), 5.39(\mathrm{~m}$, $1 \mathrm{H}), 3.76(\mathrm{~s}, 3 \mathrm{H}), 2.87-2.79(\mathrm{~m}, 1 \mathrm{H}), 2.53-2.50(\mathrm{~m}, 2 \mathrm{H}), 2.21-2.18$ $(\mathrm{m}, 2 \mathrm{H}), 1.92-1.82(\mathrm{~m}, 2 \mathrm{H}), 1.72(\mathrm{~s}, 3 \mathrm{H}), 1.09(\mathrm{~s}, 3 \mathrm{H}) ;{ }^{13} \mathrm{C}\left\{{ }^{1} \mathrm{H}\right\}$ NMR $\left(75 \mathrm{MHz}, \mathrm{CDCl}_{3}\right) \delta 153.1,147.7,133.7,123.1,121.7,117.9$, $114.5,113.7,75.9,55.8,42.1,35.6,26.4,24.2,20.1,16.5$; HRMS (EI) $\mathrm{m} / z:[\mathrm{M}]^{+}$calcd for $\mathrm{C}_{16} \mathrm{H}_{20} \mathrm{O}_{2}$ 244.1458; found 244.1439.

$\left(4 S^{*}, 9 S^{*}\right)$-1-Butyl-7-methoxy-4-methyl-4,9-tetrahydro-3Hxanthene [trans-6e]. According to the general procedure, the reaction of 1,5-enyne $(E)-5 \mathbf{b}^{14 \mathrm{c}}(95.7 \mathrm{mg}, 0.31 \mathrm{mmol})$ with $\operatorname{InI}_{3}(7.1$ $\mathrm{mg}, 0.016 \mathrm{mmol})$, tributylindium $(0.217 \mathrm{mmol})$, and $\mathrm{Pd}\left(\mathrm{PPh}_{3}\right)_{4}(17.5$ $\mathrm{mg}, 0.016 \mathrm{mmol}$ ) afforded, after purification by column chromatography (5\% EtOAc/hexanes), trans-6e (71.9 $\mathrm{mg}, 81 \%$ two steps) as a white solid; mp $48-50{ }^{\circ} \mathrm{C}$; ${ }^{1} \mathrm{H}$ NMR $\left(300 \mathrm{MHz}, \mathrm{CDCl}_{3}\right) \delta 6.78-6.72$ $(\mathrm{m}, 2 \mathrm{H}), 6.66(\mathrm{~d}, J=2.7 \mathrm{~Hz}, 1 \mathrm{H}), 5.39(\mathrm{~m}, 1 \mathrm{H}), 3.76(\mathrm{~s}, 3 \mathrm{H}), 2.85(\mathrm{~d}, J$ $=11.0 \mathrm{~Hz}, 1 \mathrm{H}), 2.54-2.50(\mathrm{~m}, 2 \mathrm{H}), 2.21(\mathrm{~m}, 2 \mathrm{H}), 2.06-1.81(\mathrm{~m}, 4 \mathrm{H})$, $1.41-1.26(\mathrm{~m}, 4 \mathrm{H}), 1.09(\mathrm{~s}, 3 \mathrm{H}), 0.92(\mathrm{t}, J=7.0 \mathrm{~Hz}, 3 \mathrm{H}) ;{ }^{13} \mathrm{C}\left\{{ }^{1} \mathrm{H}\right\}$ NMR $\left(75 \mathrm{MHz}, \mathrm{CDCl}_{3}\right) \delta 153.0,147.7,137.7,123.1,120.8,117.9$, $114.4,113.8,76.1,55.8,40.7,35.6,33.5,30.7,26.2,24.2,22.6,16.6$,
14.2; IR (neat) $\nu_{\max } 2929,2856,1493,1224,1148,1081,1041 \mathrm{~cm}^{-1}$; HRMS (EI) $m / z:[\mathrm{M}]^{+}$calcd for $\mathrm{C}_{19} \mathrm{H}_{26} \mathrm{O}_{2} 286.1927$; found: 286.1923 .

$5^{\prime}, 7^{\prime}$-Dimethoxy-3-phenyl-2' -tosyl-2', 3' -dihydro-1' $H$-spiro[cyclohexane-1,4'-isoquinolin]-3-ene (8d). According to the general procedure, the reaction of 1,5-enyne $7 \mathrm{c}(95.2 \mathrm{mg}, 0.19$ mmol) with $\mathrm{InI}_{3}(4.9 \mathrm{mg}, 0.010 \mathrm{mmol})$, triphenylindium $(0.13 \mathrm{mmol})$, and $\mathrm{Pd}\left(\mathrm{PPh}_{3}\right)_{4}(11.0 \mathrm{mg}, 0.010 \mathrm{mmol})$ afforded, after purification by column chromatography ( $5 \% \mathrm{EtOAc} /$ hexanes), $8 \mathrm{~d}$ ( $56.7 \mathrm{mg}, 61 \%$ in two steps) as a white solid; mp $125-127{ }^{\circ} \mathrm{C} ;{ }^{1} \mathrm{H}$ NMR $(300 \mathrm{MHz}$, $\left.\mathrm{CDCl}_{3}\right) \delta 7.70-7.67(\mathrm{~m}, 2 \mathrm{H}), 7.41-7.39(\mathrm{~m}, 2 \mathrm{H}), 7.32-7.21(\mathrm{~m}, 5 \mathrm{H})$, $6.35(\mathrm{~d}, J=2.5 \mathrm{~Hz}, 1 \mathrm{H}), 6.18(\mathrm{~d}, J=2.5 \mathrm{~Hz}, 1 \mathrm{H}), 6.13(\mathrm{q}, J=3.4,2.4 \mathrm{~Hz}$, $1 \mathrm{H}), 4.21-4.08(\mathrm{~m}, 2 \mathrm{H}), 3.76(\mathrm{~s}, 6 \mathrm{H}), 3.37(\mathrm{dd}, J=17.2,3.3 \mathrm{~Hz}, 1 \mathrm{H})$, $3.12(\mathrm{q}, J=11.9 \mathrm{~Hz}, 2 \mathrm{H}), 2.73-2.67(\mathrm{~m}, 1 \mathrm{H}), 2.39(\mathrm{~s}, 3 \mathrm{H}), 2.30(\mathrm{~d}, J=$ $17.3 \mathrm{~Hz}, 3 \mathrm{H}), 1.26(\mathrm{~m}, 1 \mathrm{H}) ;{ }^{13} \mathrm{C}\left\{{ }^{1} \mathrm{H}\right\}$ NMR $\left(126 \mathrm{MHz} \mathrm{CDCl}_{3}\right) \delta$ $159.8,158.9,143.7,142.6,135.7,134.6,133.2,129.8,128.3,127.9$, $126.8,125.5,123.0,122.6,102.2,98.6,55.4,55.3,52.5,50.0,37.7,34.0$, 27.2, 22.8, 21.7; IR (neat) $\nu_{\max } 2932,2841,1608,1460,1340,1164$, $1055,831 \mathrm{~cm}^{-1}$; HRMS (EI) $\mathrm{m} / z$ : $[\mathrm{M}]^{+}$calcd for $\mathrm{C}_{29} \mathrm{H}_{31} \mathrm{NO}_{4} \mathrm{~S}$ 489.1968; found 489.1976 .

\section{ASSOCIATED CONTENT}

\section{Supporting Information}

The Supporting Information is available free of charge at https://pubs.acs.org/doi/10.1021/acs.joc.1c00825.

$$
\text { Copies of }{ }^{1} \mathrm{H} \text { and }{ }^{13} \mathrm{C}\left\{{ }^{1} \mathrm{H}\right\} \text { NMR spectra (PDF) }
$$

\section{AUTHOR INFORMATION}

\section{Corresponding Authors}

Enrique Gómez-Bengoa - Departamento de Química Orgánica I, Universidad del País Vasco UPV/EHU, 20009 Donostia-San, Sebastián; ㅈorcid.org/0000-0002-87533760; Email: enrique.gomez@ehu.es

José Pérez Sestelo - Centro de Investigacións Científicas Avanzadas (CICA) and Departamento de Química, Universidade da Coruña, E-15071 A Coruña, Spain; ○ orcid.org/0000-0001-7036-6217; Email: sestelo@udc.es

\section{Authors}

Ramón E. Millán - Centro de Investigacións Científicas Avanzadas (CICA) and Departamento de Química, Universidade da Coruña, E-15071 A Coruña, Spain

Jaime Rodríguez - Centro de Investigacións Científicas Avanzadas (CICA) and Departamento de Química, Universidade da Coruña, E-15071 A Coruña, Spain; (1) orcid.org/0000-0001-5348-6970

Luis A. Sarandeses - Centro de Investigacións Científicas Avanzadas (CICA) and Departamento de Química, Universidade da Coruña, E-15071 A Coruña, Spain; (1) orcid.org/0000-0003-1114-7107

Complete contact information is available at: https://pubs.acs.org/10.1021/acs.joc.1c00825

\section{Notes}

The authors declare no competing financial interest.

\section{ACKNOWLEDGMENTS}

Dedicated to the memory of Prof. Kilian Muñiz. We thank the Spanish Ministerio de Ciencia, Innovación y Universidades (PGC2018-097792-B-I00 and PID 2019-110008GB-I00), Xunta de Galicia (GRC2018/039), IZO-SGI SGIker of UPV/ $\mathrm{EHU}$, and EDRF funds for financial and human support. 


\section{REFERENCES}

(1) (a) Ye, F.; Ge, Y.; Spannenberg, A.; Neumann, H.; Beller, M. The Role of Allyl Ammonium Salts in Palladium-Catalyzed Cascade Reactions Towards the Synthesis of Spiro-Fused Heterocycles. Nat. Commun. 2020, 11, No. 5383. and references therein. (b) Catalytic Cascade Reactions; Xu, P. F.; Wang, W., Eds; Wiley: Hoboken, New Jersey, 2014.

(2) For some reviews see: (a) Barrett, A. G. M.; Ma, T.-K.; Mies, T. Recent Developments in Polyene Cyclizations and Their Applications in Natural Product Synthesis. Synthesis 2019, 51, 67-82. (b) Wendt, K. U.; Schulz, G. E.; Corey, E. J.; Liu, D. R. Enzyme Mechanisms for Polycyclic Triterpene Formation. Angew. Chem., Int. Ed. 2000, 39, 2812-2833. (c) Yoder, R. A.; Johnston, J. N. A Case Study in Biomimetic Total Synthesis: Polyolefin Carbocyclizations to Terpenes and Steroids. Chem. Rev. 2005, 105, 4730-4756.

(3) Representative examples: (a) Corey, E. J.; Lee, J. Enantioselective Total Synthesis of Oleanolic Acid, Erythrodiol, $\beta$-Amyrin, and Other Pentacyclic Triterpenes From a Common Intermediate. J. Am. Chem. Soc. 1993, 115, 8873-8874. (b) Corey, E. J.; Lin, S. A Short Enantioselective Total Synthesis of Dammarenediol II. J. Am. Chem. Soc. 1996, 118, 8765-8766. (c) Huang, A. X.; Xiong, Z.; Corey, E. J. An Exceptionally Short and Simple Enantioselective Total Synthesis of Pentacyclic Triterpenes of the $\beta$-Amyrin Family. J. Am. Chem. Soc. 1999, 121, 9999-10003. (d) Surendra, K.; Corey, E. J. Rapid and Enantioselective Synthetic Approaches to Germanicol and Other Pentacyclic Triterpenes. J. Am. Chem. Soc. 2008, 130, 8865-8869. (e) Surendra, K.; Corey, E. J. A Short Enantioselective Total Synthesis of the Fundamental Pentacyclic Triterpene Lupeol. J. Am. Chem. Soc. 2009, 131, 13928-13929. (f) Bartels, F.; Hong, Y. J.; Ueda, D.; Weber, M.; Sato, T.; Tantillo, D. J.; Christmann, M. Bioinspired Synthesis of Pentacyclic Onocerane Triterpenoids. Chem. Sci. 2017, 8, 8285-8290.

(4) (a) Fürstner, A.; Davies, P. W. Catalytic Carbophilic Activation: Catalysis by Platinum and Gold $\pi$ Acids. Angew. Chem., Int. Ed. 2007, $46,3410-3449$. (b) Yamamoto, Y. From $\sigma$ - to $\pi$-Electrophilic Lewis Acids. Application to Selective Organic Transformations. J. Org. Chem. 2007, 72, 7817-7831. (c) Sethofer, S. G.; Mayer, T.; Toste, F. D. Gold(I)-Catalyzed Enantioselective Polycyclization Reactions. J. Am. Chem. Soc. 2010, 132, 8276-8277.

(5) For recent key feature article, see: (a) Ríos, P.; Rodríguez, A.; Conejero, S. Enhancing the Catalytic Properties of Well-Defined Electrophilic Platinum Complexes. Chem. Commun. 2020, 56, 53335349. Some representative references: (b) Chatani, N.; Furukawa, N.; Sakurai, H.; Murai, S. $\mathrm{PtCl}_{2}$-Catalyzed Conversion of 1,6- and 1,7Enynes to 1-Vinylcycloalkenes. Anomalous Bond Connection in Skeletal Reorganization of Enynes. Organometallics 1996, 15, 901903. (c) Oi, S.; Tsukamoto, I.; Miyano, S.; Inoue, Y. Cationic PlatinumComplex-Catalyzed Skeletal Reorganization of Enynes. Organometallics 2001, 20, 3704-3709. (d) Fürstner, A. From Understanding to Prediction: Gold- and Platinum-Based $\Pi$-Acid Catalysis for Target Oriented Synthesis. Acc. Chem. Res. 2014, 47, 925-938. (e) Geier, M. J.; Gagné, M. R. Diastereoselective Pt Catalyzed Cycloisomerization of Polyenes to Polycycles. J. Am. Chem. Soc. 2014, 136, 3032-3035. (f) Toullec, P. Y.; Michelet, V. Chiral Cationic Platinum Complexes: New Catalysts for the Activation of Carbon-Carbon Multiple Bonds Towards Nucleophilic Enantioselective Attack. Curr. Org. Chem. 2010, 14, 1245-1253. (g) Mascareñas, J. L.; Varela, I.; López, F. Allenes and Derivatives in Gold(I)- and Platinum(II)-Catalyzed Formal Cycloadditions. Acc. Chem. Res. 2019, 52, 465-479.

(6) For some leading references, see: (a) Zhang, L.; Kozmin, S. A. Gold-Catalyzed Assembly of Heterobicyclic Systems. J. Am. Chem. Soc. 2005, 127, 6962-6963. (b) Lim, C.; Kang, J.-E.; Lee, J.-E.; Shin, S. Gold-Catalyzed Tandem $\mathrm{C}-\mathrm{C}$ and $\mathrm{C}-\mathrm{O}$ Bond Formation: A Highly Diastereoselective Formation of Cyclohex-4-ene-1,2-diol Derivatives. Org. Lett. 2007, 9, 3539-3542. (c) Fürstner, A. Gold and Platinum Catalysis-a Convenient Tool for Generating Molecular Complexity. Chem. Soc. Rev. 2009, 38, 3208-3221. (d) Dorel, R.; Echavarren, A. M. Gold(I)-Catalyzed Activation of Alkynes for the Construction of Molecular Complexity. Chem. Rev. 2015, 115, 9028-9072. (e) Li, Y.; Li, W.; Zhang, J. Gold-Catalyzed Enantioselective Annulations. Chem.
- Eur. J. 2017, 23, 467-512. (f) Marín-Luna, M.; Nieto Faza, O.; Silva López, C. Gold-Catalyzed Homogeneous (Cyclo)isomerization Reactions. Front. Chem. 2019, 7, 296. (g) Virumbrales, C.; SuárezPantiga, S.; Marín-Luna, M.; Silva López, C.; Sanz, R. Unlocking the 5exo Pathway with the $\mathrm{Au}^{\mathrm{I}}$-Catalyzed Alkoxycyclization of 1,3-Dien-5ynes. Chem. - Eur. J. 2020, 26, 8443-8451. (h) Mies, T.; White, A. J. P.; Parsons, P. J.; Barrett, A. G. M. Biomimetic Syntheses of Analogs of Hongoquercin A and B by Late-Stage Derivatization. J. Org. Chem. 2021, 86, 1802-1817.

(7) (a) Chatani, N.; Inoue, H.; Kotsuma, T.; Murai, S. Skeletal Reorganization of Enynes to 1-Vinylcycloalkenes Catalyzed by $\mathrm{GaCl}_{3}$.J. Am. Chem. Soc. 2002, 124, 10294-10295. (b) Tang, S.; Monot, J.; ElHellani, A.; Michelet, B.; Guillot, R.; Bour, C.; Gandon, V. Cationic Gallium(III) Halide Complexes: a New Generation of $\pi$-Lewis Acids. Chem. - Eur. J. 2012, 18, 10239-10243. (c) Strom, K. R.; Impastato, A. C.; Moy, K. J.; Landreth, A. J.; Snyder, J. K. Gallium(III)-Promoted Halocyclizations of 1,6-Diynes. Org. Lett. 2015, 17, 2126-2129.

(8) (a) Kita, Y.; Yata, T.; Nishimoto, Y.; Chiba, K.; Yasuda, M. Selective Oxymetalation of Terminal Alkynes Via 6-endo Cyclization: Mechanistic Investigation and Application to the Efficient Synthesis of 4-Substituted Isocoumarins. Chem. Sci. 2018, 9, 6041-6052. (b) Kang, K.; Nishimoto, Y.; Yasuda, M. Regio- and Stereoselective Carboindation of Internal Alkynyl Ethers with Organosilicon or -Stannane Nucleophiles. J. Org. Chem. 2019, 84, 13345-13363. (c) Tani, T.; Sohma, Y.; Tsuchimoto, T. Zinc/Indium Bimetallic Lewis Acid Relay Catalysis for Dehydrogenative Silylation/Hydrosilylation Reaction of Terminal Alkynes with Bis(hydrosilane)s. Adv. Synth. Catal. 2020, 362, 4098-4108. (d) Vayer, M.; Bour, C.; Gandon, V. Exploring the Versatility of 7-Alkynylcycloheptatriene Scaffolds Under $\pi$-Acid Catalysis. Eur. J. Org. Chem. 2020, 2020, 5350-5357. (e) Tian, J.; Chen, Y.; Vayer, M.; Djurovic, A.; Guillot, R.; Guermazi, R.; Dagorne, S.; Bour, C.; Gandon, V. Exploring the Limits of $\pi$-Acid Catalysis Using Strongly Electrophilic Main Group Metal Complexes: the Case of Zinc and Aluminium. Chem. - Eur. J. 2020, 26, 12831-12838.

(9) For some revisions see: (a) Augé, J.; Lubin-Germain, N.; Uziel, J. Recent Advances in Indium-Promoted Organic Reactions. Synthesis 2007, 2007, 1739-1764. (b) Pathipati, S. R.; van der Werf, A.; Selander, N. Indium(III)-Catalyzed Transformations of Alkynes: Recent Advances in Carbo- and Heterocyclization Reactions. Synthesis 2017, 49, 4931-4941. (c) Sestelo, J. P.; Sarandeses, L. A.; Martínez, M. M.; Alonso-Marañón, L. Indium(III) as $\pi$-Acid Catalyst for the Electrophilic Activation of Carbon-Carbon Unsaturated Systems. Org. Biomol. Chem. 2018, 16, 5733-5747.

(10) Araki, S.; Hirashita, T. Comprehensive Organometallic Chemistry III; Crabtree, R. H.; Mingos, D. M. P., Eds.; Elsevier: Oxford, 2007; Vol. 9, pp 649-722.

(11) (a) Cintas, P. Synthetic Organoindium Chemistry: What Makes Indium So Appealing? Synlett 1995, 1995, 1087-1096. (b) Frost, C. G.; Hartley, J. P. New Applications of Indium Catalysts in Organic Synthesis. Mini-Rev. Org. Chem. 2004, 1, 1-7. (c) Fringuelli, F.; Piermatti, O.; Pizzo, F.; Vaccaro, L. Indium Salt-Promoted Organic Reactions. Curr. Org. Chem. 2003, 7, 1661-1689. (d) Yadav, J. S.; Antony, A.; George, J.; Subba Reddy, B. V. Recent Developments in Indium Metal and Its Salts in Organic Synthesis. Eur. J. Org. Chem. 2010, 2010, 591-605. (f) Singh, M. S.; Raghuvanshi, K. Recent Advances in $\mathrm{InCl}_{3}$-Catalyzed One-Pot Organic Synthesis. Tetrahedron 2012, 68, 8683-8697.

(12) For representative examples, see: (a) Mamane, V.; Hannen, P.; Fürstner, A. Synthesis of Phenanthrenes and Polycyclic Heteroarenes by Transition-Metal Catalyzed Cycloisomerization Reactions. Chem. Eur. J. 2004, 10, 4556-4575. (b) Nishimoto, Y.; Moritoh, R.; Yasuda, M.; Baba, A. Regio- and Stereoselective Generation of Alkenylindium Compounds From Indium Tribromide, Alkynes, and Ketene Silyl Acetals. Angew. Chem., Int. Ed. 2009, 48, 4577-4580. (c) Antoniotti, S.; Dalla, V.; Duñach, E. Metal Triflimidates: Better Than Metal Triflates as Catalysts in Organic Synthesis-the Effect of a Highly Delocalized Counteranion. Angew. Chem., Int. Ed. 2010, 49, 7860-7888. (d) Tsuchimoto, T.; Kanbara, M. Reductive Alkylation of Indoles with Alkynes and Hydrosilanes Under Indium Catalysis. Org. Lett. 
2011, 13, 912-915. (e) Kumar, A.; Li, Z.; Sharma, S. K.; Parmar, V. S.; Van der Eycken, E. V. Switching the Regioselectivity via Indium(III) and Gold(I) Catalysis: a Post-Ugi Intramolecular Hydroarylation to Azepino- and Azocino-[c,d]indolones. Chem. Commun. 2013, 49, 6803-6805. (f) Michelet, B.; Colard-Itte, J.-R.; Thiery, G.; Guillot, R.; Bour, C.; Gandon, V. Dibromoindium(III) Cations as a $\pi$-Lewis Acid: Characterization of $\left[\mathrm{IPr} \cdot \mathrm{InBr}_{2}\right]\left[\mathrm{SbF}_{6}\right]$ and Its Catalytic Activity Towards Alkynes and Alkenes. Chem. Commun. 2015, 51, 74017404. (g) Yonekura, K.; Yoshimura, Y.; Akehi, M.; Tsuchimoto, T. A Heteroarylamine Library: Indium-Catalyzed Nucleophilic Aromatic Substitution of Alkoxyheteroarenes with Amines. Adv. Synth. Catal. 2018, 360, 1159-1181. (h) de Orbe, M. E.; Zanini, M.; Quinonero, O.; Echavarren, A. M. Gold- or Indium-Catalyzed Cross-Coupling of Bromoalkynes with Allylsilanes Through a Concealed Rearrangement. ACS Catal. 2019, 9, 7817-7822.

(13) For some reviews see: (a) Echavarren, A. M.; Nevado, C. NonStabilized Transition Metal Carbenes as Intermediates in Intramolecular Reactions of Alkynes with Alkenes. Chem. Soc. Rev. 2004, 33, 431-436. (b) Jiménez-Núñez, E.; Echavarren, A. M. GoldCatalyzed Cycloisomerizations of Enynes: a Mechanistic Perspective. Chem. Rev. 2008, 108, 3326-3350. (c) Toullec, P. Y.; Michelet, V. Cycloisomerization of 1,n-Enynes via Carbophilic Activation. Top. Curr. Chem. 2011, 302, 31-80. (d) Aubert, C.; Fensterbank, L.; Garcia, P.; Malacria, M.; Simonneau, A. Transition Metal Catalyzed Cycloisomerizations of 1,n-Allenynes and -Allenenes. Chem. Rev. 2011, 111, 1954-1993.

(14) (a) Imagawa, H.; Iyenaga, T.; Nishizawa, M. Mercuric TriflateCatalyzed Tandem Cyclization Leading to Polycarbocycles. Org. Lett. 2005, 7, 451-453. (b) Pradal, A.; Chen, Q.; Faudot dit Bel, P.; Toullec, P. Y.; Michelet, V. Gold-Catalyzed Cycloisomerization of Functionalized 1,5-Enynes - an Entry to Polycyclic Framework. Synlett 2012, 2012, 74-79. (c) Rong, Z.; Echavarren, A. M. Broad Scope Gold(I)Catalysed Polyenyne Cyclisations for the Formation of Up to Four Carbon-Carbon Bonds. Org. Biomol. Chem. 2017, 15, 2163-2167. (d) Lu, X.-L.; Lyu, M.-Y.; Peng, X.-S.; Wong, H. N. C. Gold(I)Catalyzed Tandem Cycloisomerization of 1,5-Enyne Ethers by Hydride Transfer. Angew. Chem., Int. Ed. 2018, 57, 11365-11368.

(15) Miyanohana, Y.; Chatani, N. Skeletal Reorganization of Enynes Catalyzed by $\mathrm{InCl}_{3}$. Org. Lett. 2006, 8, 2155-2158.

(16) (a) Surendra, K.; Qiu, W.; Corey, E. J. A Powerful New Construction of Complex Chiral Polycycles by an Indium(III)Catalyzed Cationic Cascade. J. Am. Chem. Soc. 2011, 133, 97249726. (b) Surendra, K.; Corey, E. J. Diiodoindium(III) Cation, $\operatorname{InI}_{2}{ }^{+}$, a Potent Yneophile. Generation and Application to Cationic Cyclization by Selective $\pi$-Activation of $\mathrm{C} \equiv \mathrm{C}$. J. Am. Chem. Soc. 2014, 136, 10918-10920.

(17) For some representative references, see: (a) Pérez, I.; Pérez Sestelo, J.; Sarandeses, L. A. Atom-Efficient Metal-Catalyzed CrossCoupling Reaction of Indium Organometallics with Organic Electrophiles. J. Am. Chem. Soc. 2001, 123, 4155-4160. (b) Caeiro, J.; Pérez Sestelo, J.; Sarandeses, L. A. Enantioselective Nickel-Catalyzed CrossCoupling Reactions of Trialkynylindium Reagents with Racemic Secondary Benzyl Bromides. Chem. - Eur. J. 2008, 14, 741-746. (c) Mato, M.; Pérez-Caaveiro, C.; Sarandeses, L. A.; Pérez Sestelo, J. Ferrocenylindium Reagents in Palladium-Catalyzed Cross-Coupling Reactions: Asymmetric Synthesis of Planar Chiral 2-Aryl Oxazolyl and Sulfinyl Ferrocenes. Adv. Synth. Catal. 2017, 359, 1388-1393. (d) GilNegrete, J. M.; Pérez Sestelo, J.; Sarandeses, L. A. Synthesis of BenchStable Solid Triorganoindium Reagents and Reactivity in PalladiumCatalyzed Cross-Coupling Reactions. Chem. Commun. 2018, 54, 14531456. (e) Gil-Negrete, J. M.; Pérez Sestelo, J.; Sarandeses, L. A. Transition-Metal-Free Oxidative Cross-Coupling of Triorganoindium Reagents with Tetrahydroisoquinolines. J. Org. Chem. 2019, 84, 97789785.

(18) (a) Alonso-Marañón, L.; Martínez, M. M.; Sarandeses, L. A.; Pérez Sestelo, J. Indium-Catalyzed Intramolecular Hydroarylation of Aryl Propargyl Ethers. Org. Biomol. Chem. 2015, 13, 379-387. (b) Alonso-Marañón, L.; Sarandeses, L. A.; Martínez, M. M.; Pérez Sestelo, J. Sequential In-Catalyzed Intramolecular Hydroarylation and
Pd-Catalyzed Cross-Coupling Reactions Using Bromopropargyl Aryl Ethers and Amines. Org. Chem. Front. 2017, 4, 500-505. (c) AlonsoMarañón, L.; Sarandeses, L. A.; Martínez, M. M.; Pérez Sestelo, J. Synthesis of Fused Chromenes by the Indium(III)-Catalyzed Cascade Hydroarylation/Cycloisomerization Reactions of Polyyne-Type Aryl Propargyl Ethers. Org. Chem. Front. 2018, 5, 2308-2312. (d) AlonsoMarañón, L.; Martínez, M. M.; Sarandeses, L. A.; Gómez-Bengoa, E.; Pérez Sestelo, J. Indium(III)-Catalyzed Synthesis of Benzo[b]Furans by Intramolecular Hydroalkoxylation of ortho-Alkynylphenols: Scope and Mechanistic Insights. J. Org. Chem. 2018, 83, 7970-7980.

(19) Using ${ }^{1} \mathrm{H}-{ }^{1} \mathrm{H}$ COSY, edited-HSQC and HMBC experiments, we were able to assign all protons and carbons for (trans)-4f. Key signals to deduce the trans-fused bicyclic system were protons $\mathrm{H}-6\left(\delta_{\mathrm{H}} 2.21 \mathrm{ppm}\right.$, $\mathrm{td}, J=11.2,11.2,2.2 \mathrm{~Hz})$ and $\mathrm{H}-5\left(\delta_{\mathrm{H}} 2.02 \mathrm{ppm}, \mathrm{bt}, J=11.5 \mathrm{~Hz}\right)$, which clearly show an antiperiplanar relationship between them (see the SI on page S40-S42).

(20) Toullec, P. Y.; Blarre, T.; Michelet, V. Mimicking Polyolefin Carbocyclization Reactions: Gold-Catalyzed Intramolecular Phenoxycyclization of 1,5-Enynes. Org. Lett. 2009, 11, 2888-2891.

(21) Capon, R. J. Studies in Natural Products Chemistry; Rahman, A.-u., Ed.; Elsevier: New York, 1995; Vol. 15, pp 289-326.

(22) (a) Shen, Z.-L.; Wang, S.-Y.; Chok, Y.-K.; Xu, Y.-H.; Loh, T.-P. Organoindium Reagents: the Preparation and Application in Organic Synthesis. Chem. Rev. 2013, 113, 271-401. (b) Zhao, K.; Shen, L.; Shen, Z.-L.; Loh, T.-P. Transition Metal-Catalyzed Cross-Coupling Reactions Using Organoindium Reagents. Chem. Soc. Rev. 2017, 46, $586-602$.

(23) Sotorríos, L.; Demertzidou, V. P.; Zografos, A. L.; GómezBengoa, E. DFT Studies on Metal-Catalyzed Cycloisomerization of trans-1,5-Enynes to Cyclopropane Sesquiterpenoids. Org. Biomol. Chem. 2019, 17, 5112-5120.

(24) All structures were optimized using Gaussian 16 with the B3LYP/6-31G(d,p) method for C, H, and O and SDD basis set for In and I. Final energies were refined at the M06/def2tzvpp level of theory in toluene. For more details, see the Supporting Information.

(25) Surendra, K.; Rajendar, G.; Corey, E. J. Useful Catalytic Enantioselective Cationic Double Annulation Reactions Initiated at an Internal $\pi$-Bond: Method and Applications. J. Am. Chem. Soc. 2014, 136, 642-645.

(26) Corey, E. J.; Seibel, W. L. First stekeospecific synthesis of E- $\gamma$ bisabolene. A method for the concurrent generation of a ring and a tetrasubstituted exocyclic double bond. Tetrahedron Lett. 1986, 27, 905-908.

(27) Nicolaou, K. C.; Reingruber, R.; Sarlah, D.; Bräse, S. Enantioselective Intramolecular Friedel-Crafts-Type $\alpha$-Arylation of Aldehydes. J. Am. Chem. Soc. 2009, 131, 2086-2087.

(28) Mostafa, M. A. B.; Grafton, M. W.; Wilson, C.; Sutherland, A. A one-pot, three-step process for the diastereoselective synthesis of aminobicyclo[4.3.0] nonanes using consecutive palladium(II)- and ruthenium(II)-catalysis. Org. Biomol. Chem. 2016, 14, 3284-3297. 